\title{
DOCUMENT FALSIFICATION/FORGERY FROM THE VIEW OF ISLAMIC JURISPRUDENCE AND MALAYSIAN LAW
}

\author{
Wan Abdul Fattah Wan Ismail; Ahmad Syukran Baharuddin; \\ Lukman Abdul Mutalib; Muneer Ali Abdul Rabb al-Qubaty \\ Universiti Sains Islam Malaysia, Malaysia \\ email:ahmadsyukran@usim.edu.my
}

\begin{abstract}
Although the scholars of Islamic jurisprudence discussed the importance of document and its strength as a mean of proof, they did not discuss the issue of forgery unless slightly compared with the scholars of law. This is due to its limited extension and uses in the period of times. And with the frequent use of them in our time, the debates have extended towards several circumstances either to attempt for or to deny a forgery. Therefore, this research is conducted to study the document falsification from the perspectives of Islamic Jurisprudence and Malaysian Law. It is also to explain the definition, procedure and methods to identify the crime and its punishment. The study used inductive and content analysis methods on previous scholars' opinions, discussions and explanation from two different legal institutions. This study found the following important results: The are many forms of forgery occur in this era and can be classified either as material or incorporeal fraud. Several implications have been issued against the forgery crime in the Malaysian Penal Code, such as imprisonment, lashes and fines. The Islamic jurisprudence and the Malaysian Evidence Act 1950 has established several methods to verify the validity of documents such as confession, testimony, expert opinion, and oath, but the opinion of the expert is the most important means in verifying the authenticity and originality of documents. This study also found that the Malaysian Evidence Law did
\end{abstract}


not discuss the oath as a mean to verify documents. As analysed, the method to verify documents discussed in the books of jurisprudence is very different from that of the Malaysian Evidence Act 1950, which specifies the conditions of documents and the number of witnesses, but the law does not specify the number of witnesses and impose conditions only.

Meskipun para abli tata hukum Islam membahas pentingnya sebuah dokumen sebagai alat bukti, namun mereka kurang membahas persoalan pemalsuan dokumen sedalam para abli bukum konvensional. Hal ini terkait dengan terbatasnya waktu dan kuantitas penggunaan, sehingga frekuensi penggunaannya memunculkan debat yang panjang, baik yang menerima atau yang menolak soal pemalsuan. Oleh karena itu, artikel ini membahas pemalsuan dokumen dariperspektif tata bukum Islam dan hukum nasional di Malaysia. Artikel ini juga menjelaskan definisi, prosedur, dan metode identiflkasi kejahatan ini serta hukumannya. Penulis menggunakan metode induktif dan analisis isi pada opini, perdebatan, dan penjelasan dari dua institusi bukum yang berbeda. Kajian ini menyimpulkan adanya beragam bentuk pemalsuan dewasa ini, baik material atau non material. Beberapa aturan bukum telah dikeluarkan di Malaysia dan sangsi nya seperti penjara, cambuk dan denda. Peradilan Islam dan Undang Undang Saksi Tabun 1950 telah menetapkan beberapa metode untuk validasi dokumen seperti: pengakuan, testimoni, pendapat abli, dan sumpah, namun pendapat dari abli masib merupakan cara utama untuk verifikasi keautentikan dan keaslian dokumen. Artikel ini juga menemukan bahwa peraturan bukum di Malaysia belum membahas sumpah sebagai alat verifikasi dokumen. Juga metodenya berbeda antara yang ada di dalam buku teks dengan Undang Undang 1950 yang lebih fokus pada kondisi dokumen dan jumlah saksi, padahal di dalam bukumnya tidak memperbitungkan jumlah saksi, hanya kondisinya saja.]

Keywords: Fiqh of Forensics, Forensic Science, Shariah, Al-Qarinah

$$
\text { تالماليزير. الختابة في ضوء الفقه الإسلامي والقانون }
$$




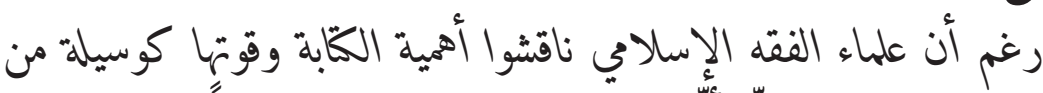

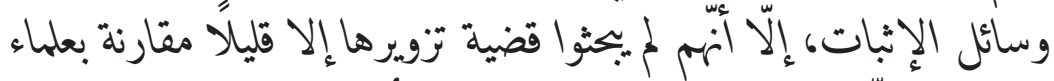

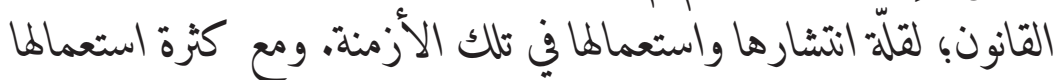

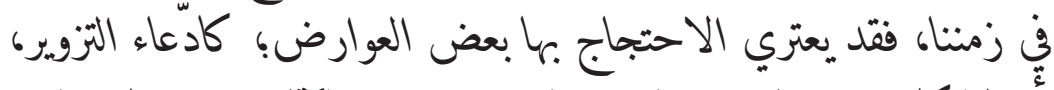

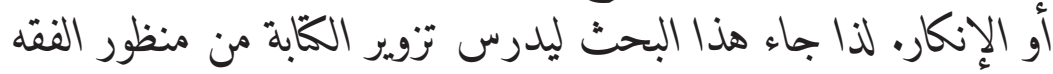

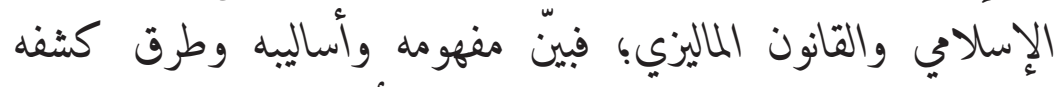

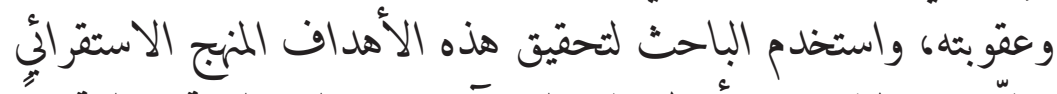

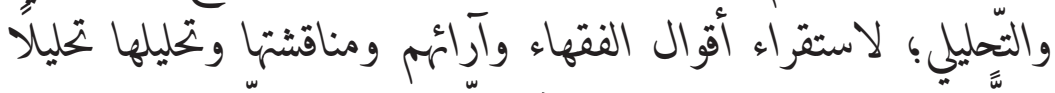

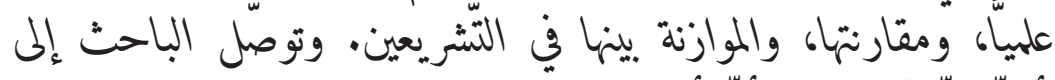

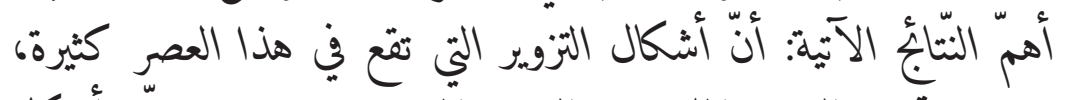

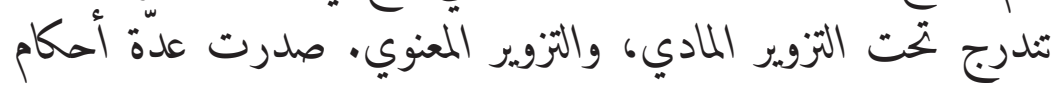

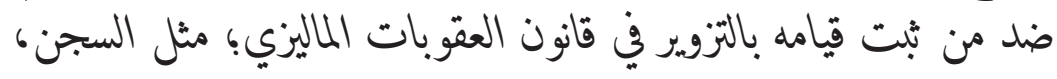

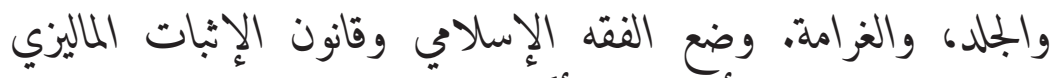

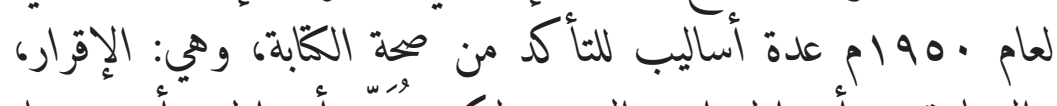

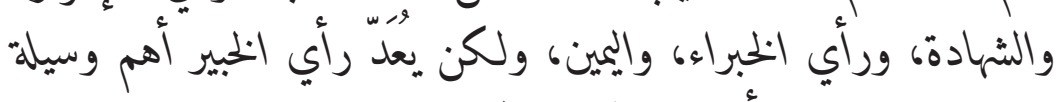

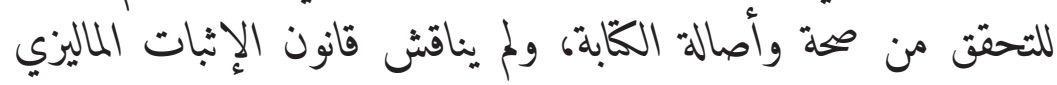

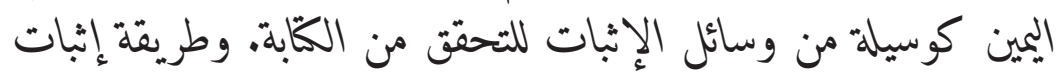

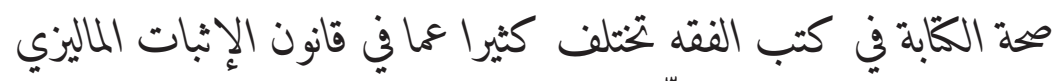

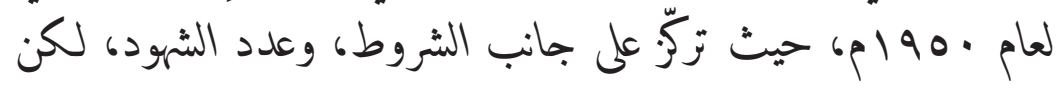
القانون لا يحلد عدد الشهود ويفرض الشروط فقط.

\section{أ. ألمقدمة}

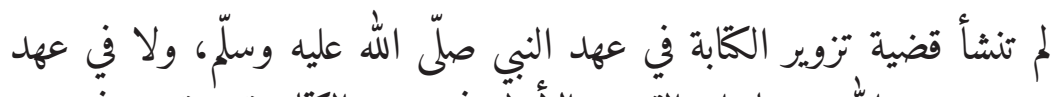

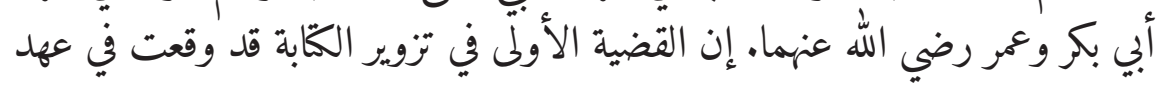




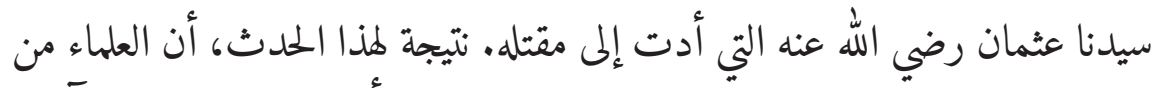

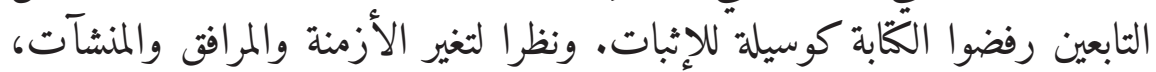

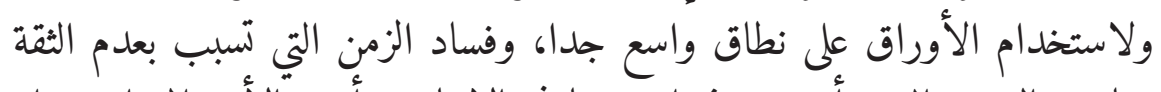

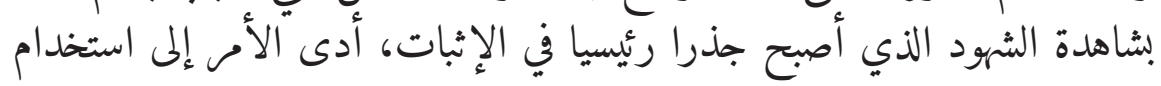

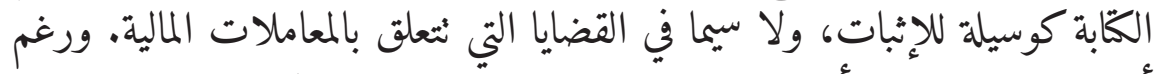

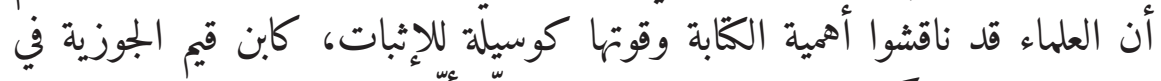

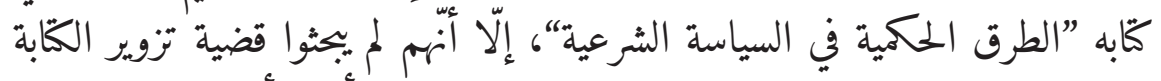

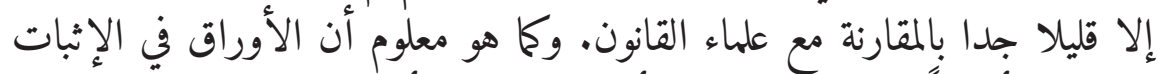

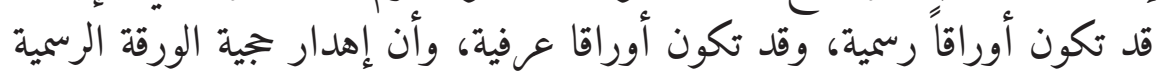

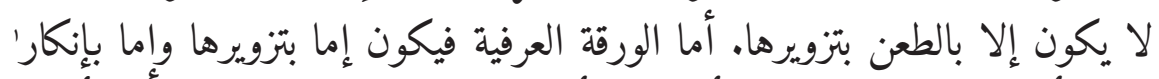

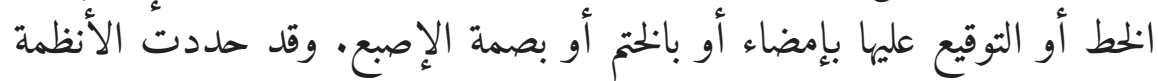

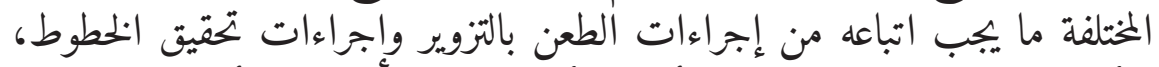

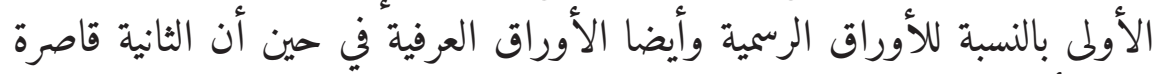
على الأوراق العرفية وحدها.

\section{ب. الأحكام العامة للتزوير في الفقه الإسلامي والقانون الماليزي.}

أن الإنكار يقصد به: "عدم تسليم الخصم بصحة ما هو منسوب إليه من خط أو إمضاء أو بصمة

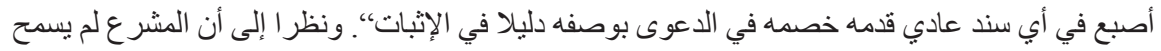

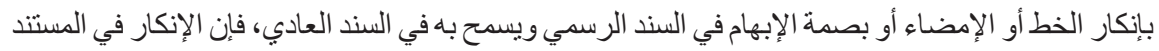

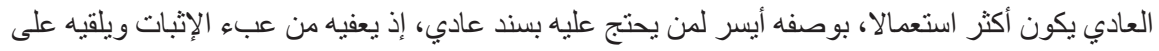

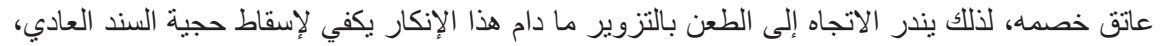

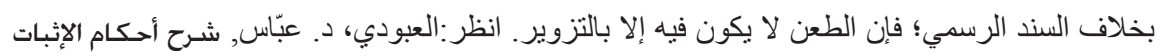

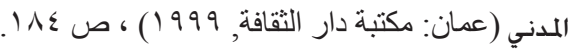

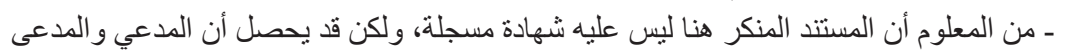

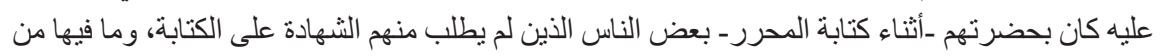

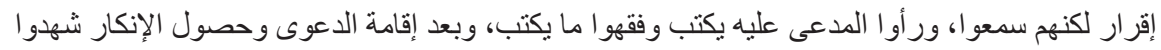

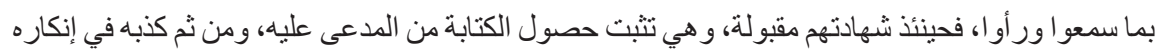

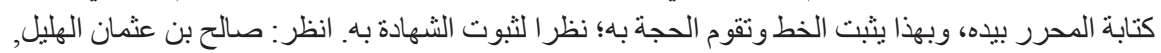

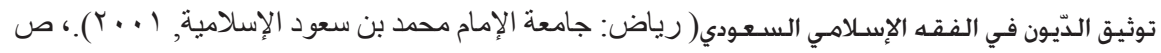

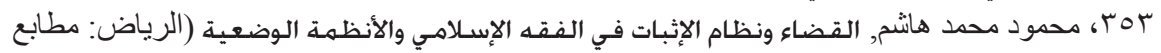

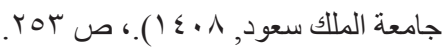




\section{مفهوم التزوير في الفقه الإسلامي.}

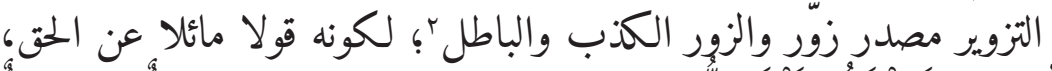

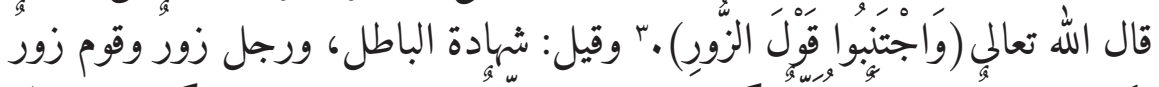

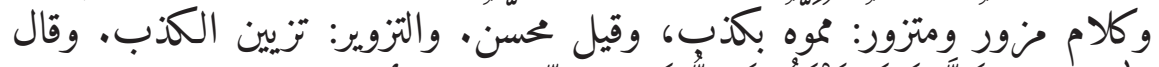

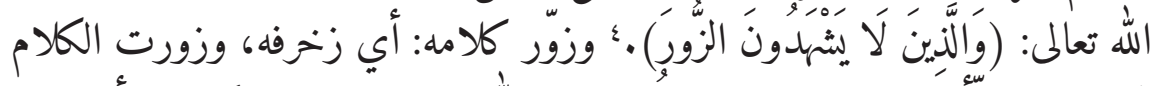

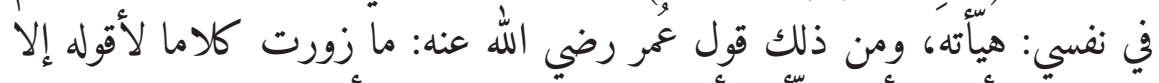

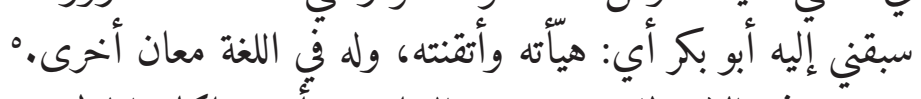

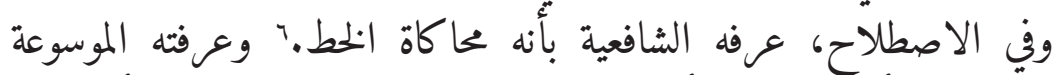

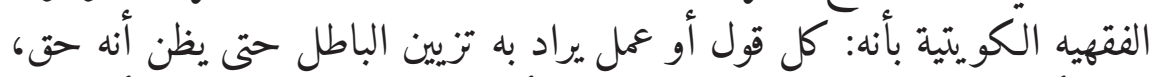

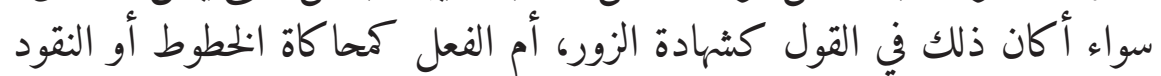

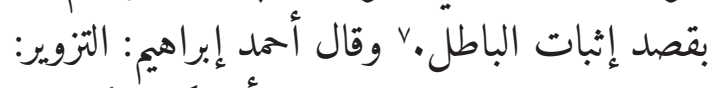

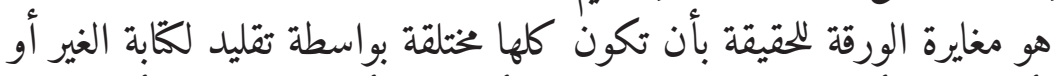

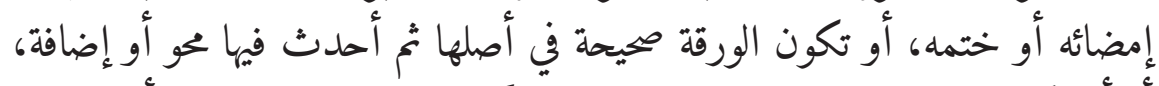

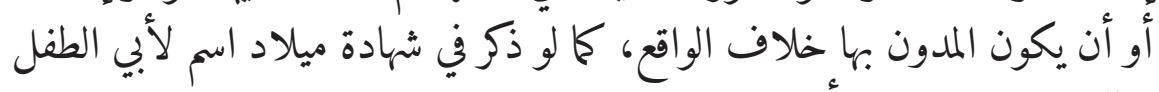
يخالف اسمه الحقيقي، أو أو ألمون

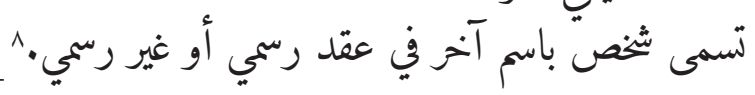

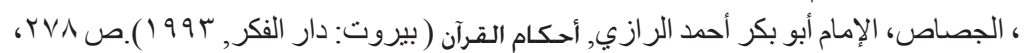
الثير ازي، أبو إسحاق إبر اهيم بن علي بن يوسف الإمان الفيروز آبادي, المهذب في الفي الفقده الإمام الشـافعي(بيروت:

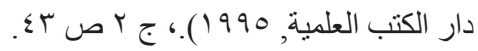

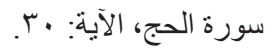

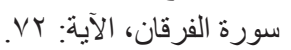

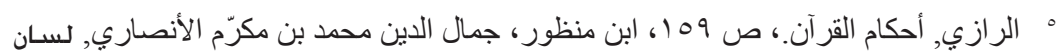

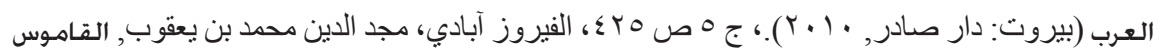

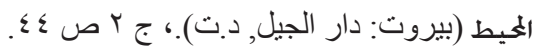

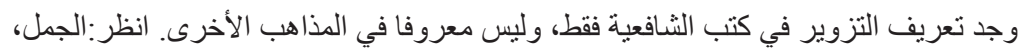

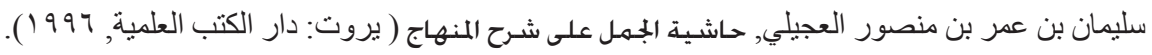

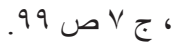
وز ارة الأوقاف و الثؤون الإسلامية, الموسـوعة الفقهية, ع ط. (الكويت: وزارة الأوقاف و الثُؤون

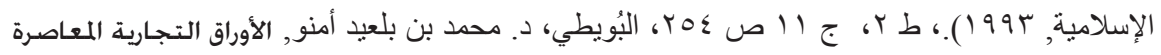

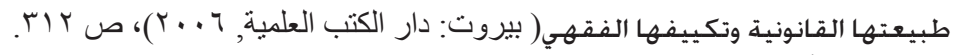

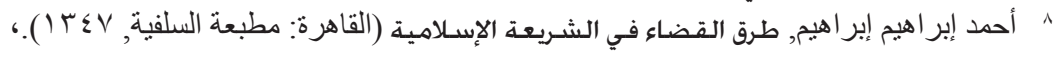




\section{التزوير في القانون الماليزي؟:}

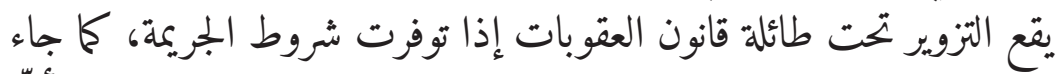

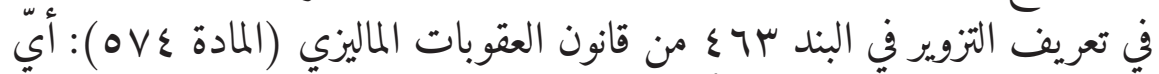

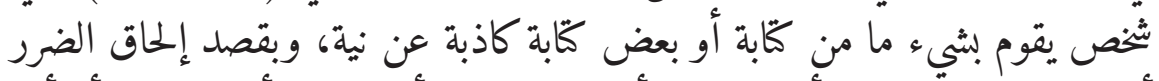

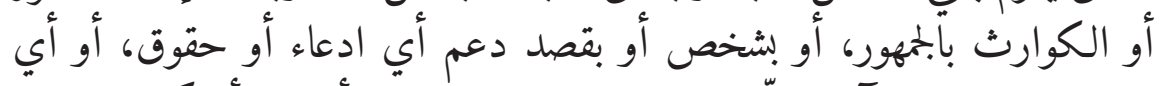

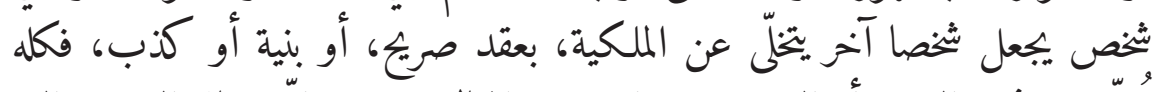

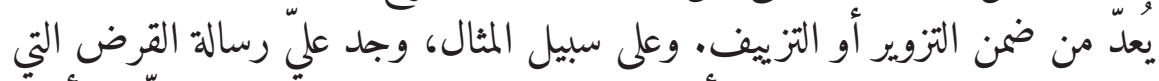

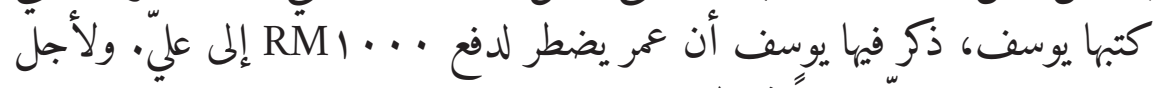

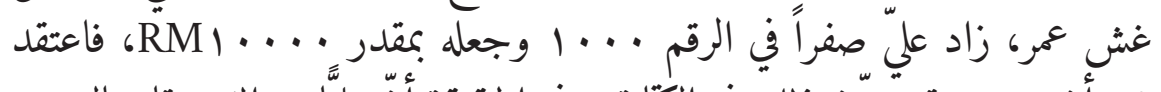

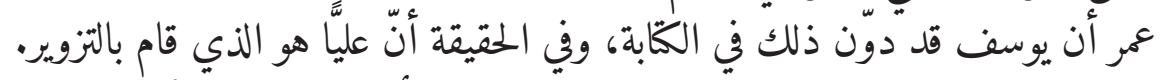

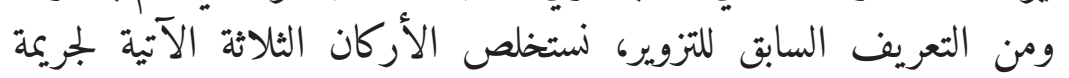

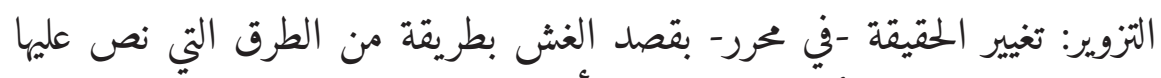

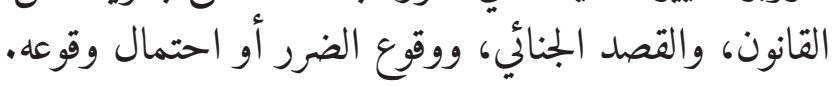

\section{ج• تغيير الحقيقة -في محرر- بقصد الغش بطريقة من الطرق التي نص عليها القانون.}

تغيير الحقيقة جوهر التزويز: التزوير كذب مكتوب، فلا يتصور وقوعه إلا

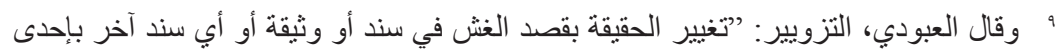

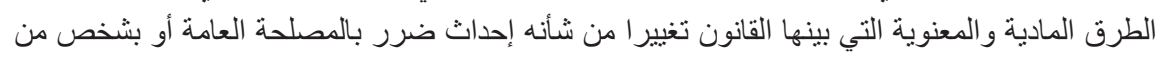

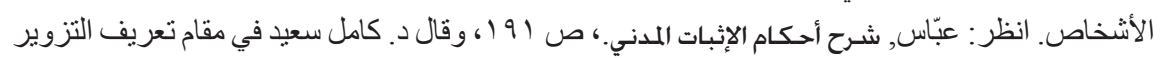

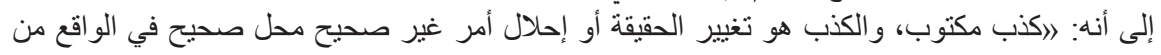

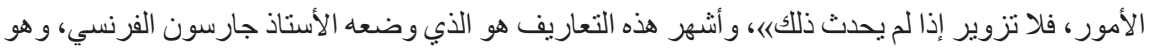

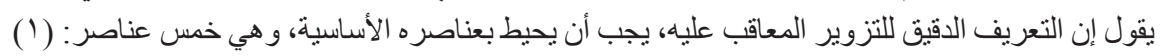

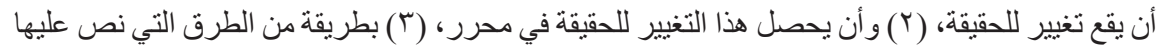

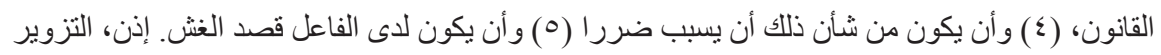

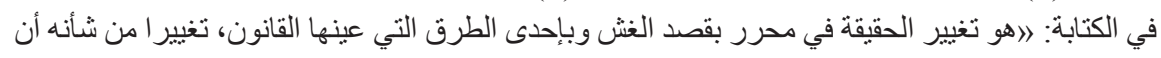

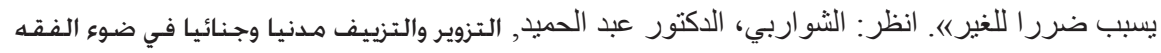

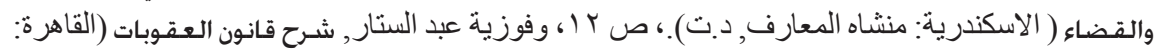

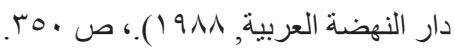


بإبدال الحقيقة بما يخالفها. فإذا لم يحدث تغيير للحقيقة فلا تزوير، حتى ولو كان

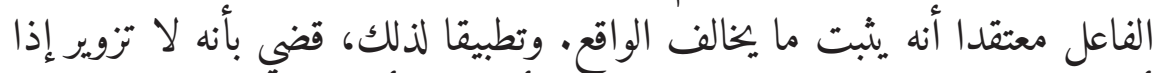

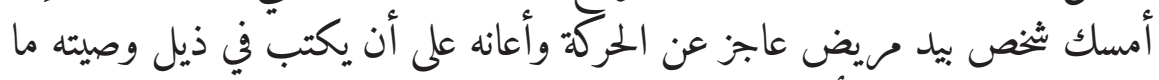

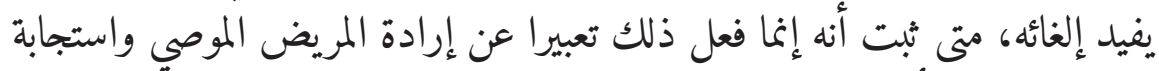

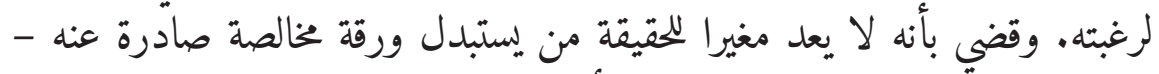

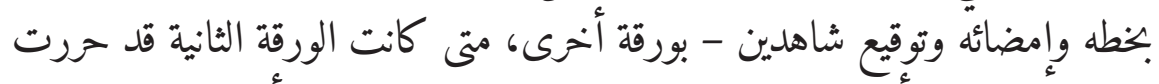

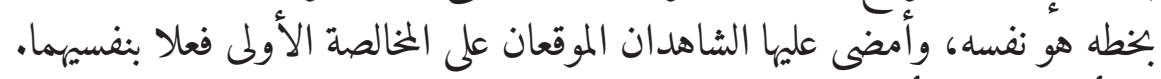

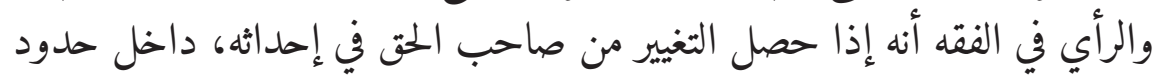
حقه، فلا تزوير.

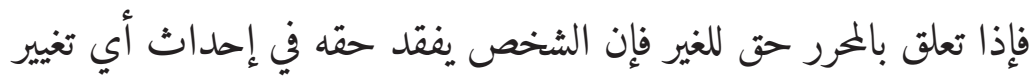

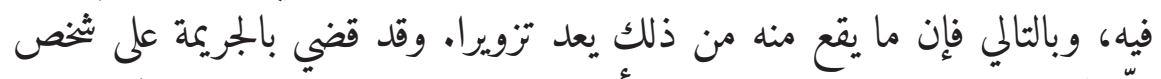

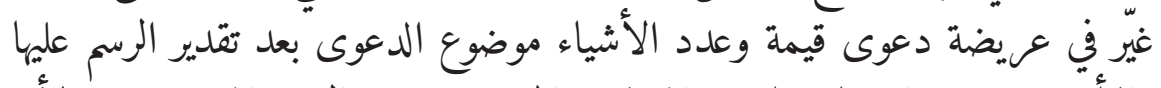

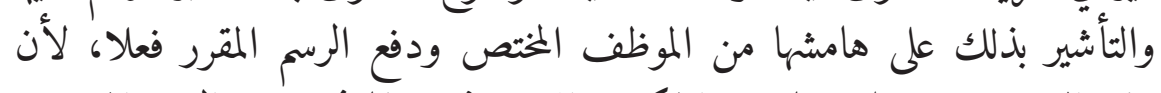

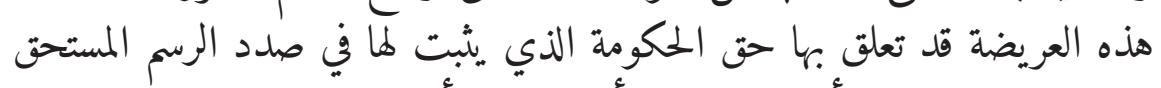

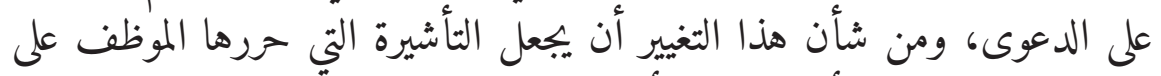

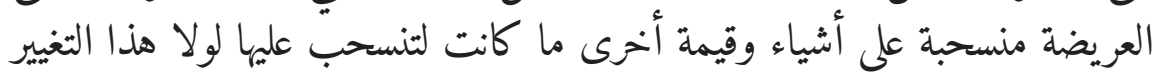
الذي يقتضي رسوما أكثر مما أثبت فيها.

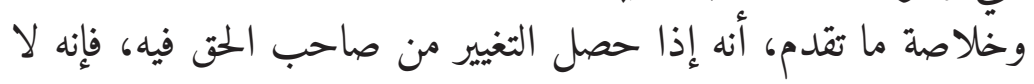

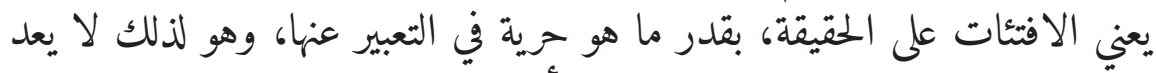

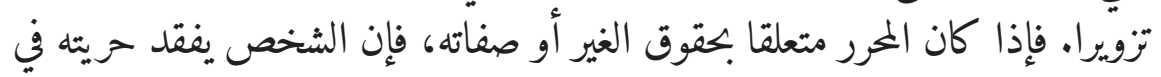

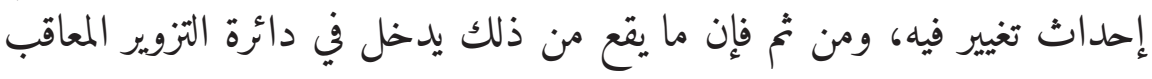

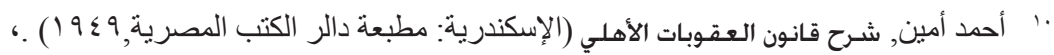

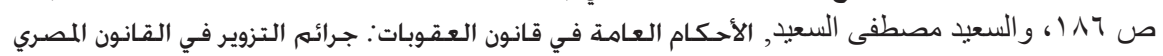

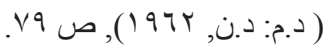

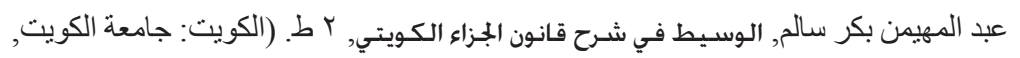




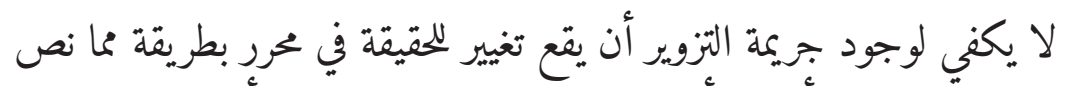

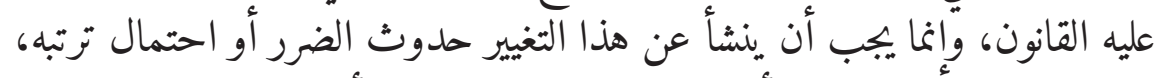

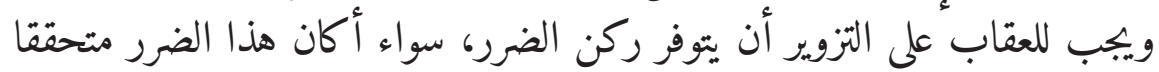

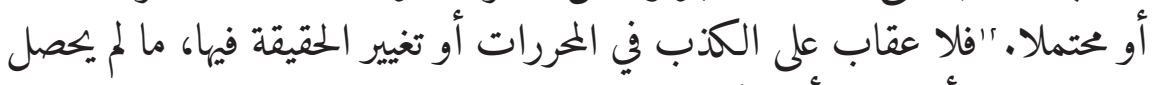

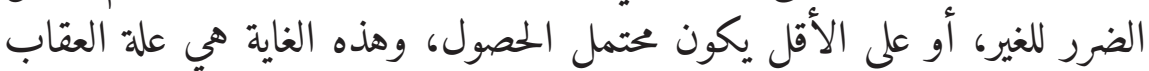

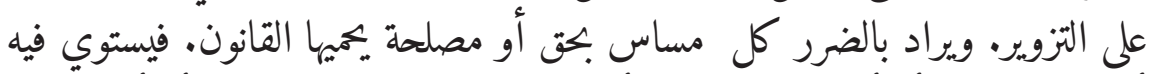

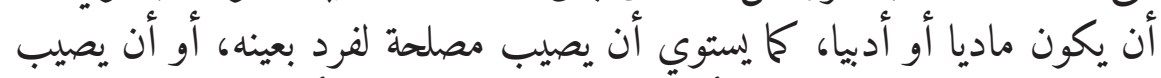

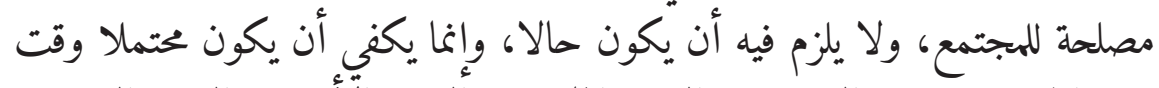

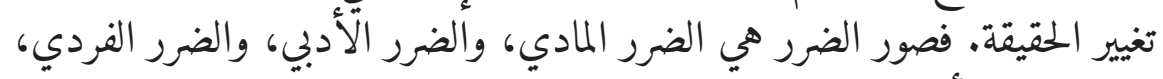

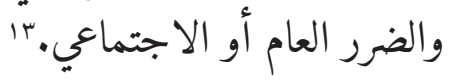

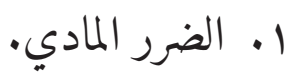

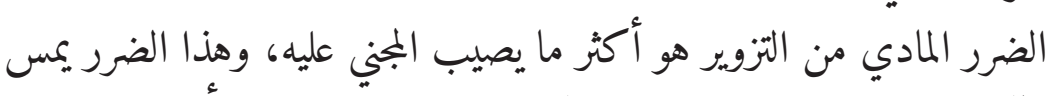

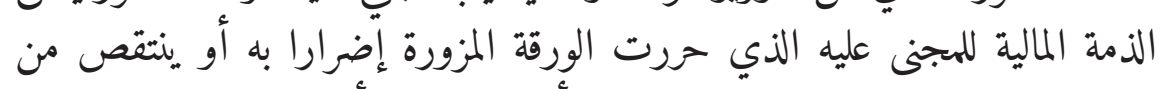

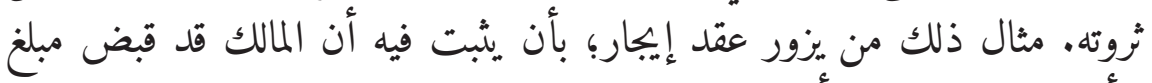

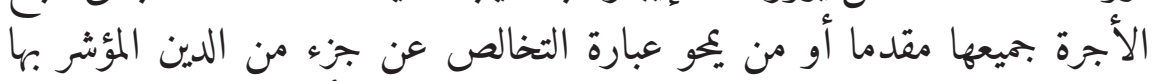

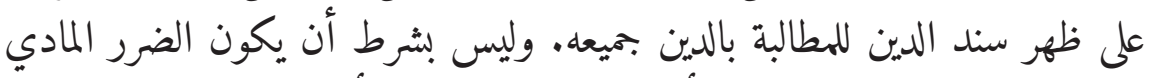

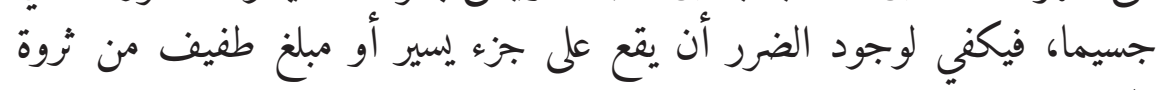

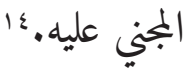

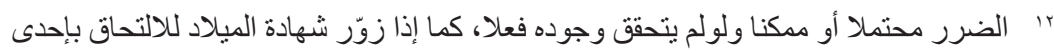

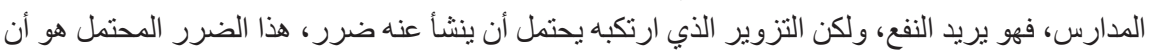

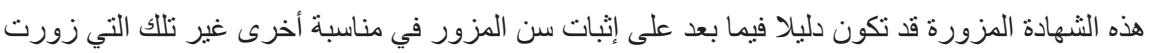

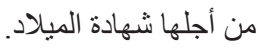

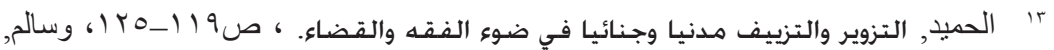

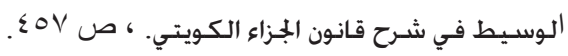

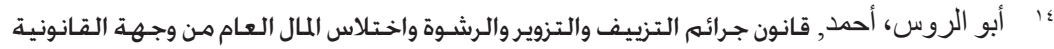

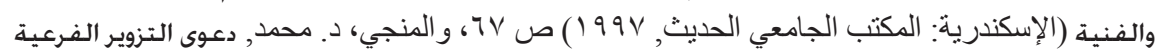

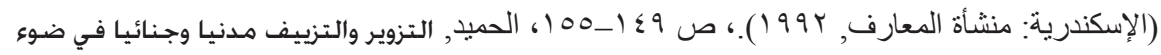




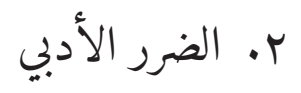

هو الذي لا يصيب المجني عليه في ذمته المالية، وإنما يناله في عرضه وشرفه

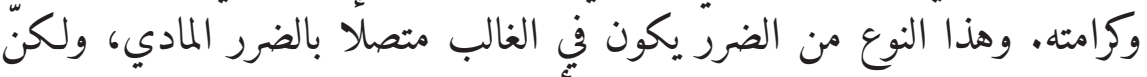

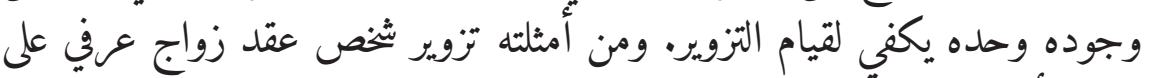

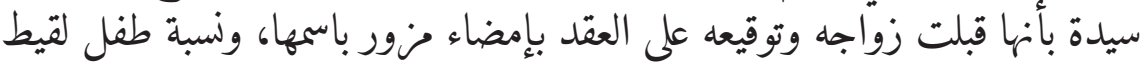

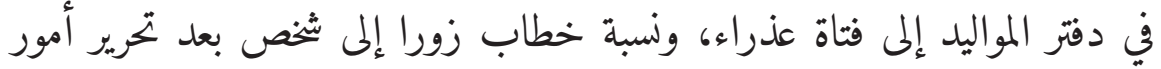

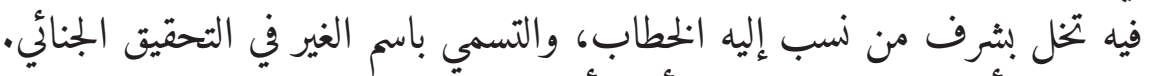

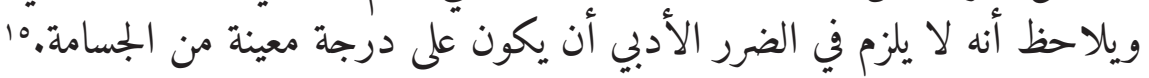

$$
\text { r. الضرر العام أو الاجتماعي }
$$

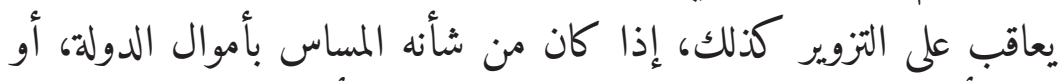

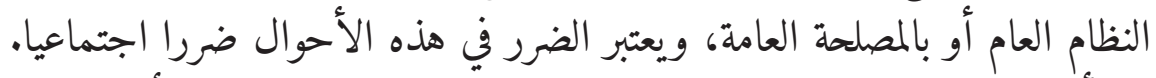

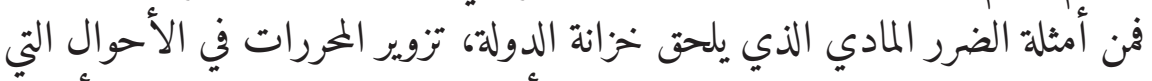

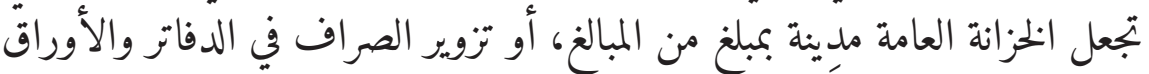

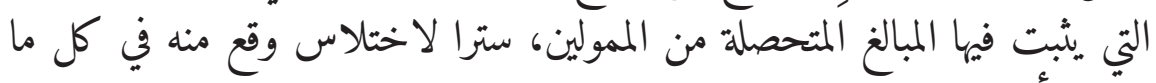
حصله أو بعضه. 17 • - م القصد الجنائي.

عناصر القصد الجنائي اللازم: التزوير جريمة عمدية، فلا يعاقب عليها إلا إذا

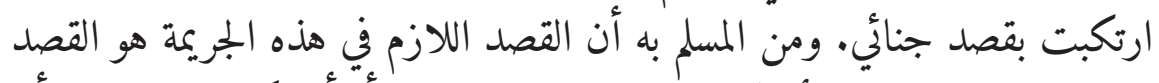

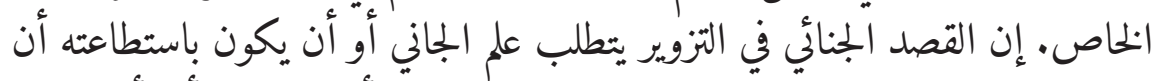

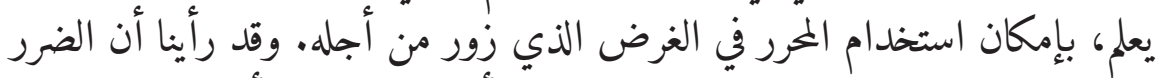

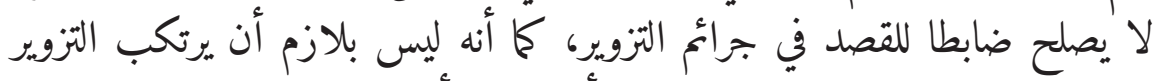

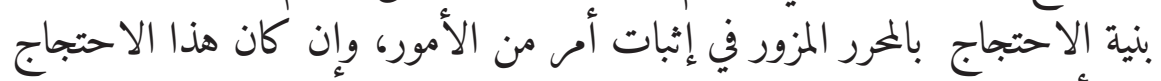

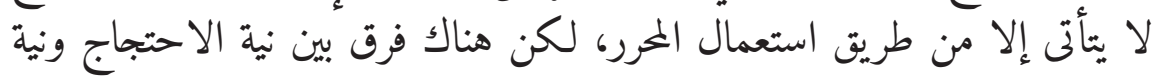

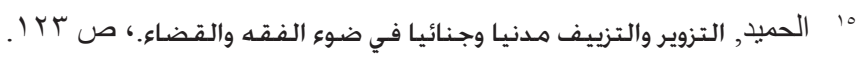

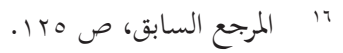


فالاحتجاج فيه معنى التدليل وعنصر الإثبات، أما نية الاستعمال فهي

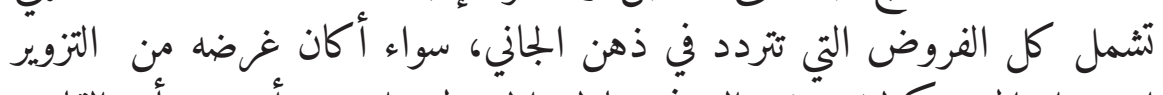

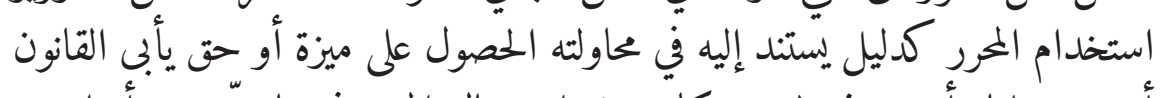

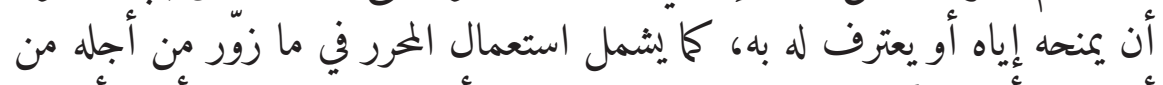

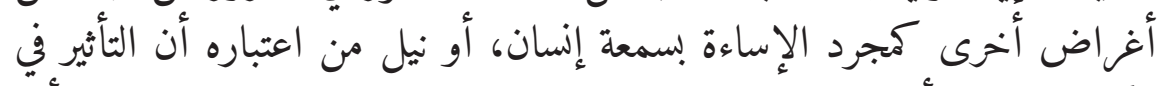

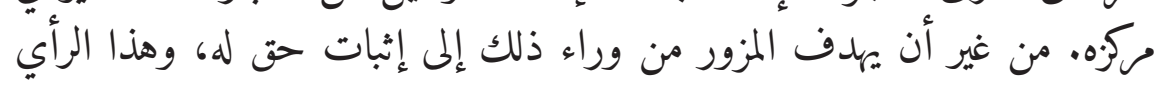

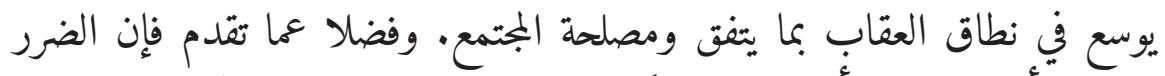

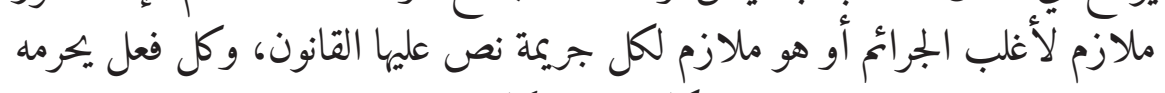

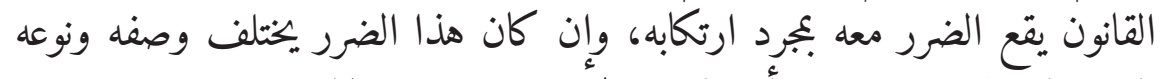

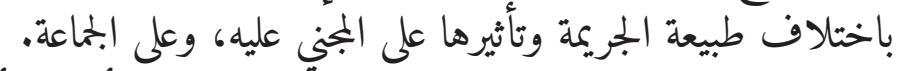

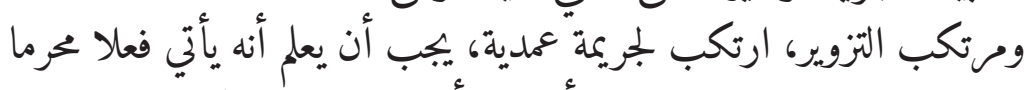

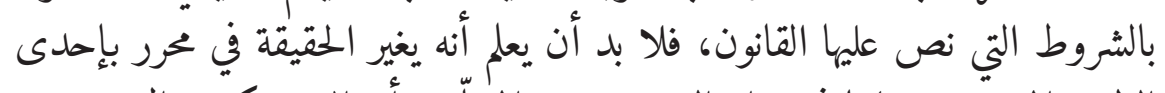

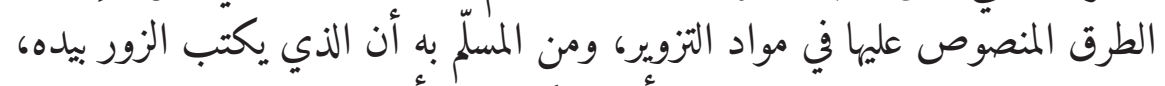

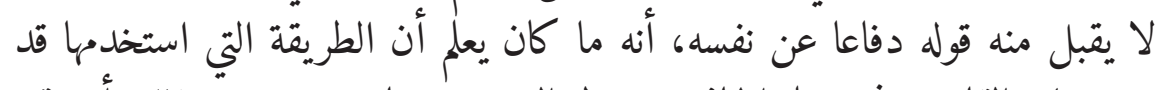

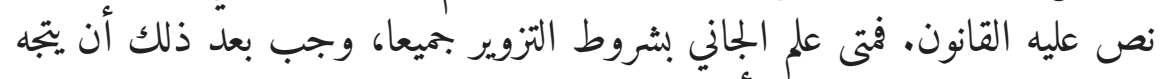

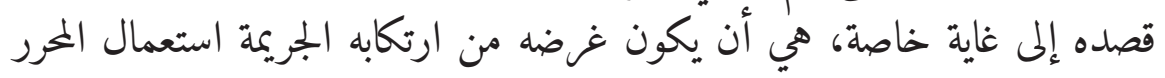

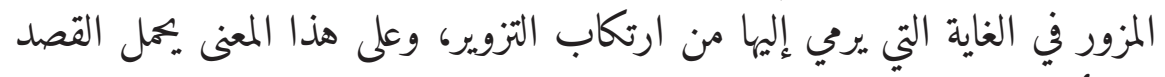

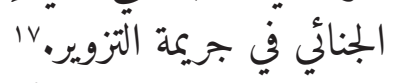

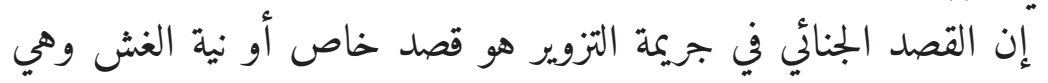

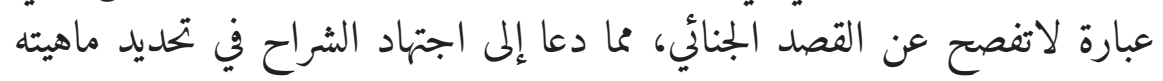

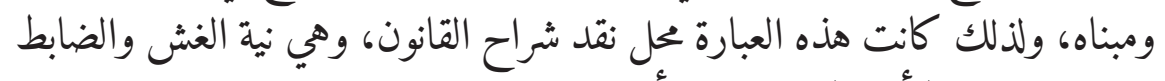

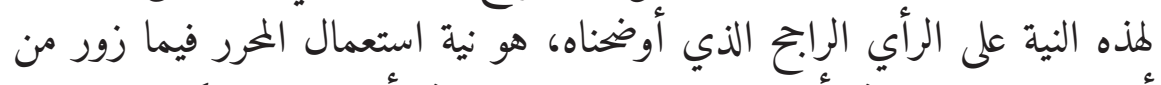

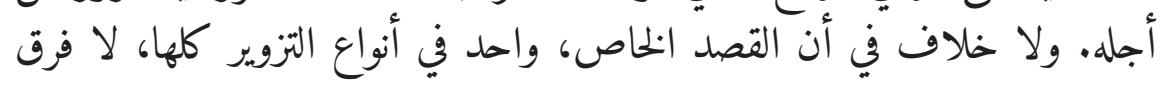

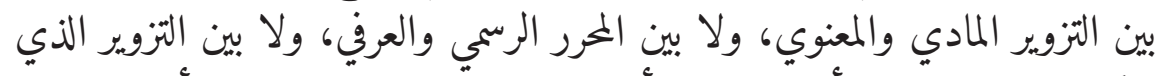

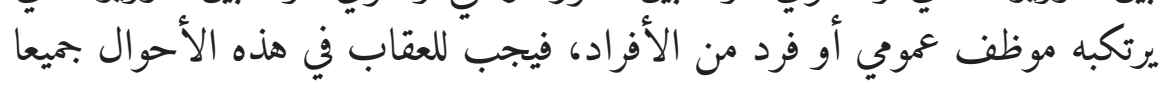

$$
\text { المرجع السابق، ص } 91 .
$$


من أنجلهُ، علم المزور أو إمكان علمه بأن المحرر المزور سيستعمل في الغرض الذي زور

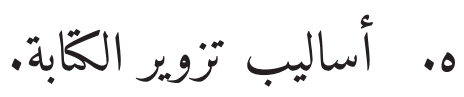

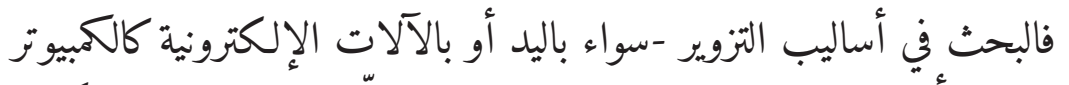

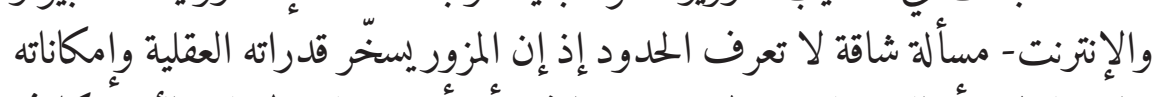

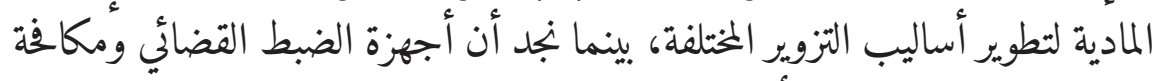

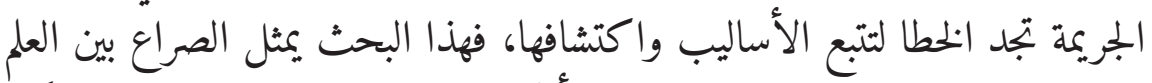

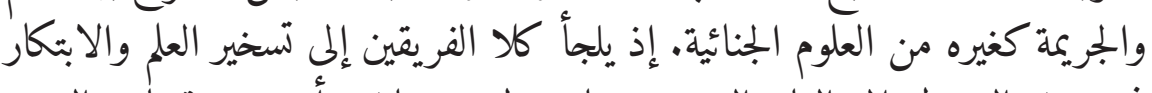

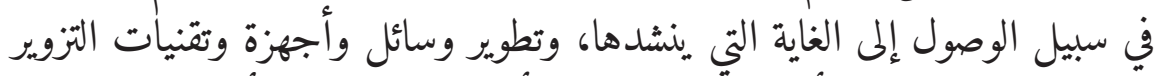

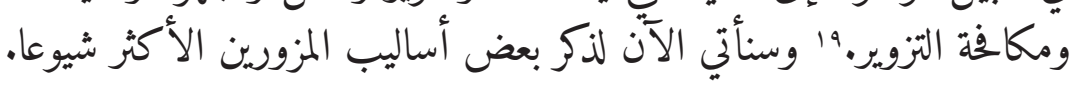

$$
\text { • ا ـ التزوير المادي. }
$$

وهنا يقوم المزور بنقل التوقيع أو إمضاء أو نص معين من سند صحيح إلى إلى سند ينوي اصطناعه، وتتم طريقة النقل هذه بأسلوبلو إلمبين رئيسين:

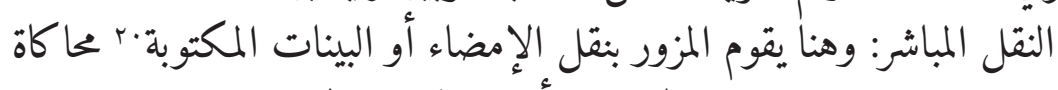

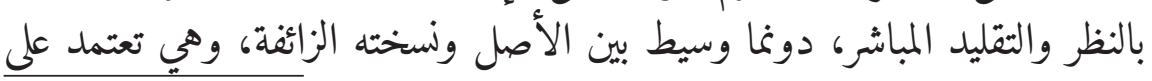

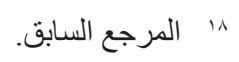

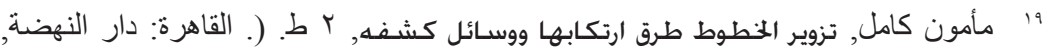

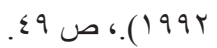
و و من مميز ات الإمضاءات أو الخطوط المنقولة بهذه الطريقة أنها: ( ـ تمناز بعدم الطلاقة أو السلاسة

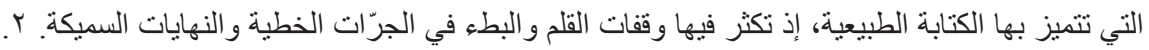

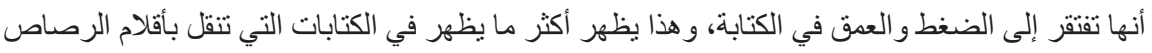

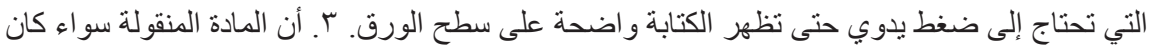

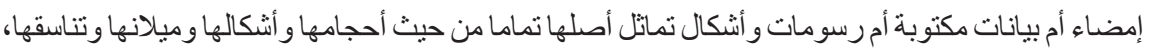
و هذه إحدى مظاهر التزوير ، إذ إن الخط المحرر بكتابة طبيعية لا يمكن أن يتماثل تماما مهما حاول التهات الإنسان

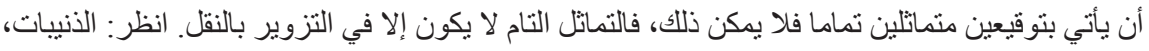

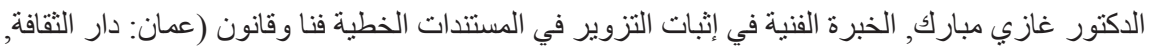

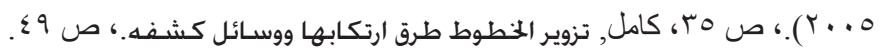


هارة الشخص في الرسم اليدوي وقدرته على تقليد الخطوط اليدوية. كما قد يلجأ

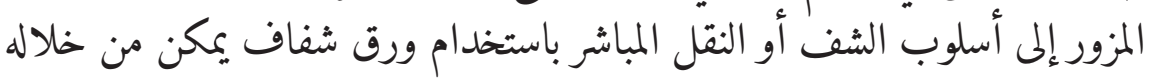

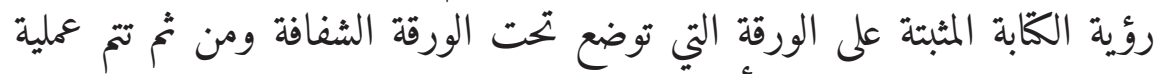

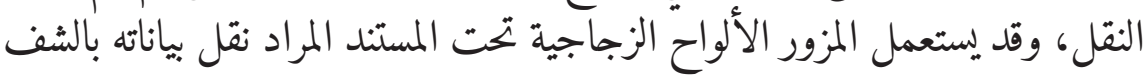

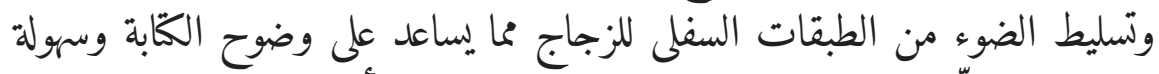

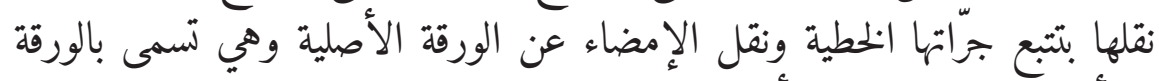

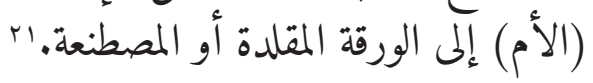

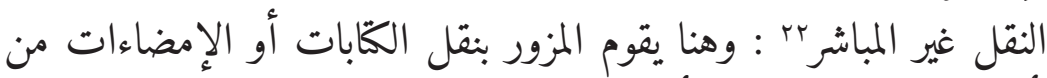

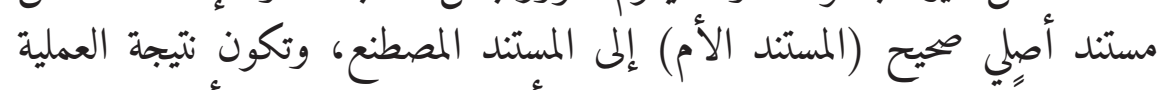

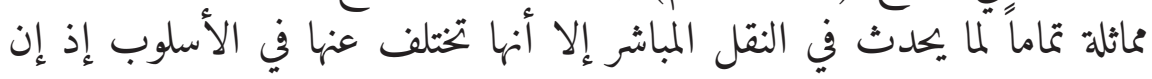

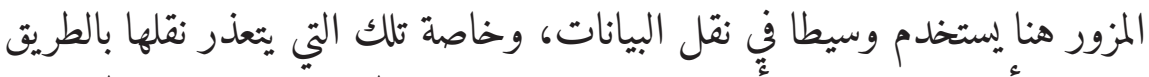

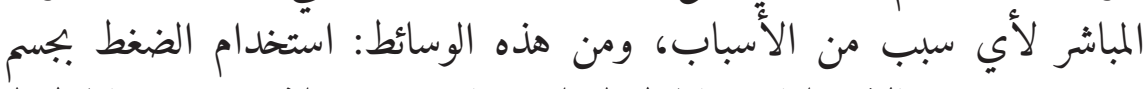

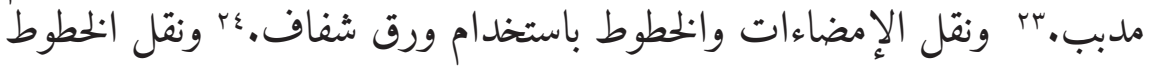

${ }^{21}$ Albert Osborn, Question Documents, 2nd edition (New York: Boyd Printing Company, 1943). Mohd Faisal Mohamed et al., "Islamic Epistemology and Its Relations to Scientific Method in Islamic Law of Evidence”, International Journal of Recent Technology \& Engineering, vol. 8, no. 3 (2019), pp. 4350-2.

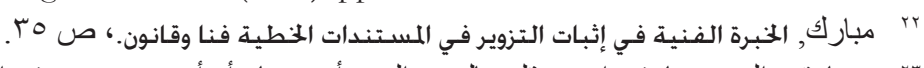

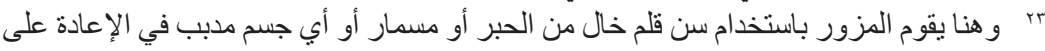

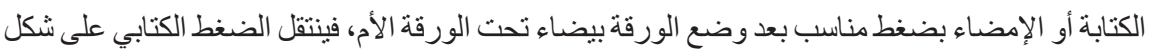

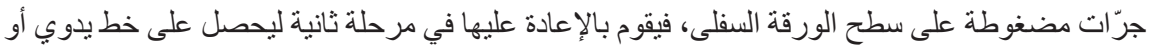

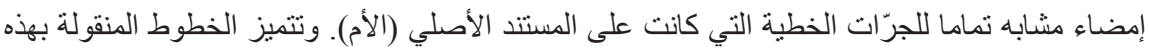

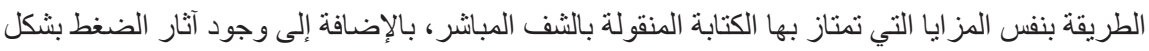

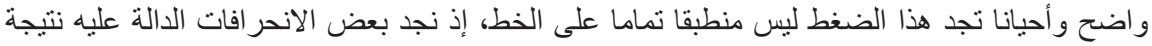
الحركات غير الإر ادية للقلم أثناء الكتابة.

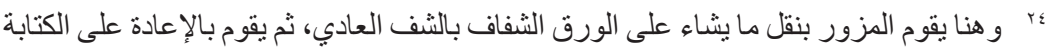

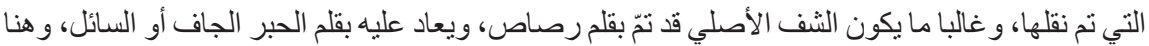
تظهر بقايا الكتابة بقلم الرصاص أثناء الاختبارات المخبرية، كما تظهر أحيانا بقايا المحو الآلي (المدحاة) على سطح الورق. 


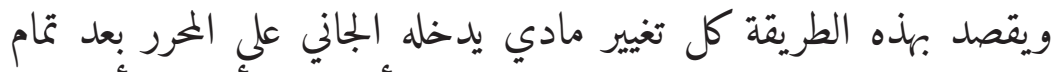

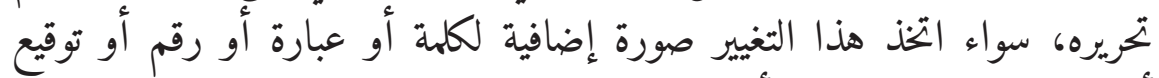

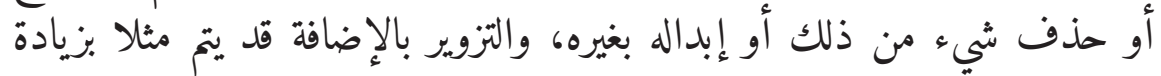

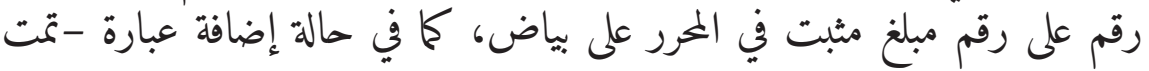

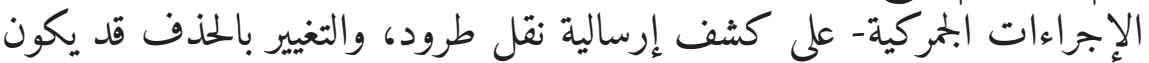

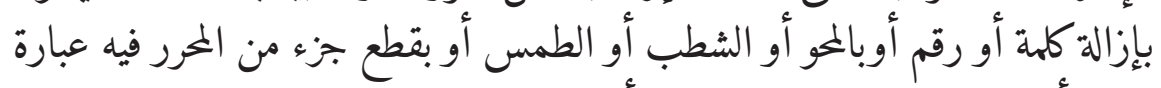

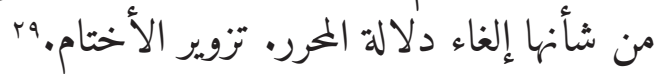

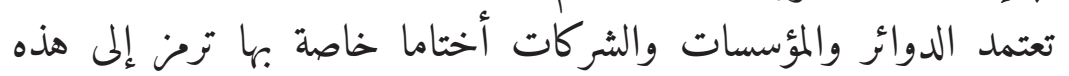

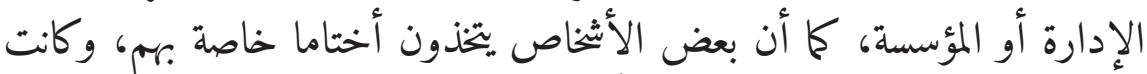

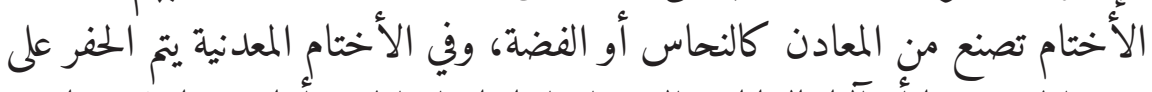

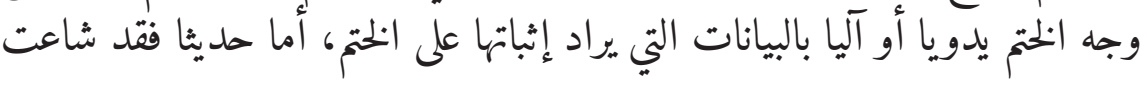

م. إذ يقوم المزور بنقلها عن طريق وضع الورقة الكربّون تحت المستتد الأصلي ومن ثم الإعادة على التوقيع الصحيح لتظهر صورته الكربّونية على الورقة المصطنعة الموضو عة تحت الورقة الكربّونية، و هذه التوقيعات المزورة بهذه الطريقة تمتاز به الخطوط المنقولة بالثف المباشر .

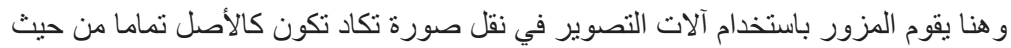
لونها ومواصفاتها ودقتها خصوصا في ظل المبنكرات الحديثة لآلات التصوير الإلكترونية والرقمية، وهذه الطريقة غالبا ما تخدع حتى الخبر اء وتحتاج إلى خبرة ودر اية فنية دقيقة لكثفها. و هنا يقوم المزور بإحداث نقص في بيانات سند موجود وذللك بالإز الة و الحذف في بيانات مختارة منه على نحو يظهر معه وكأنه وجد على هذا النحو أو تمهيدا لإضافة بيانات جديدة بدل الكتابات التي تمت بـات إز التها، و الإز الة هذه تتم بإحدى طريقتين: ( (1) الإزالة الميكانيكية (Mechanical Erasure) و هنا يستخدم

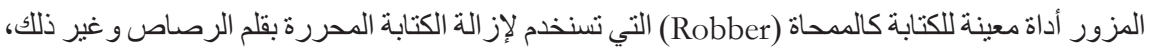
(Y) الإز الة الكيمائية، و هنا يلجأ المزور إلى استخدام مواد التبييض التي تعمل على إز الة الألوان والأحبار إز الة تامة نتيجة التفاعلات الكيمائية مع هذه الأحبار ، و هذه الطريقة غالبا ما تترك آثار ها على شكل بقع تظهر على سطح السند عند فحصه مخبريا. وفي هذه الحالة يعمد المزور إلى إضافة حرف أو رقم أو جرة خطية أو فقرة أو إمضاء إلى السند الأصلي تحدث تغيير ا في معناه، و غالبا ما يتم كثف هذه الإضافة من خلال فحص مكونات السند استتادا إلى في وجود الاختلاف في ظروف كتابة السند الأصلي وما أضيف إليه من حيث... انظر : حجازي، د. عبد الإند الفتاح

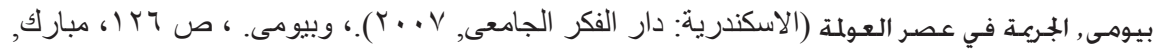

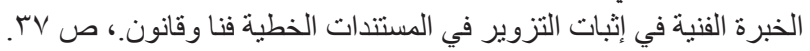

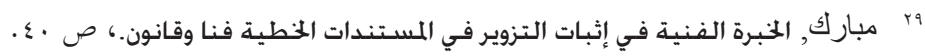


الأختام البلاستيكية المعروفة. وتمتيز انطباعات الأختام (Stamp Impression)

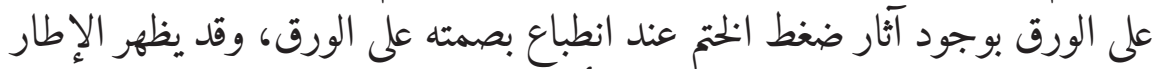

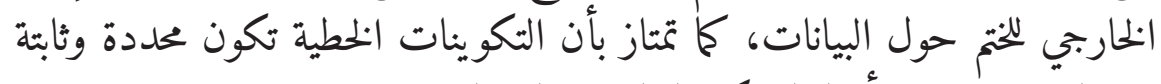

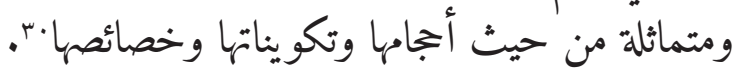

$$
\text { التزوير المعنوي. }
$$

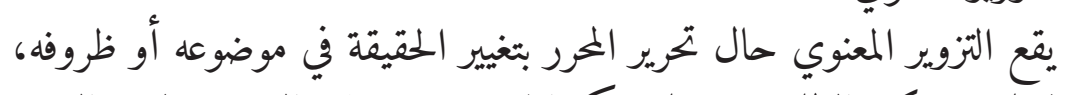

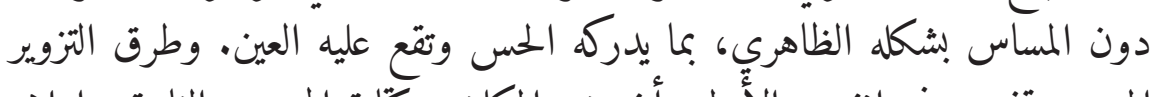

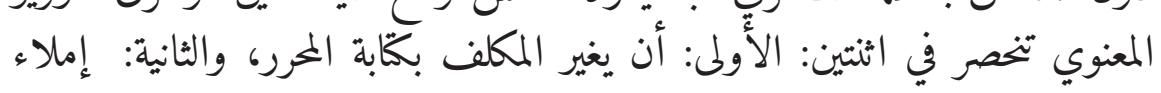

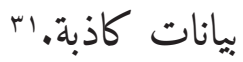
- أن يغير المكلف بكتابة المحرر.

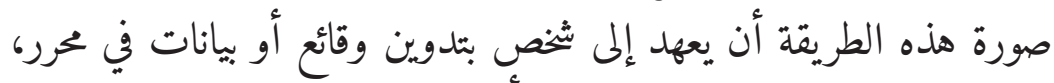

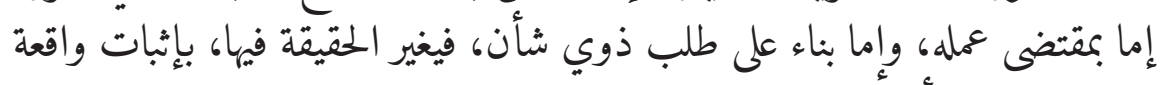

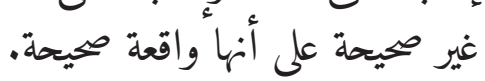
وقد يقع التزوير بهذه الطريقة في المحرر الرسمي، وفي هذه الحاله لأله لا يتصور

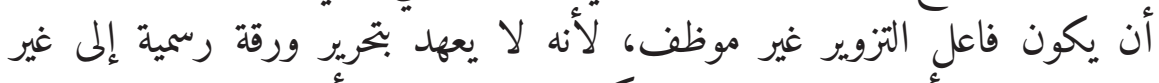

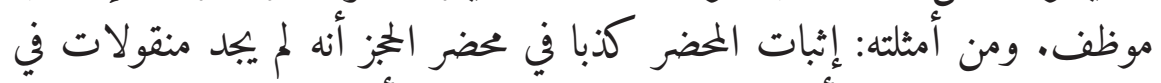

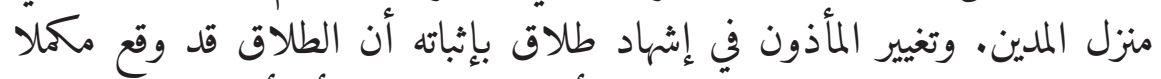

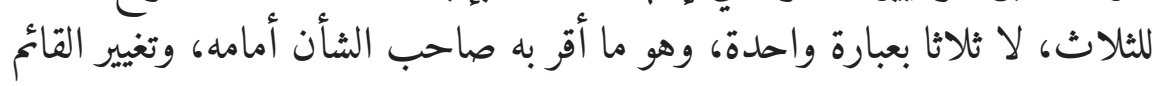

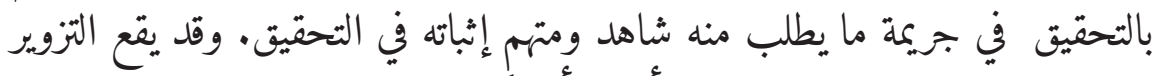

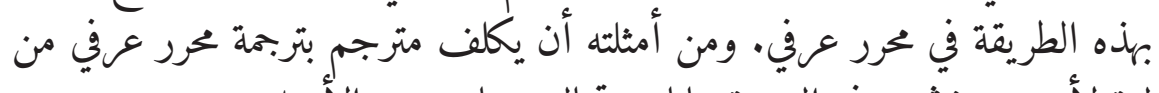

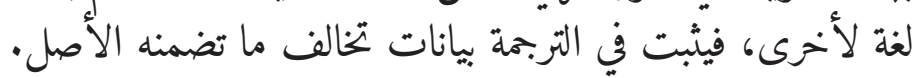

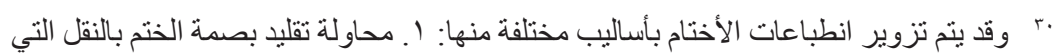

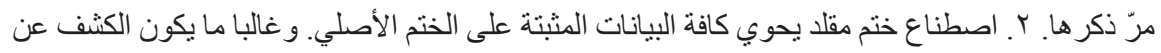

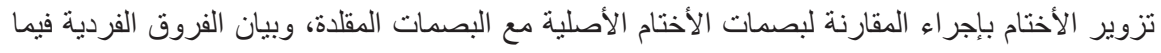

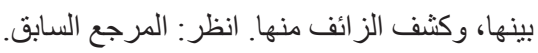

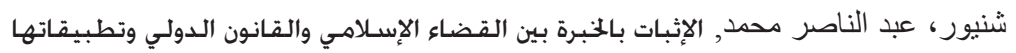

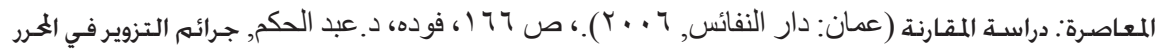

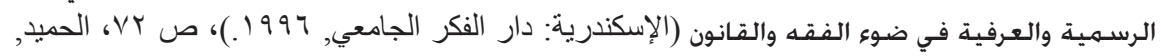

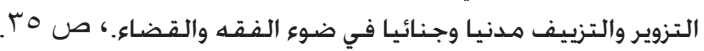




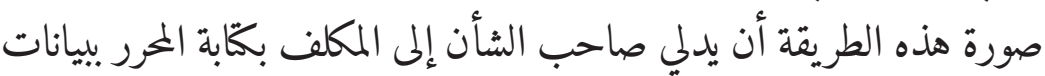

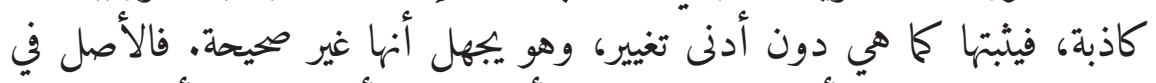

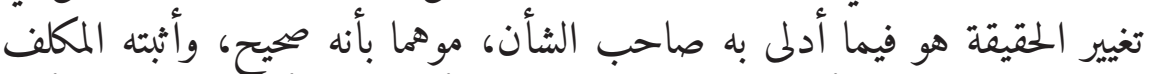

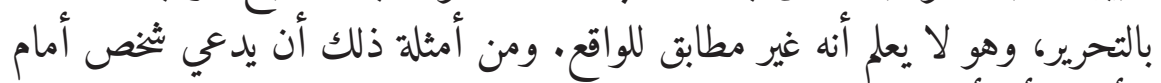

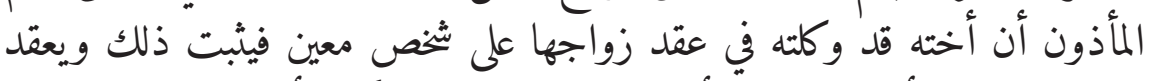

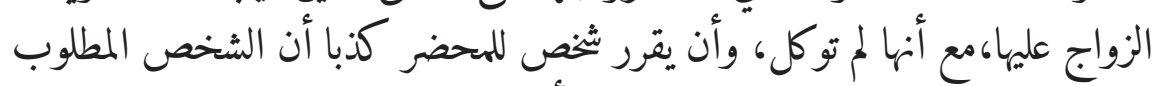

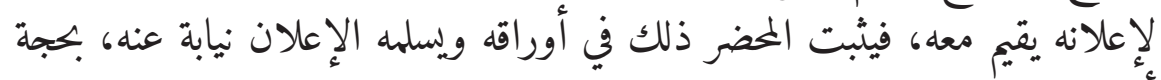

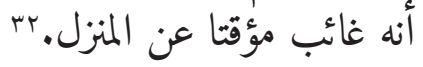

\section{و. عقوبة تزوير الكتابة في الفقه والقانون الماليزي.}

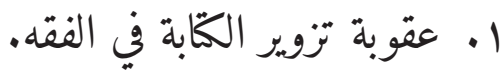

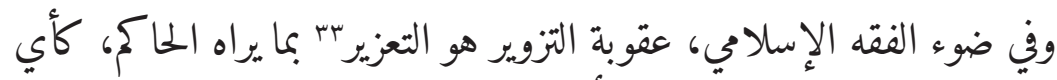

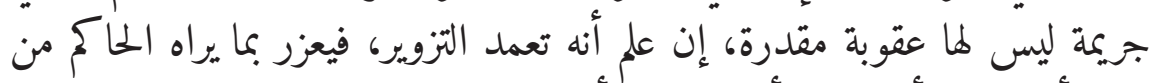

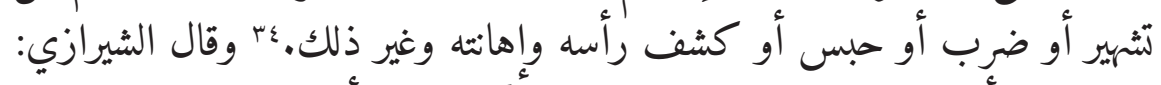

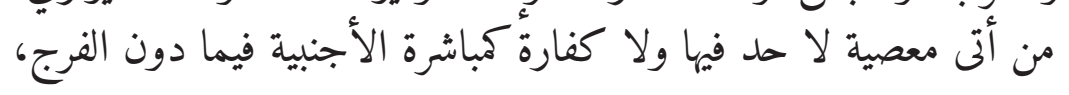

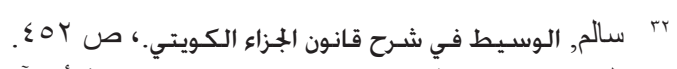

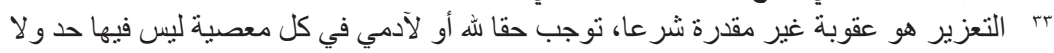

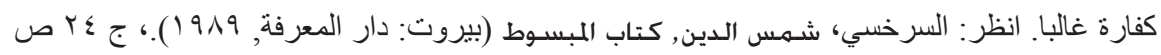

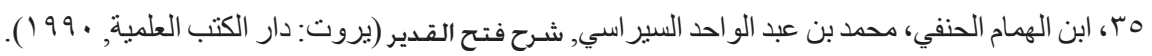

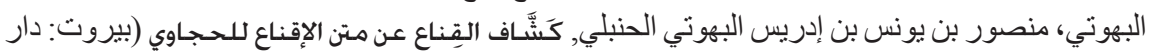

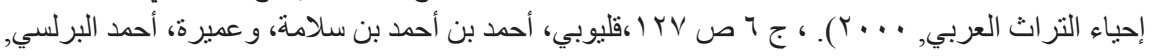

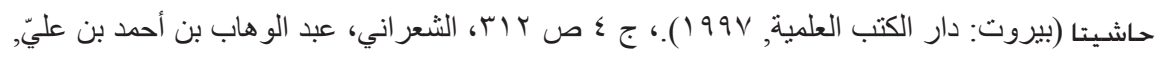

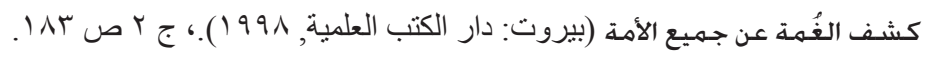

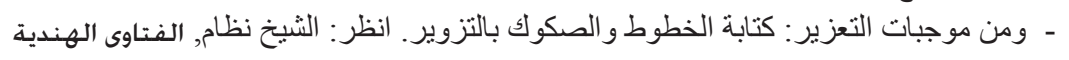

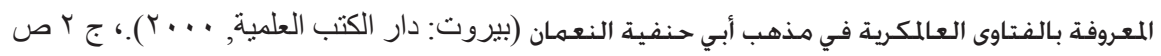
INV

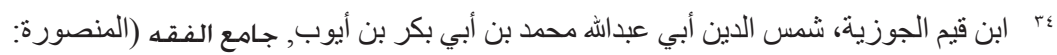

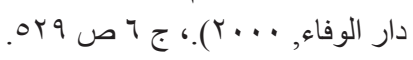


وسرقة ما دون النصاب، أو السرقة من غير حرز، أو القذف بغير الزنا، أو الجناية

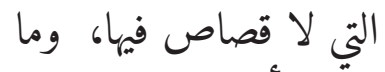

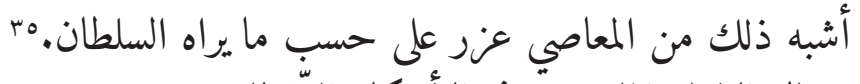
وقال الإمام الماوردي" في الأحكام السّلطانية:

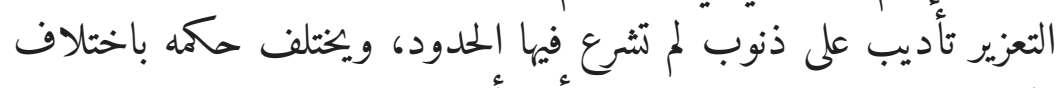

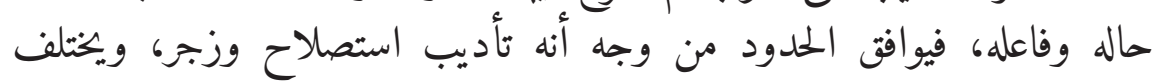
بحسب اختلاف الذنب. بـاهن • عقوبة تزوير الكّابة في القانون الماليزي.

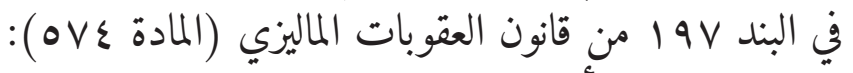

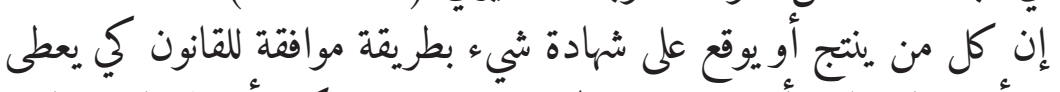

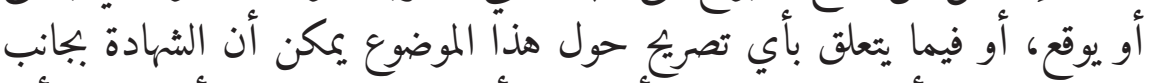

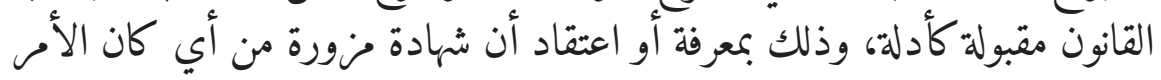
المهم، يلزم معاقبة كما لتقديمه بينة كلاذبة.

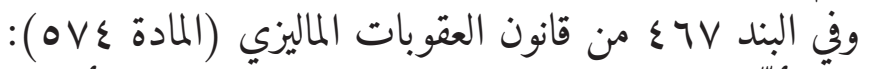

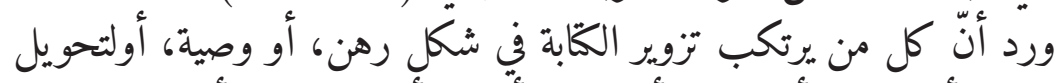

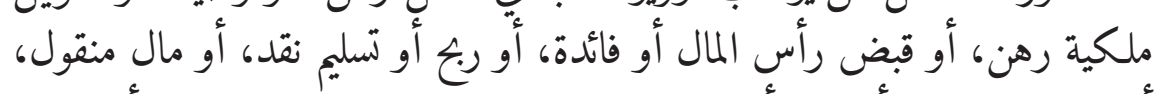

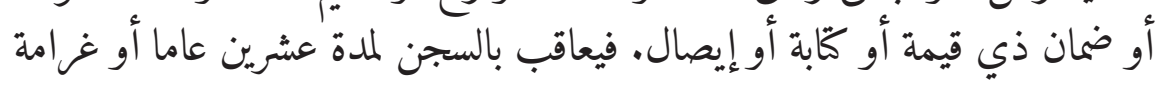
معينة.

$$
\text { وفي البند ه7 مـ من قانون العقوبات الماليزي (المادة عVه): }
$$

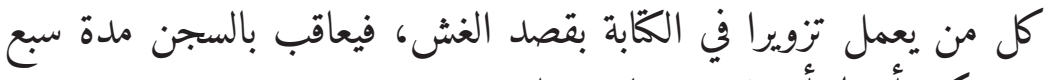
سنوات، ويمكن أيضا أن تفرض عليه غرامة.

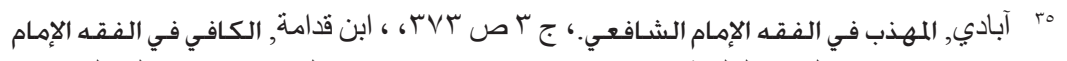

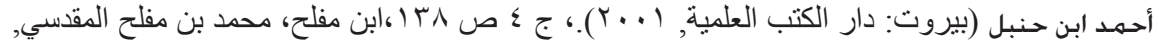

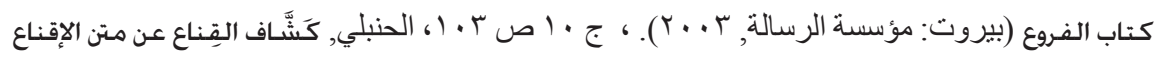

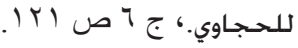
بَ الماوردي، أبو الحسن علي بن محمد بن حبيب, الحاوي الكبير في الفقه مذهب الإمام الشـافعي

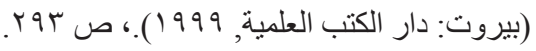




\section{ز. إجراءات تحقيق صحة الكتابة في الفقه الإسلامي والقانون} الماليزي

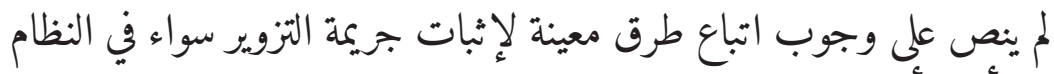

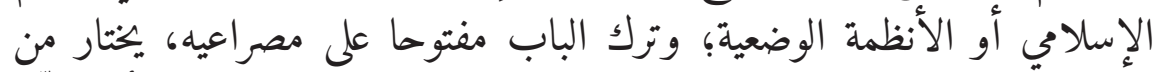

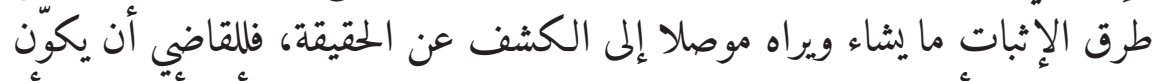

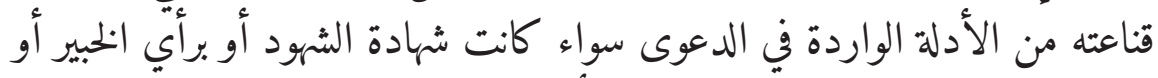

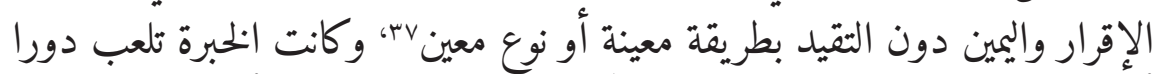

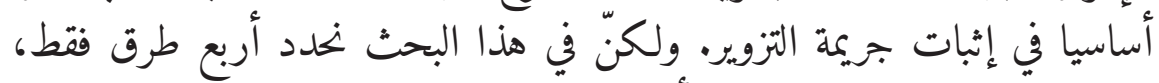
وهي: الإقرار والشهادة واليمين ورأي الخبير.

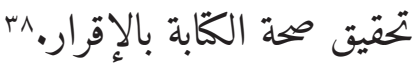

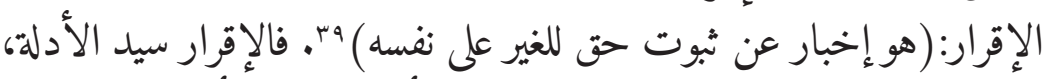

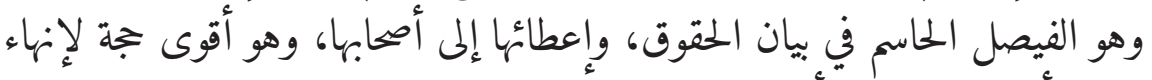

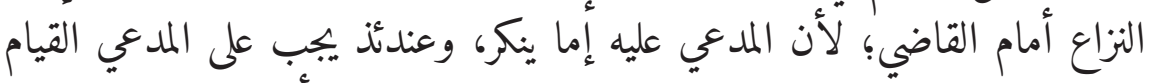

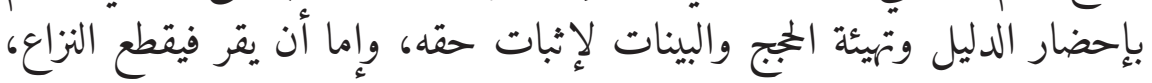

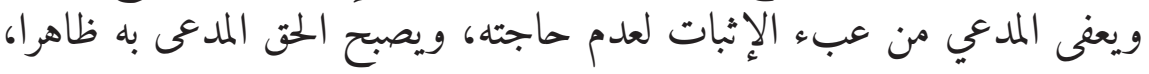

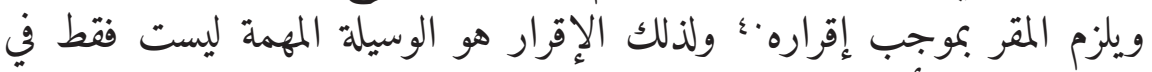

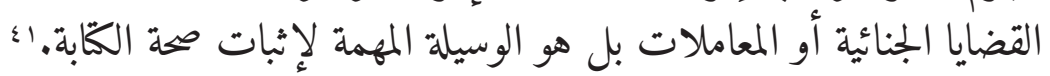

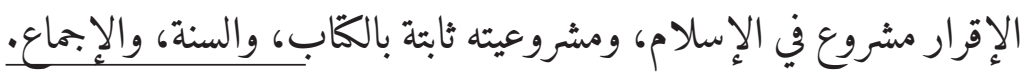

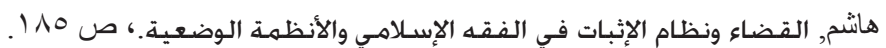

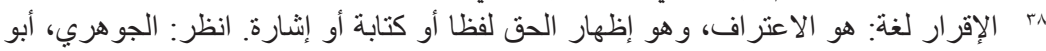

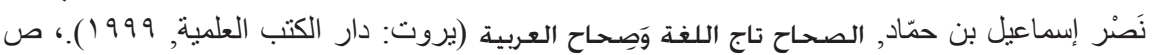

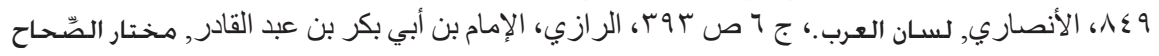

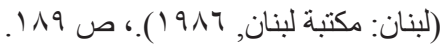

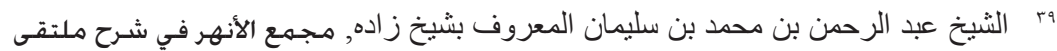

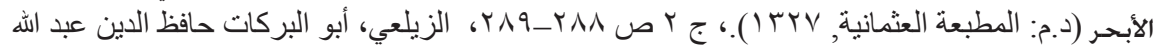

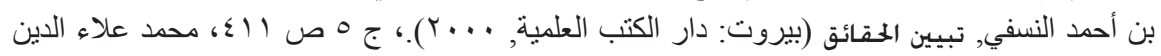

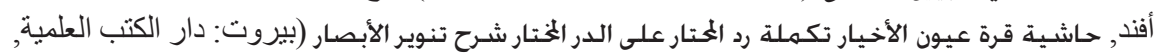

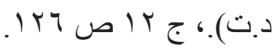

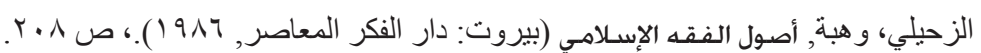

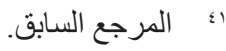


فالآيات الواردة في مشروعية الإقرار تخسب على الإقرار بشكل عام، وما يصلح

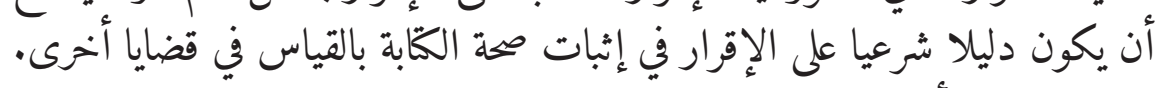

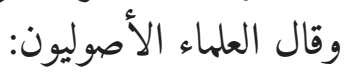

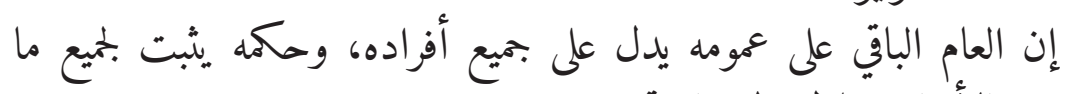

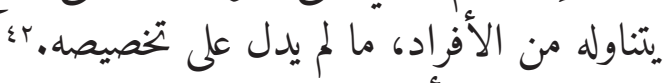

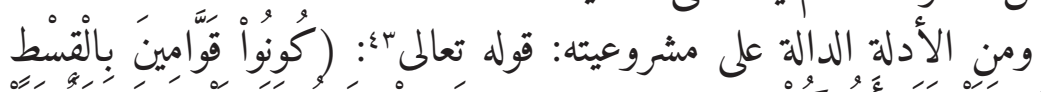

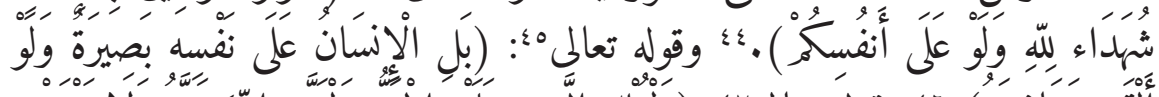

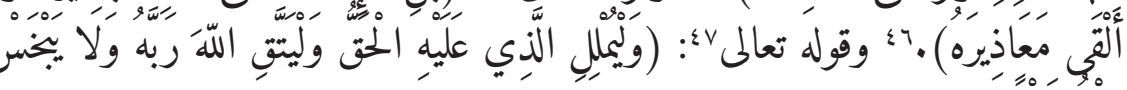

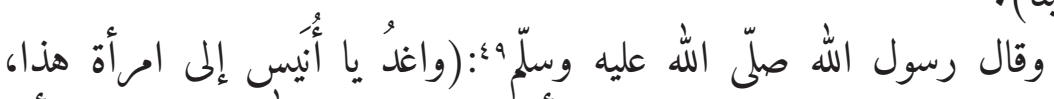

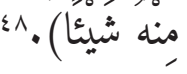

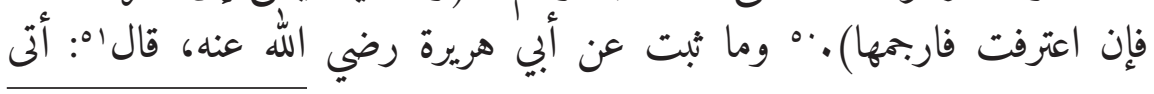

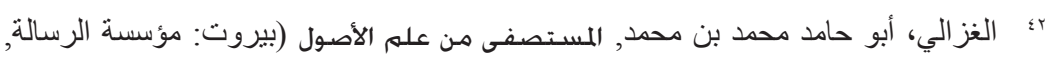

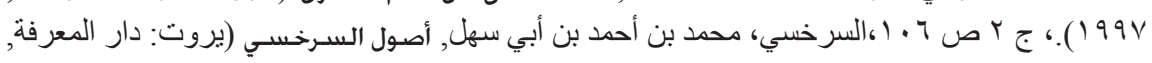

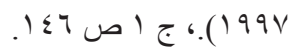

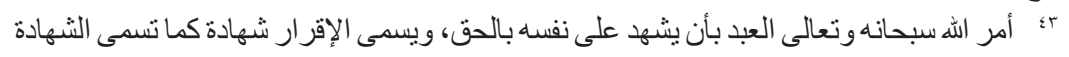

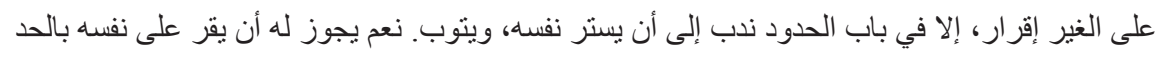

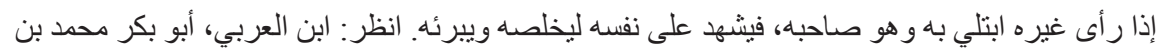

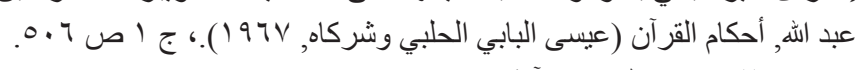

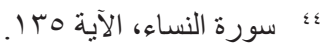

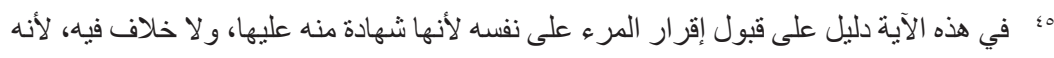

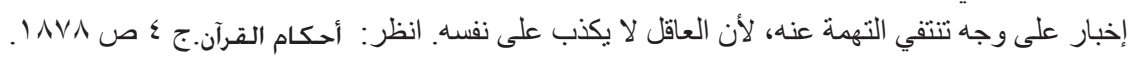

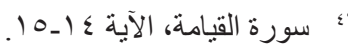

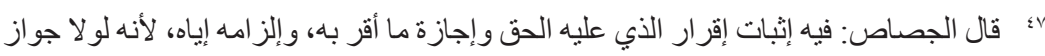

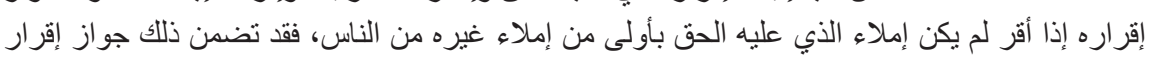

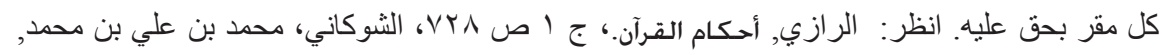

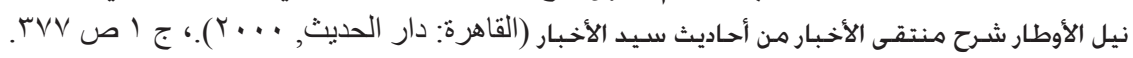

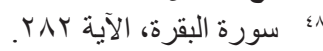

9؛ فعلق الحكم برجم المر أة على اعتر افها، فدل على أن الاعتر اف حجة على صاحبه، ودليل تبنى

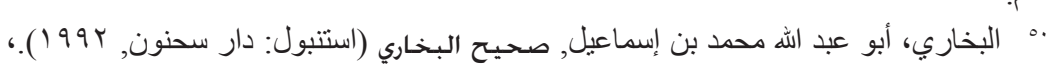
عليه الأحكام.

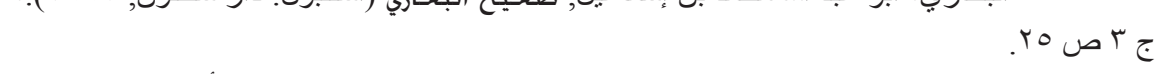

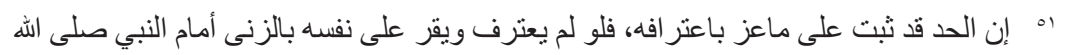

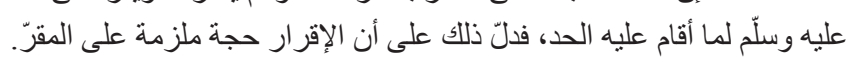




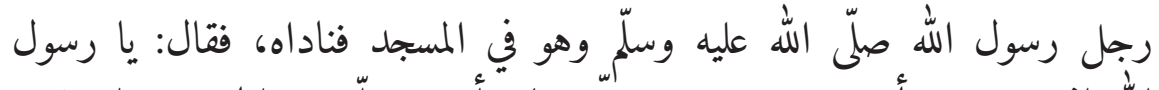

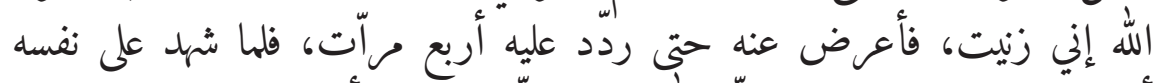

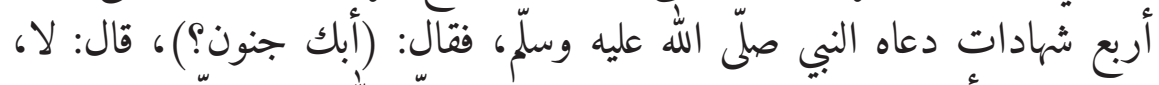

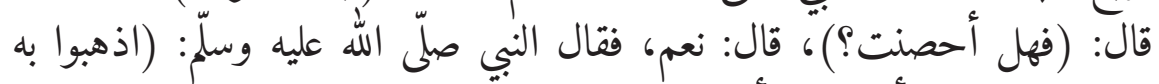

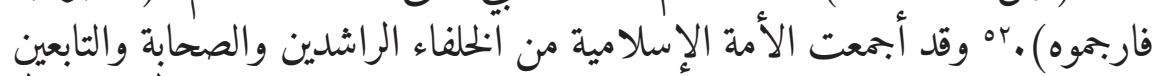

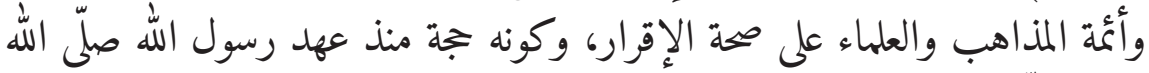

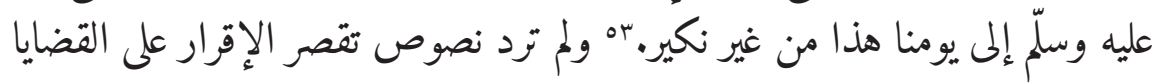

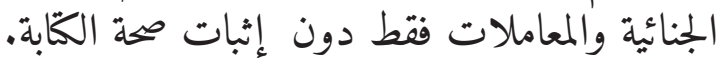

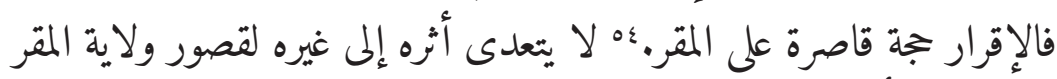

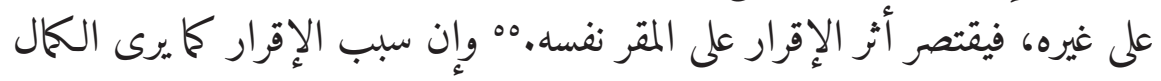

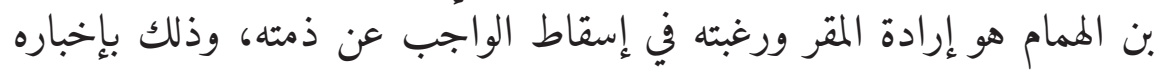

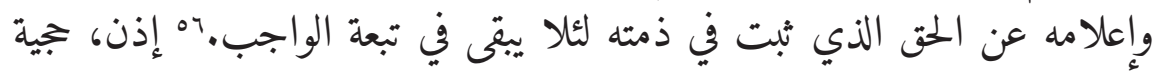

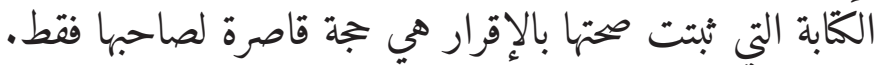

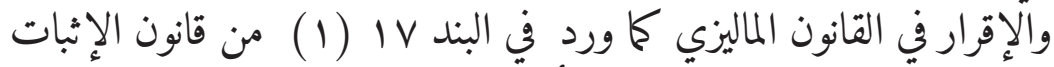

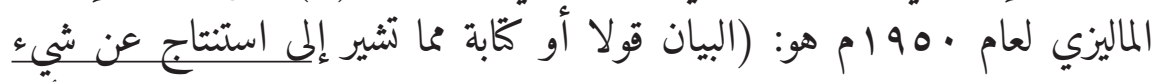

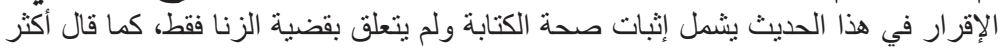

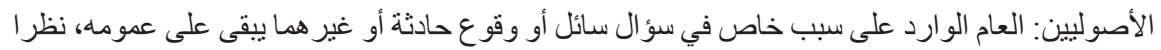

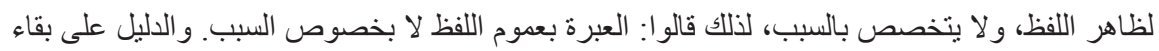

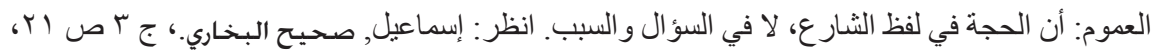

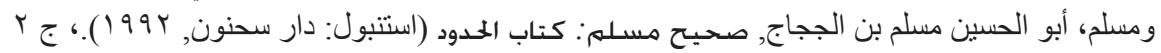

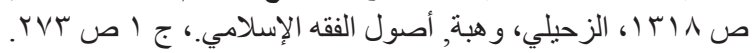

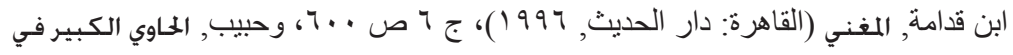

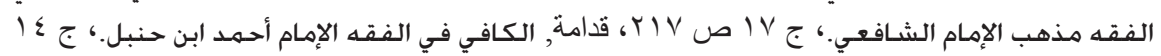

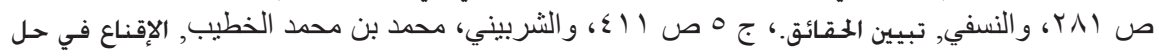

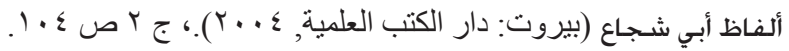

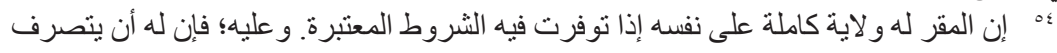

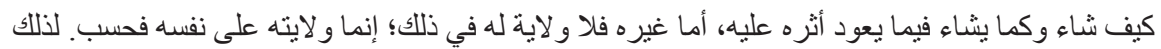

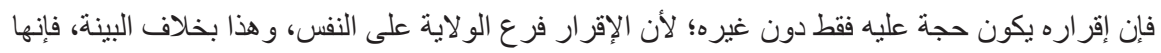
تعتبر حجة إلى الغير بو اسطة القاضي.

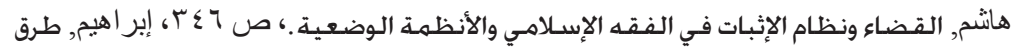

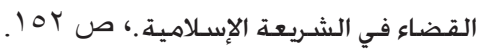

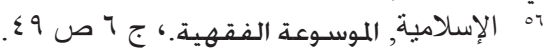




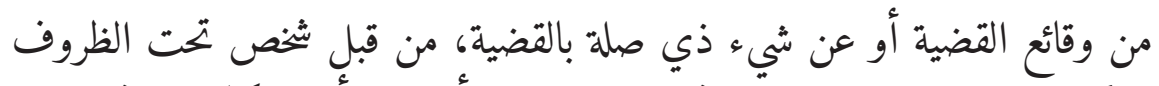

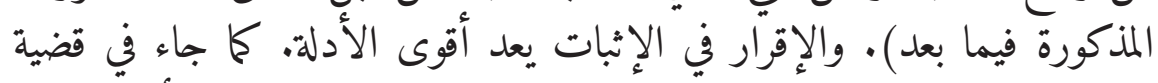

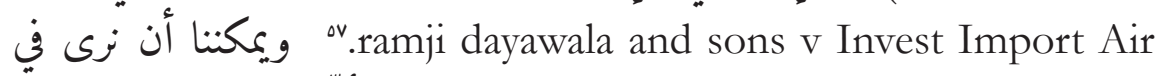

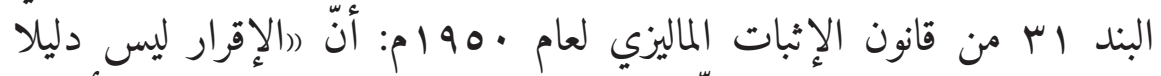

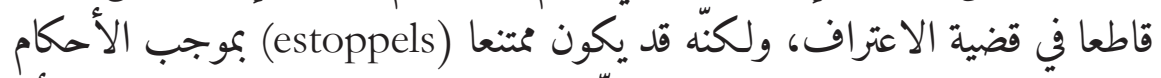

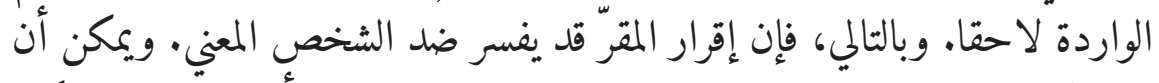

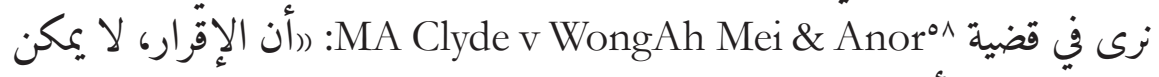
اعتباره نهائيا، أو قاطعا، بل كان مان مفتوحا للتفسير والشرح. تحقيق صحة الكتابة بالشهادة

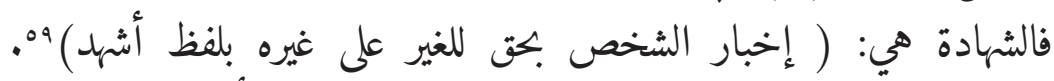

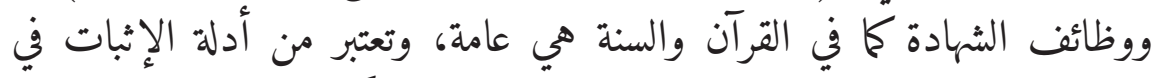

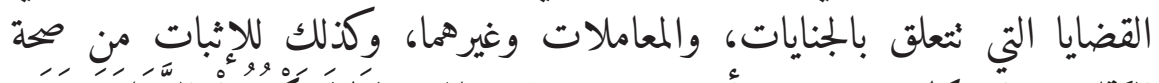

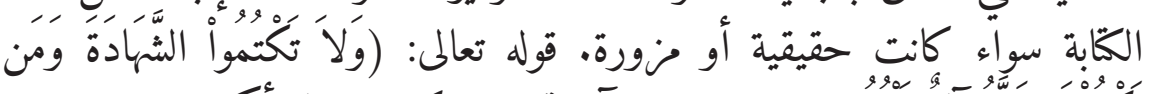

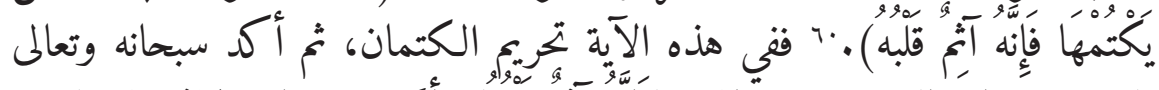

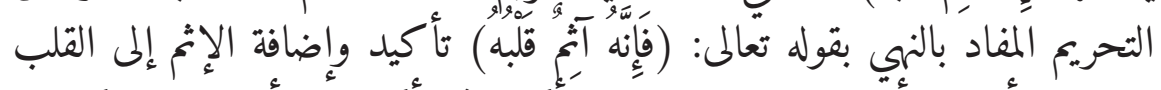

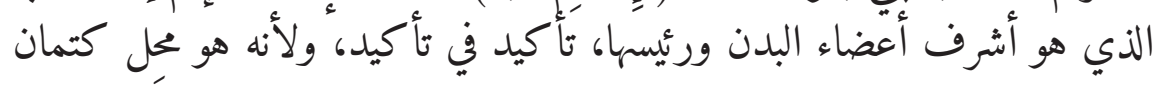

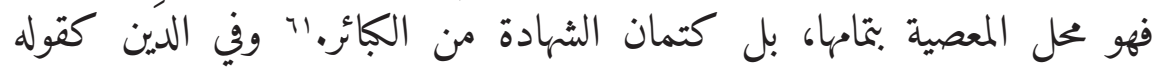

57 Augustine Paul. S, Evidence: Practice and Procedure (Selangor: LexisNexis, 2010), p. 209.

58 Ibid, p. 373.

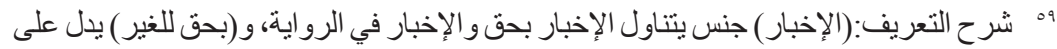

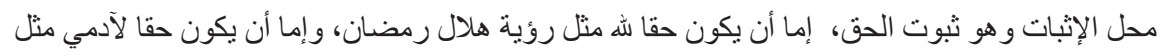

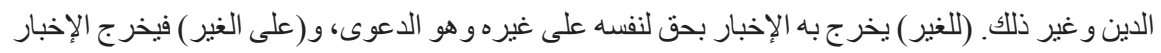

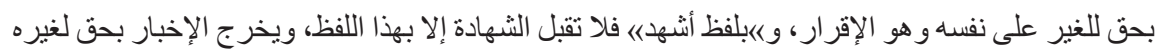

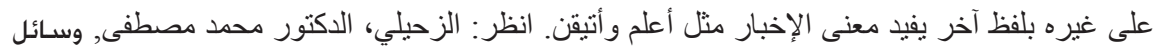

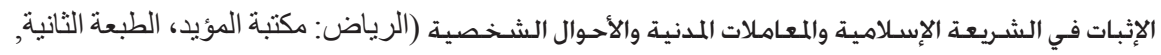

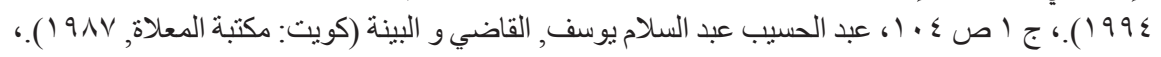

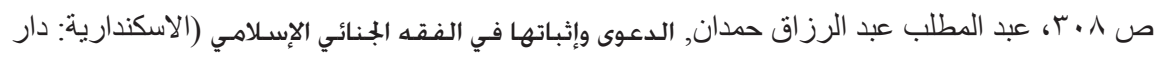

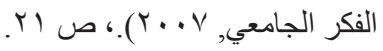

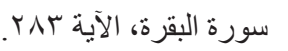
" القرطبي، أبو عبد الله محمد بن أحمد الأنصاري, الجامع لأحكام القرآن (بيروت: دار إحياء التراث 


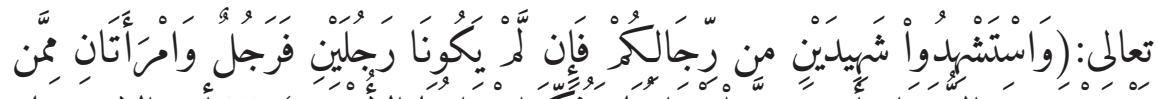

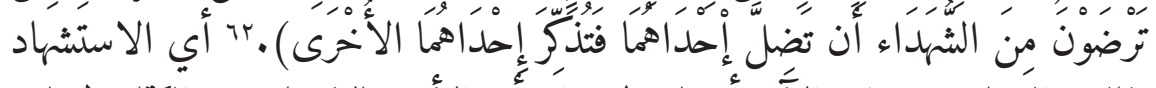

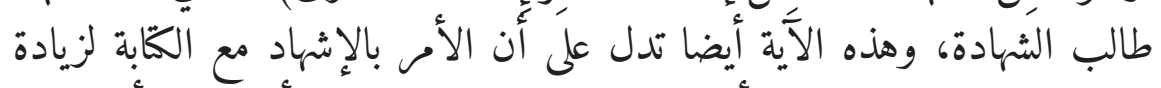

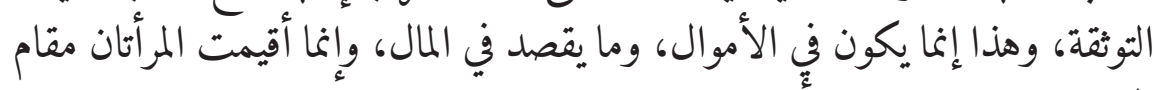

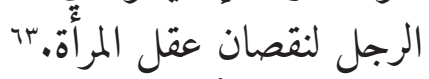

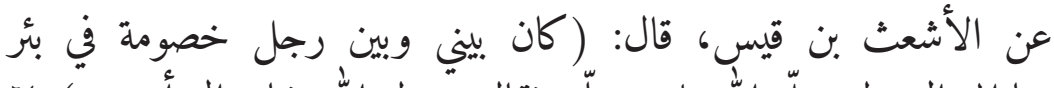

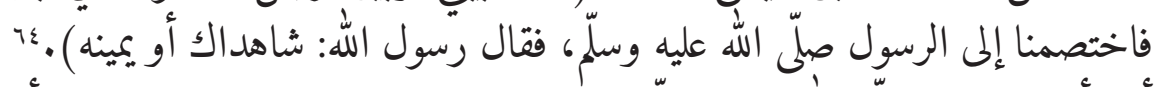

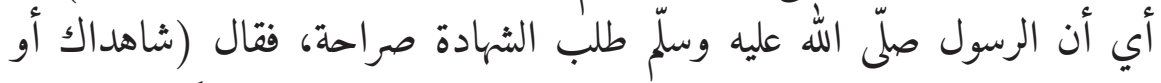

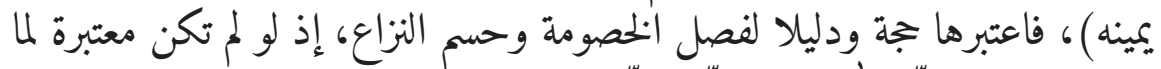

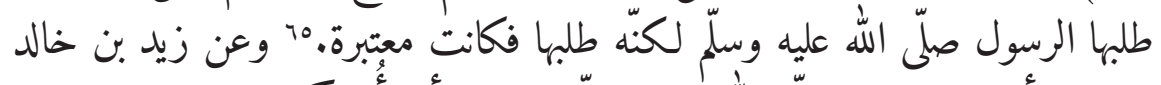

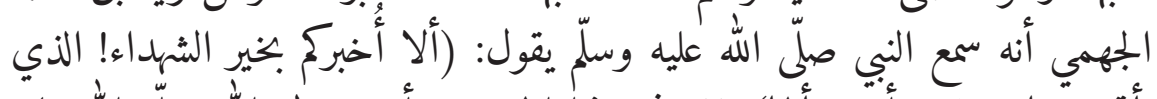

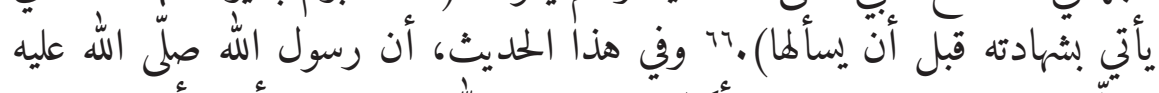

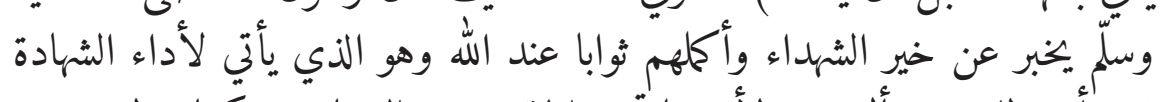

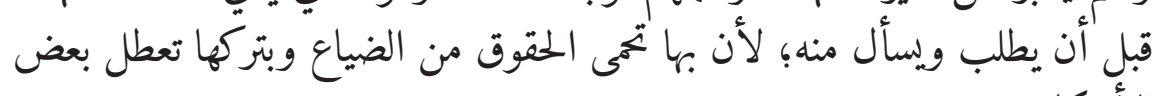
الأحكام. في أن بطلب

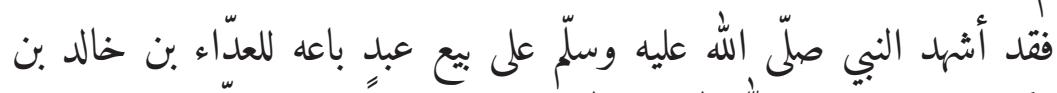

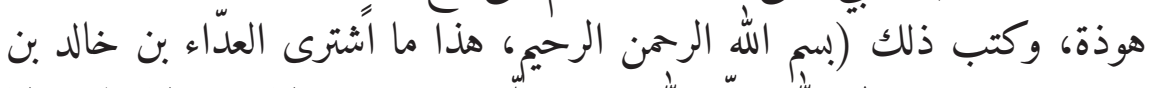

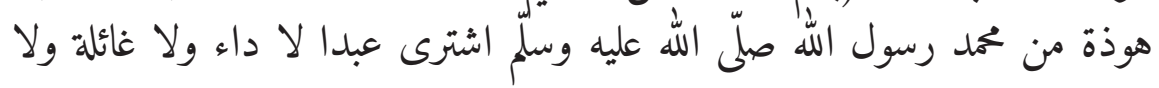

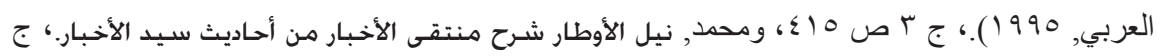

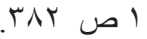

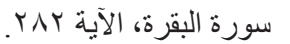

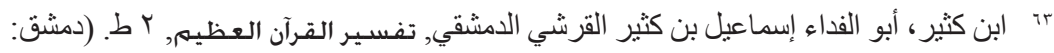

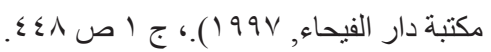

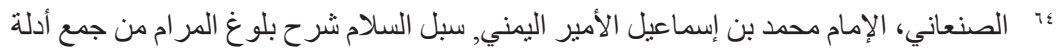

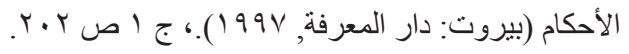

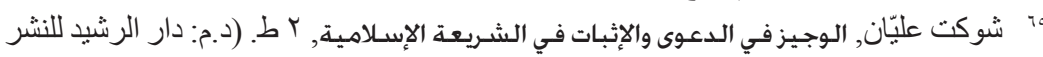

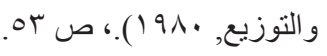

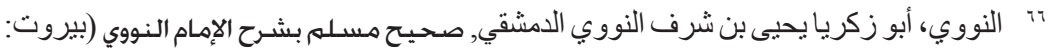

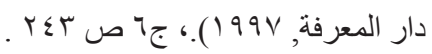

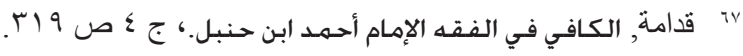




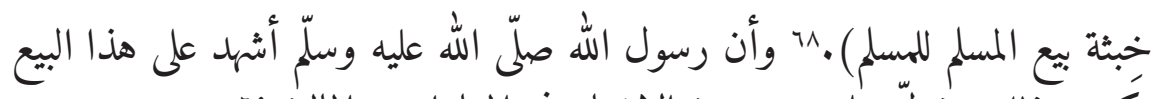
وكتب ذلك، فدلّ على مشروعية الإشهاد في المعاملات المات المالية. 19

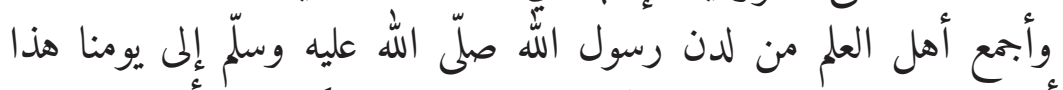

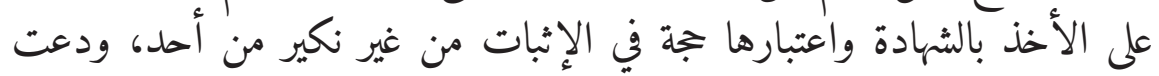

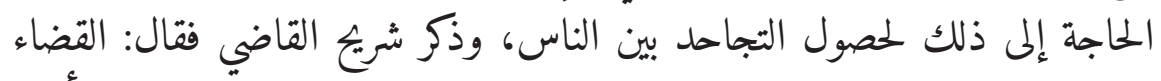

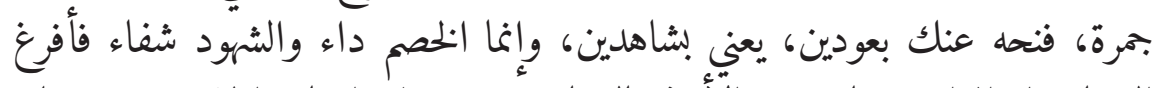

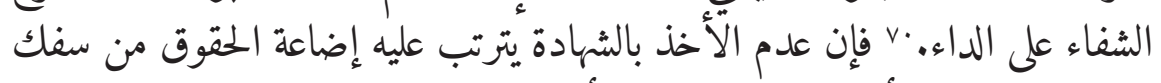

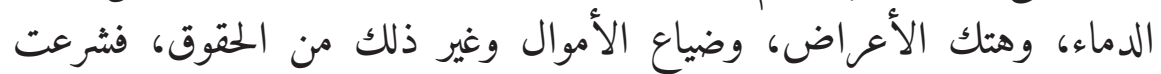

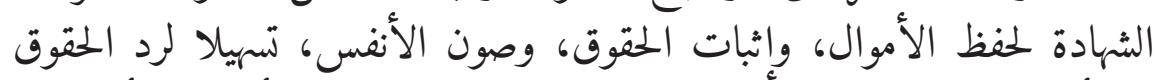

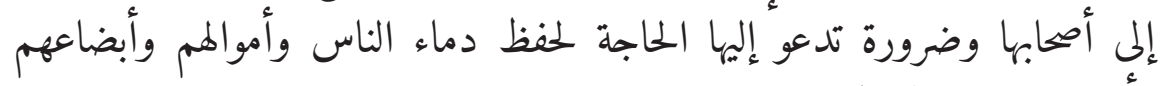
وأعراضهم عن الضياع. وتناول قانون الإثبات كيف تكون الفيان الحقائق المقترحة في المحكمة بواسطة

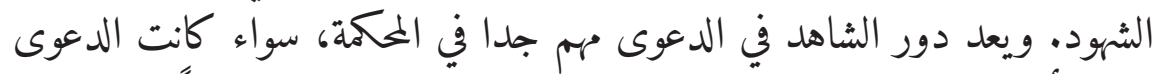

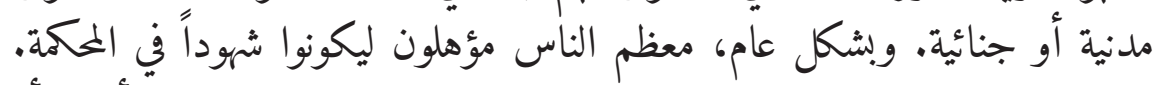

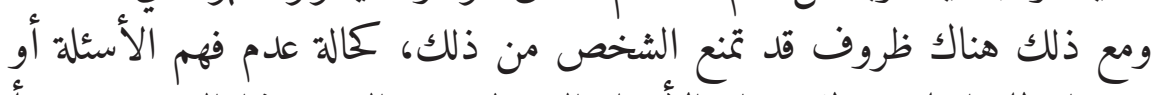

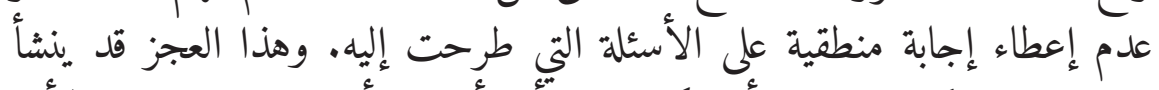

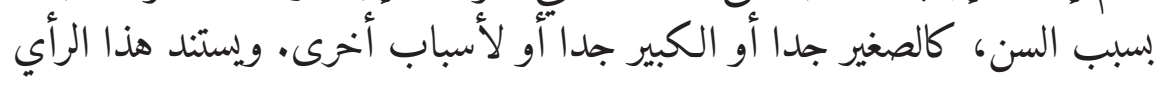

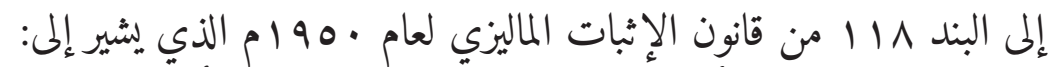

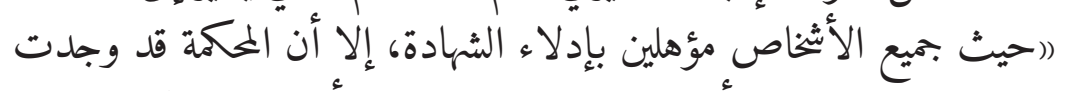

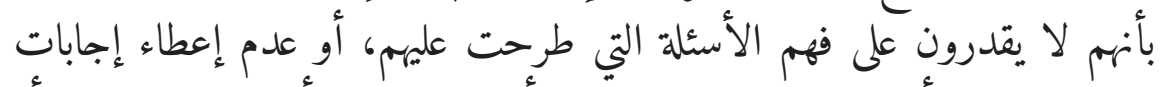

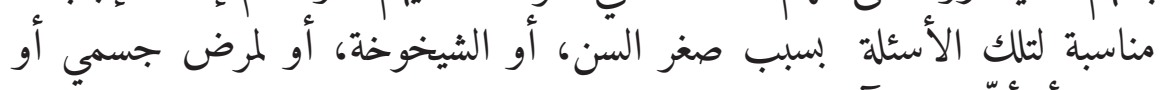

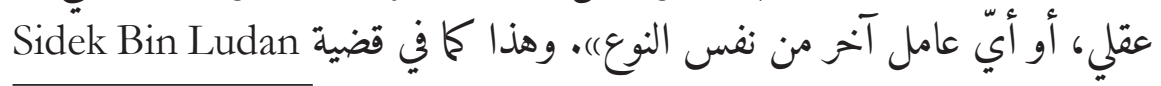

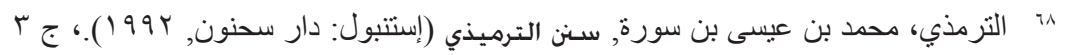

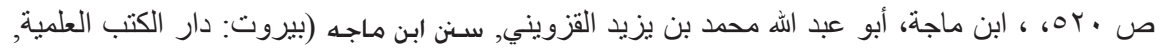

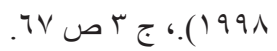

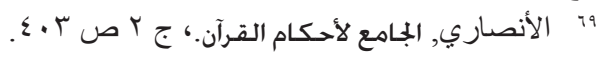

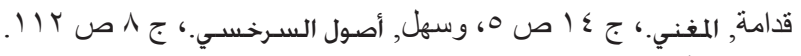

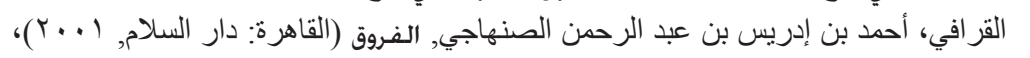


V Public Prosecutor ${ }^{\mathrm{Yr}}$

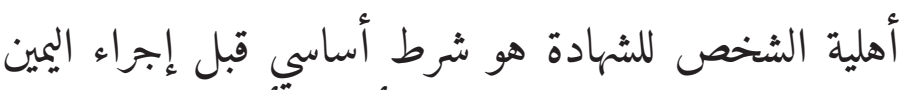

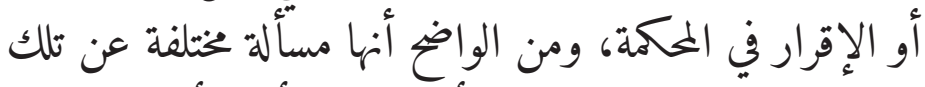

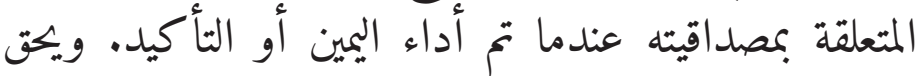

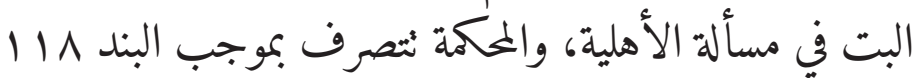

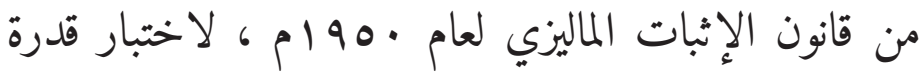

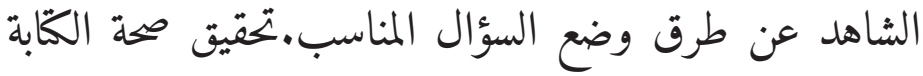
باليمين.

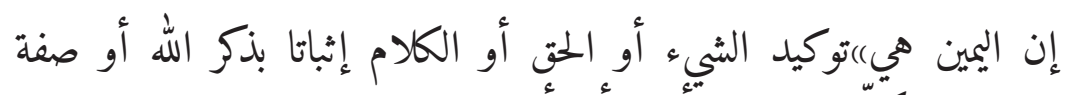

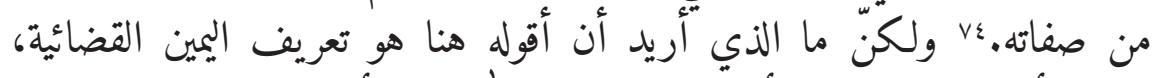

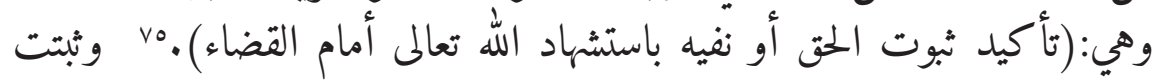

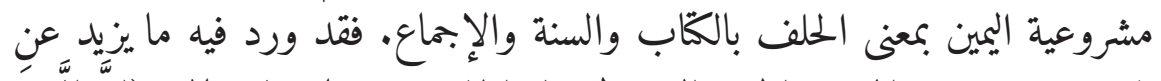

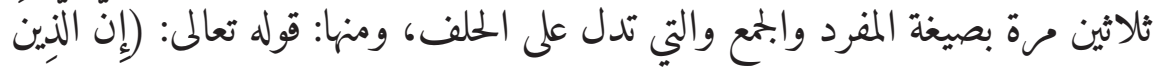

72 See Sidek Bin Ludan v Public Prosecutor (1995) 3 MLJ 178; Jal Zabdi Mohd. Yusoff, Pengenalan Undang-Undang Keterangan di Malaysia (Kuala Lumpur: Universiti Malaya, 2008), p. 245; Ahmad Syukran Baharuddin, "The Integration of Forensic Science Fundamentals and Al-Qarinah Towards Achieving Maqasid Al-Shari'ah", PhD. Dissertation (Johor: Universiti Teknologi Malaysia, 2017); Ahmad Syukran Baharuddin et al., "Catalysing Global Peace through the Strengthening of Forensic Science Application in Shariah Law", Al-Shajarab: Journal of the International Institute of Islamic Thought and Civilization, no. Special Issue: Shari'ah and Law as Catalysts for Global Peace (2019), pp. 77-103.

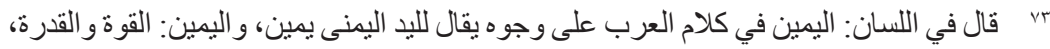

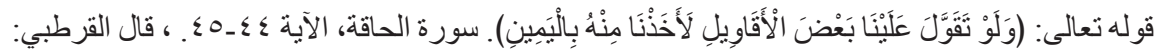

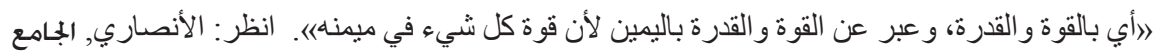

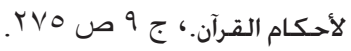

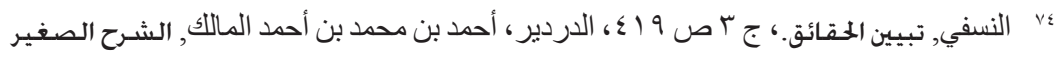

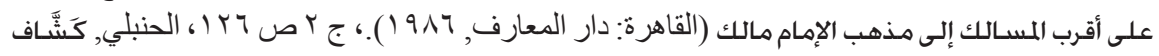

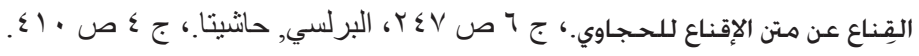

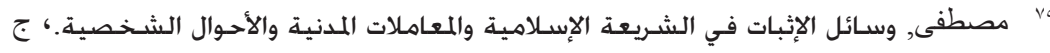




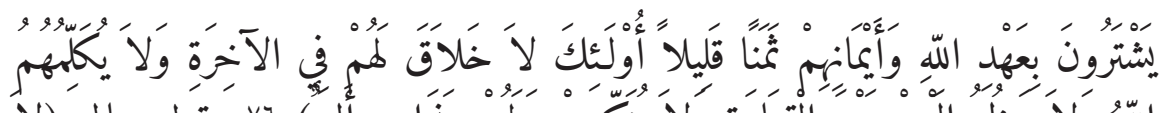

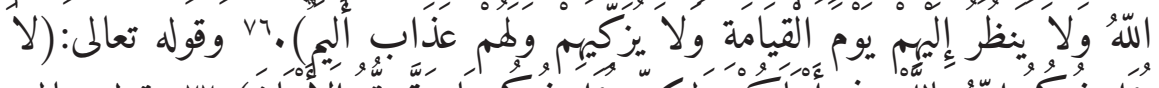

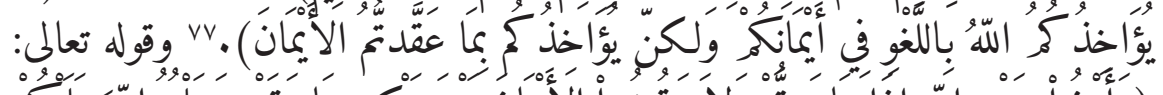

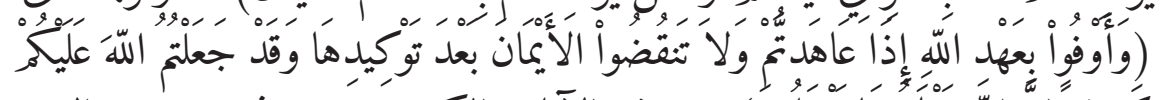

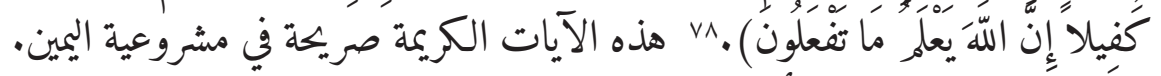

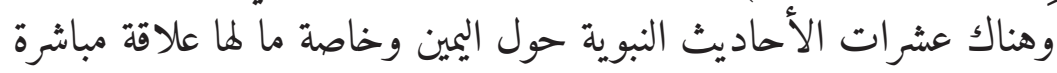

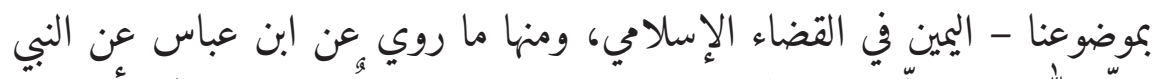

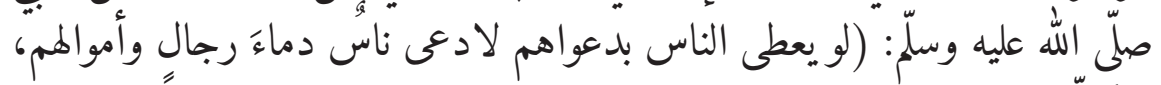

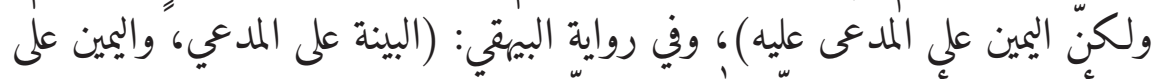

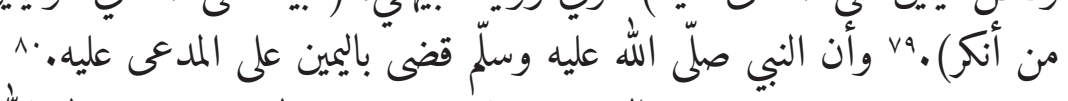

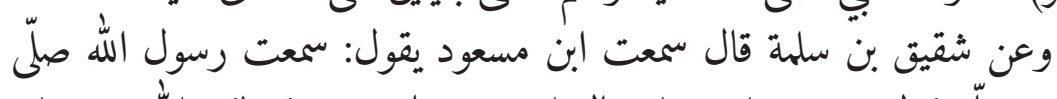

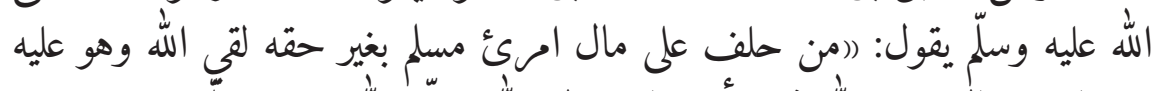

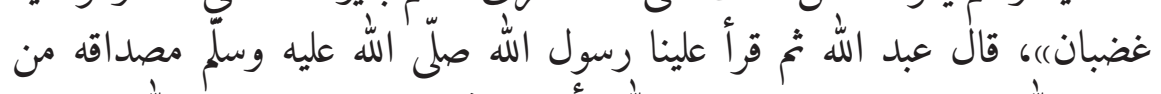

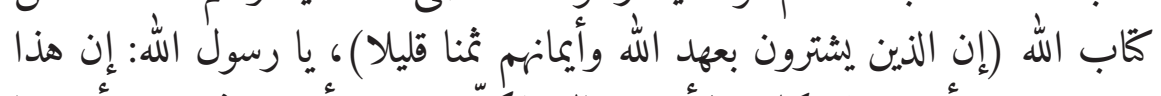

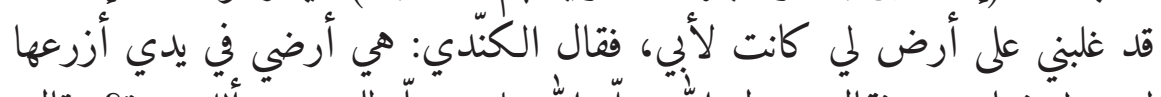

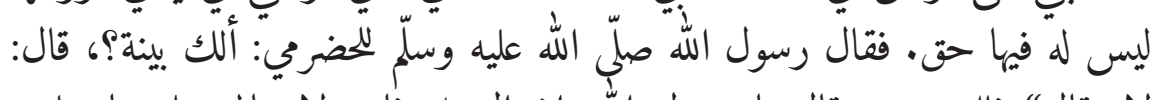

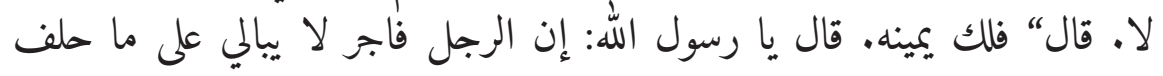

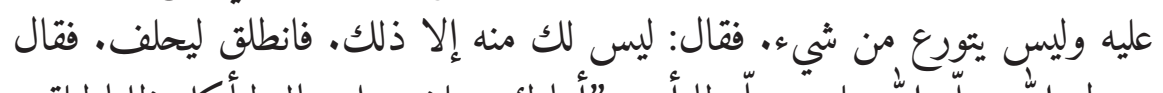

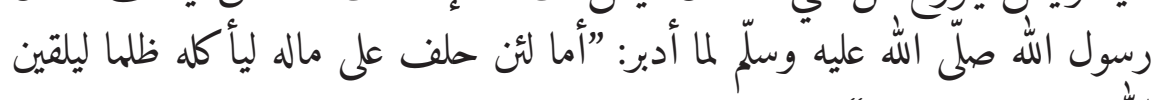

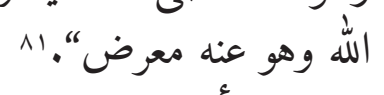
فالأحاديث الشريفة صريحة على مشروعية اليمين على المدعى عليه لدفع

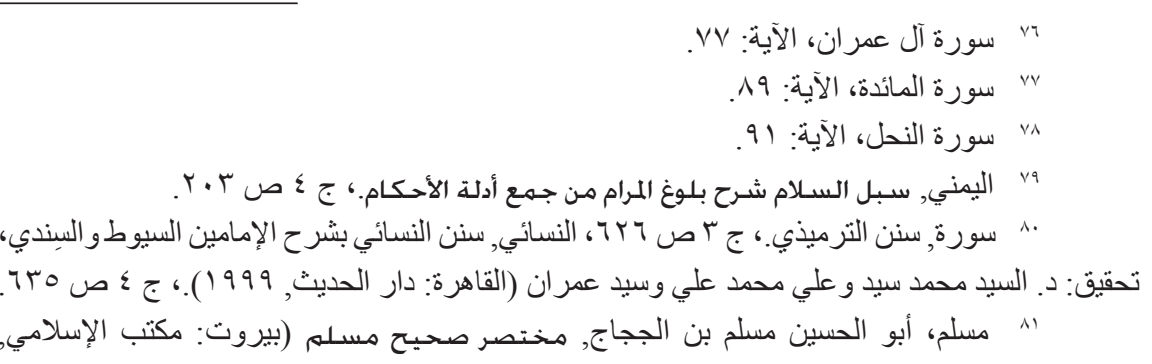




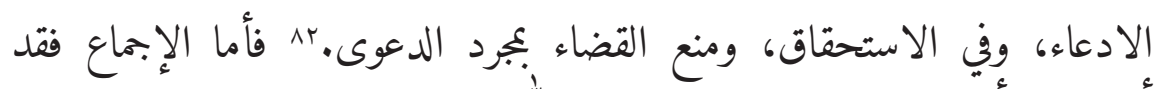

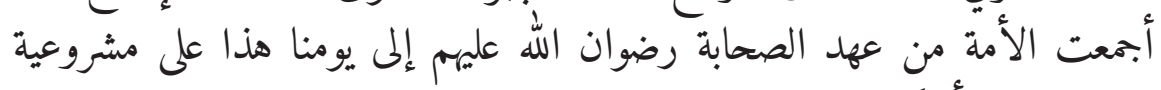

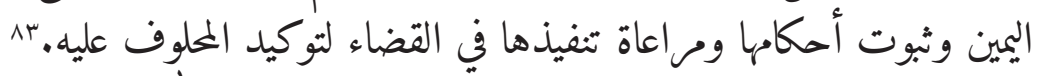

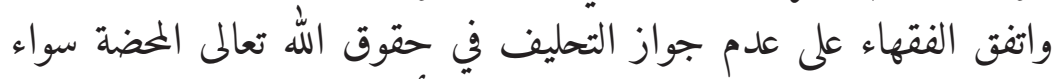

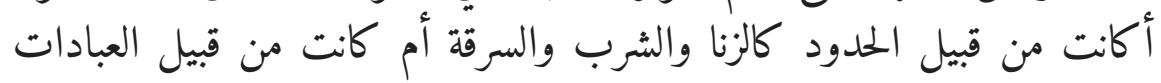

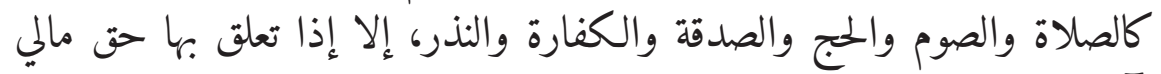

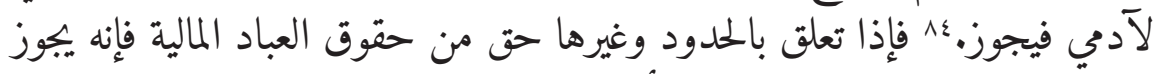

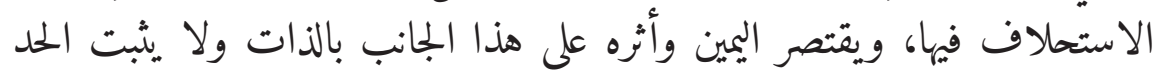

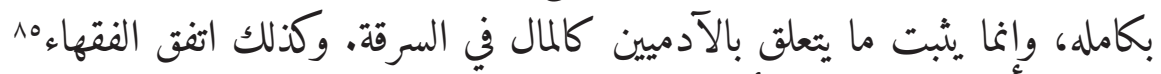

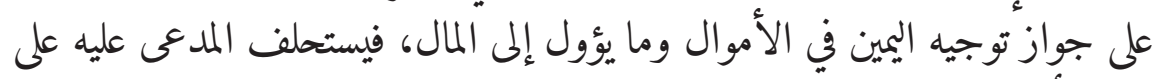
إثباتها أو نفيها.

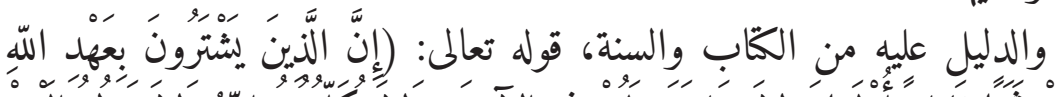

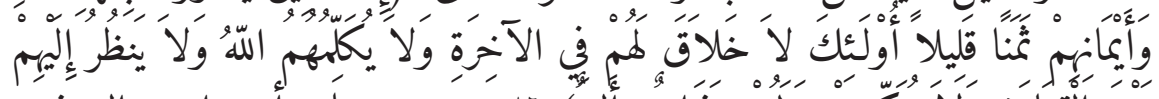

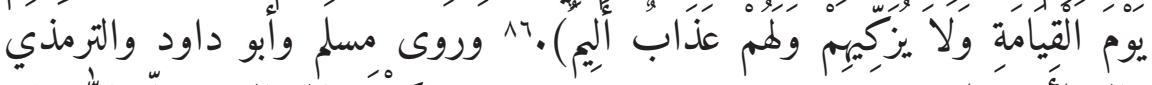

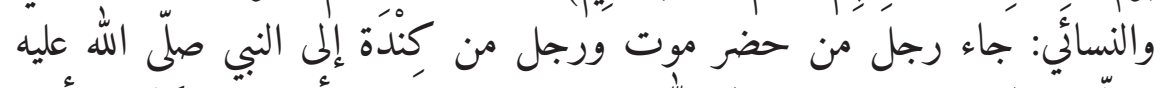

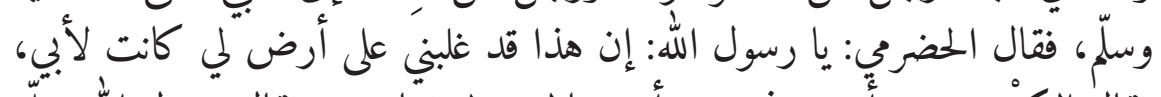

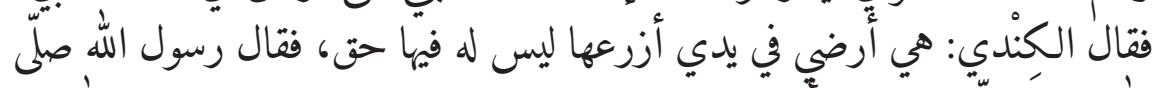

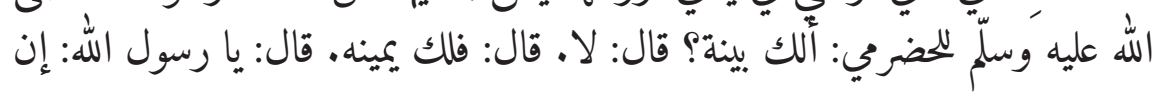

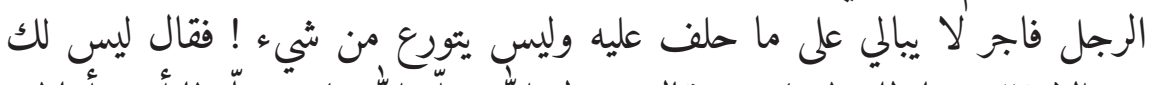

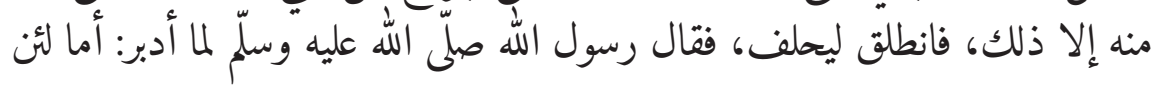

مصطفى, وسائل الإثبات في الشريعة الإسلامية والمعاملات المدنية والأحوال الشخصية.، ج ( )

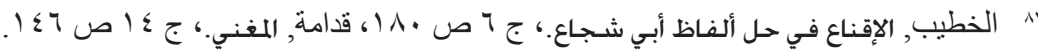

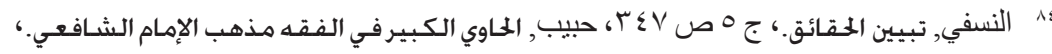

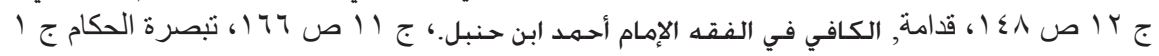
ص ص P

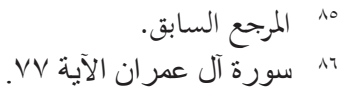




\section{حلف على ماله ليأ كله ظلها لَيَلَقِين الله وهو عنه مُعْرِض.}

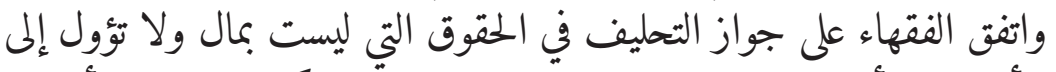

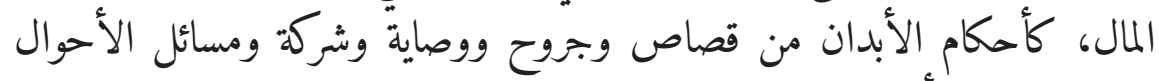

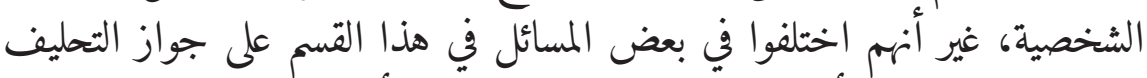

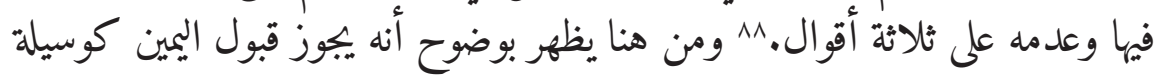

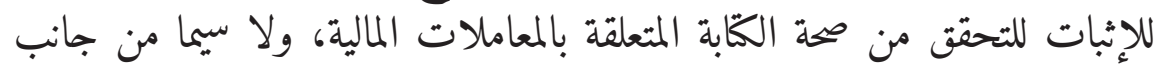

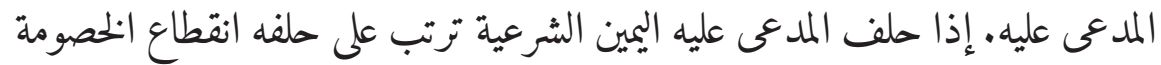

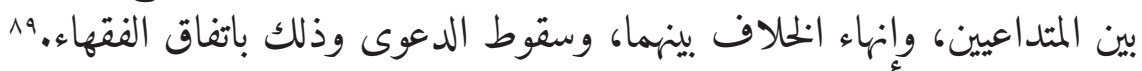

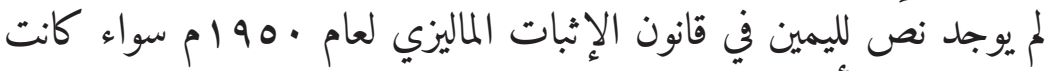

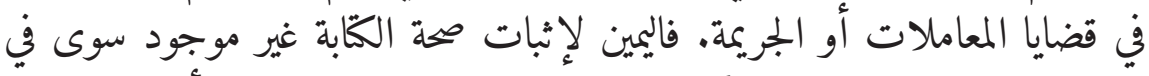

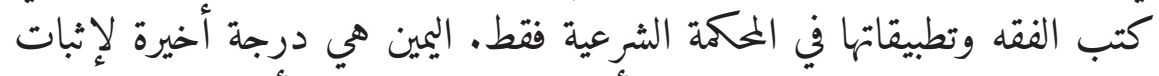

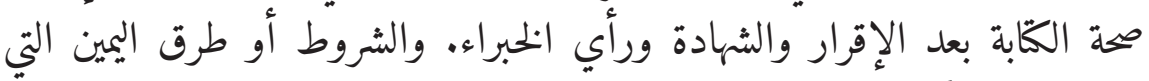

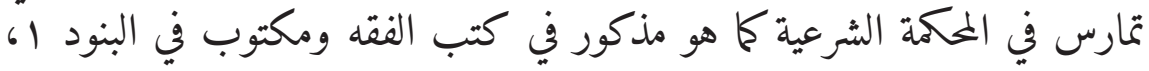

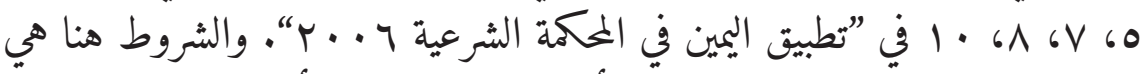

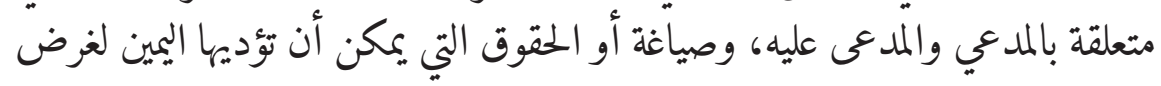

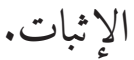

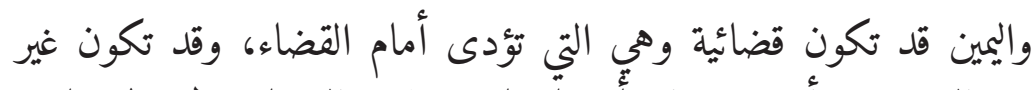

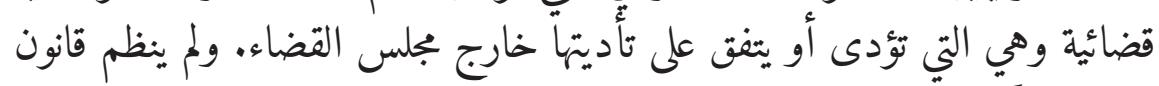

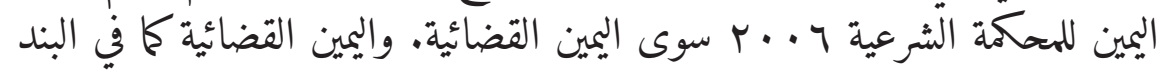

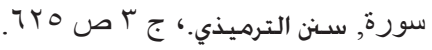

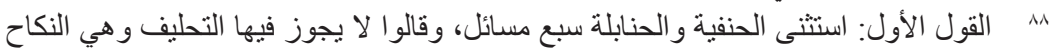

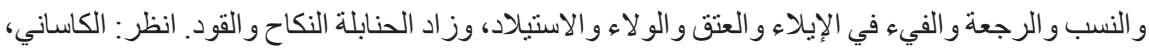

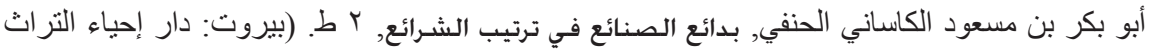

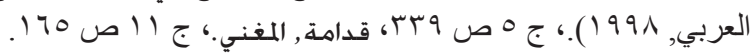

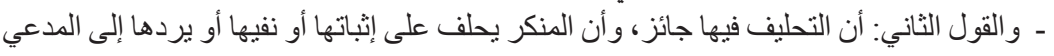

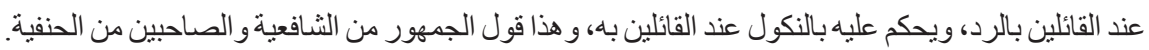

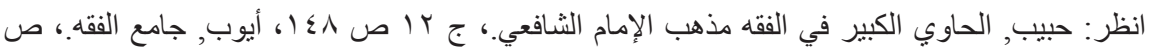

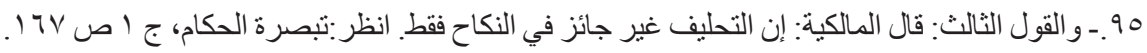

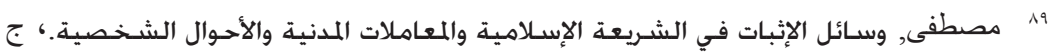




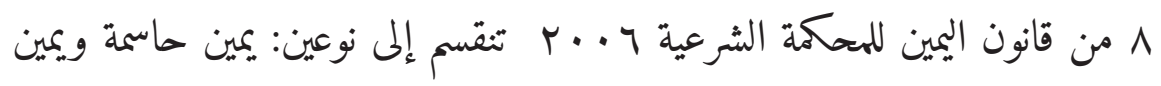
متممة.

تحقيق صحة الكَابة بالخبرة.

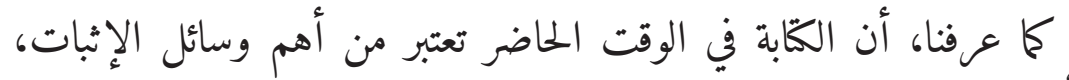

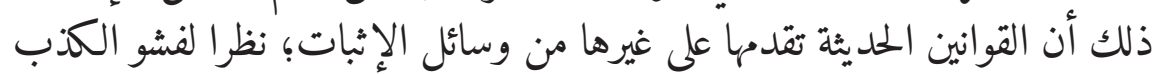

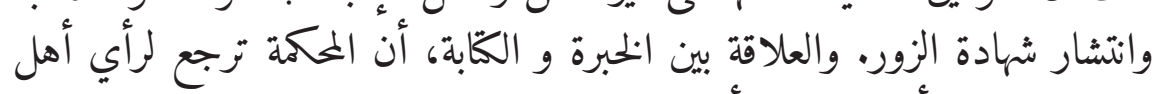

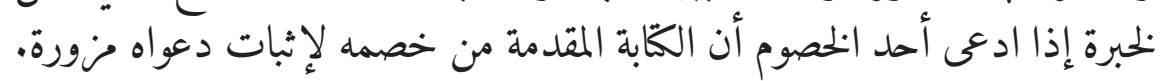

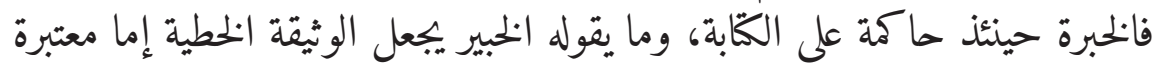

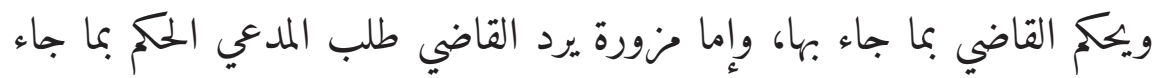
بالوثيقة.

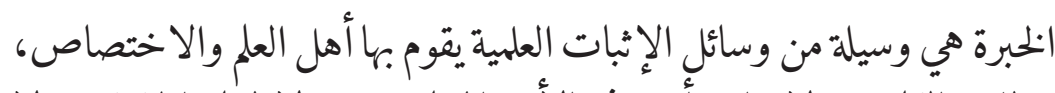

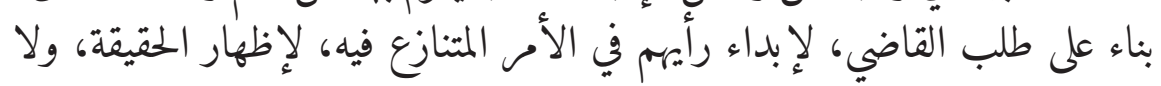

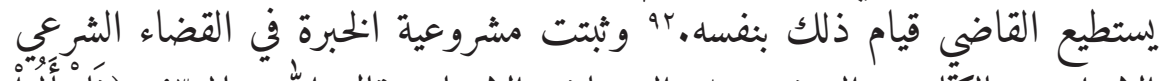

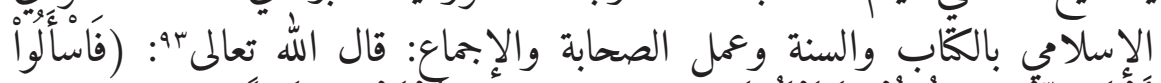

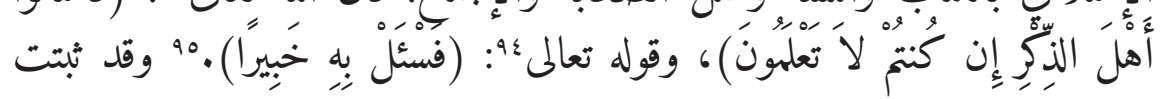

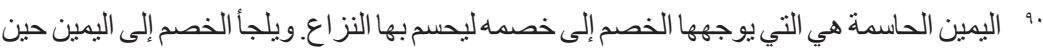

يعوزه الاليل الذي ينطلبه القانون، محتكما بذلك إلى ذمة خصمه وضميره، طالبا إليه أن يحلف ليحسم النزاع.

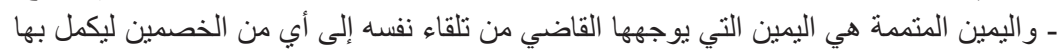

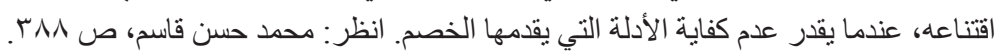

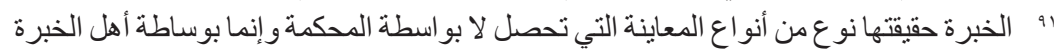

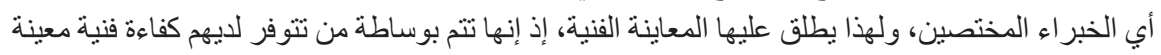

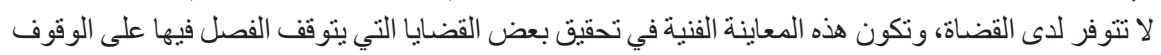

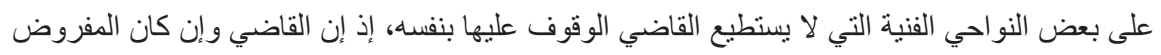

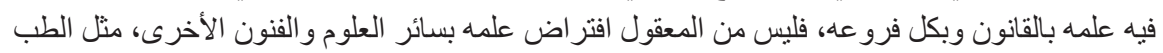

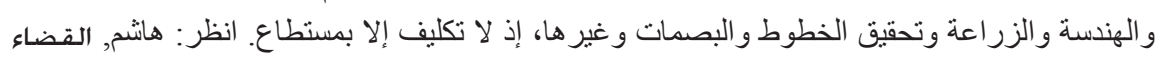

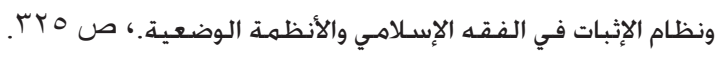

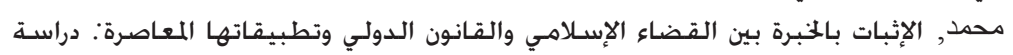

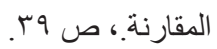

$$
\begin{aligned}
& \text { كو سورة النحل، الآية س؟ع. }
\end{aligned}
$$

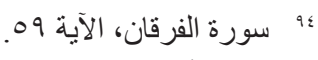

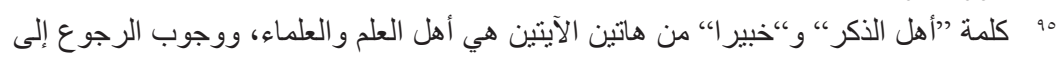


مشروعية الإثبات بالخبرة في السنة المشرفة ومنها: عن عائشة رضي الله عنها قالت:

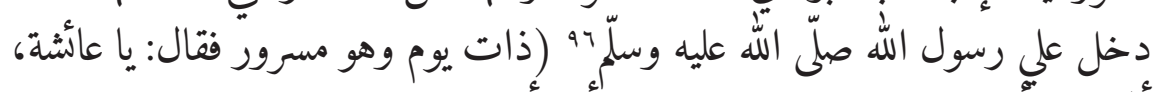

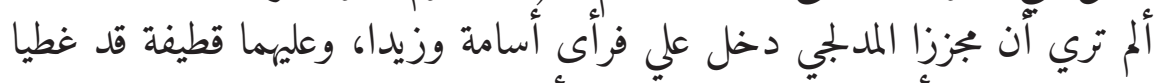

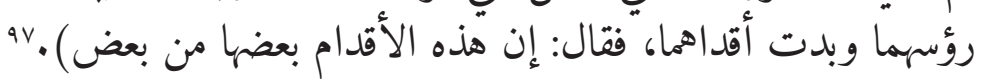

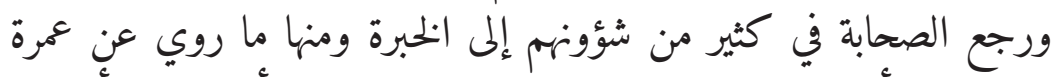

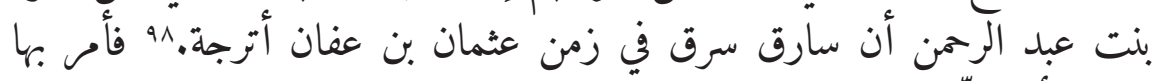

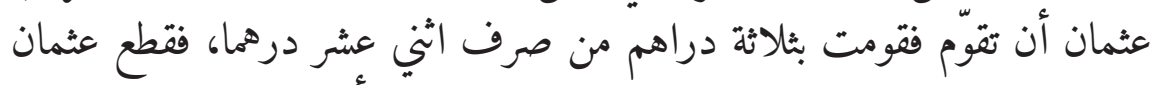

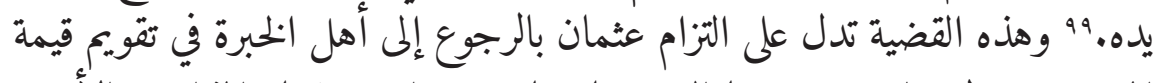

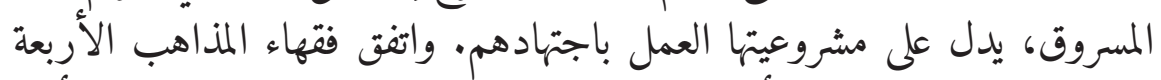

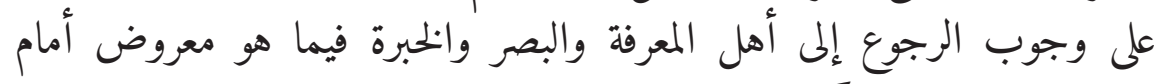

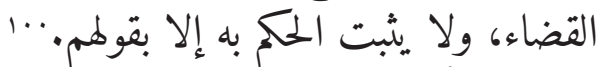

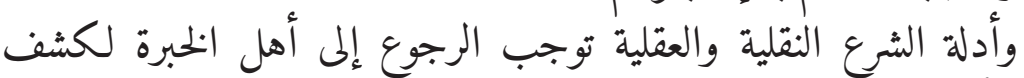

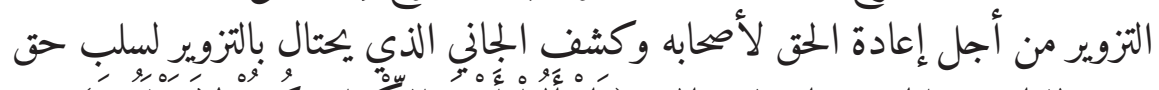

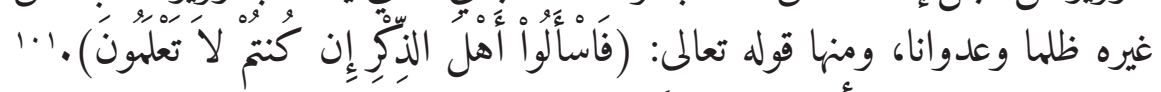

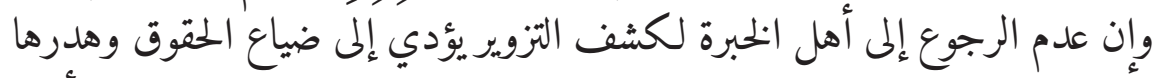

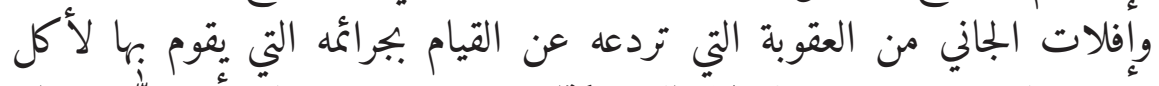
حقوق الغير، ويصبح عندئذ لا فائدة للكتابة وتوثيق الحقوق التيام التي أمر الله سبحانه

أهل العلم، والخبرة في كل فن من فنون العلم ، كل حسب علمه وخبرته. انظر : الأنصاري, الجـامع لأحكام

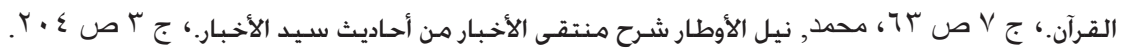

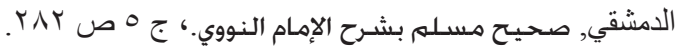

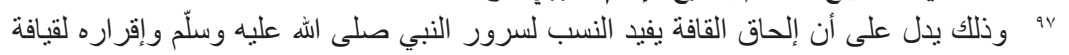
مجزز، فالنبي صلى الله عليه وسلّم لا يقر إلا على الحق ولا يسر إلا بالحق، وأن سرور النبي صلى الله عليه

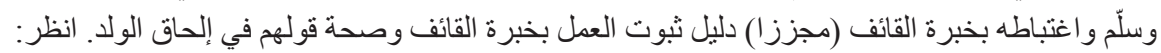

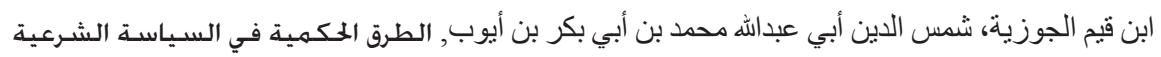

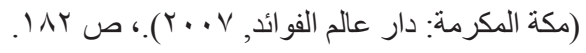

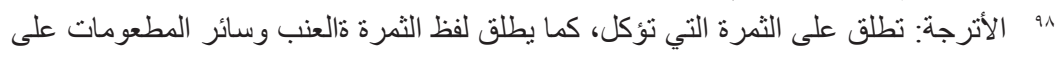

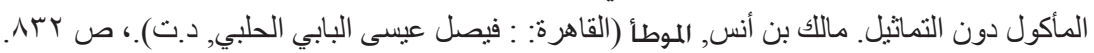

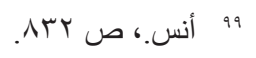

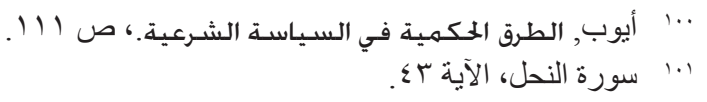




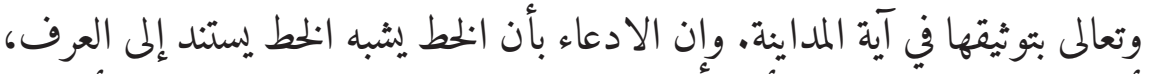

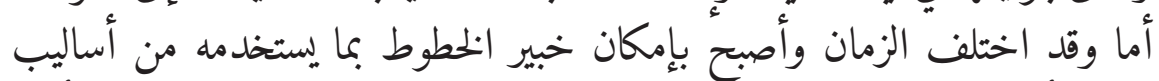

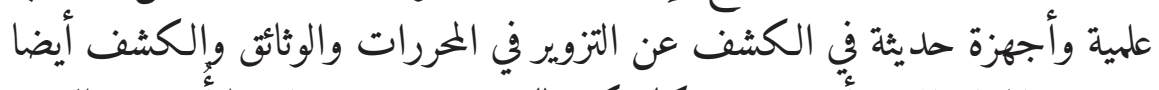

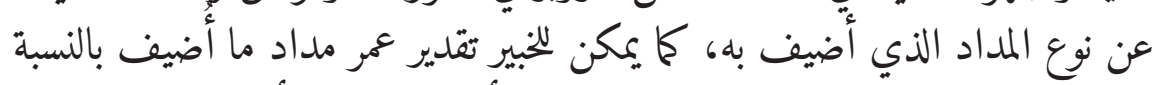

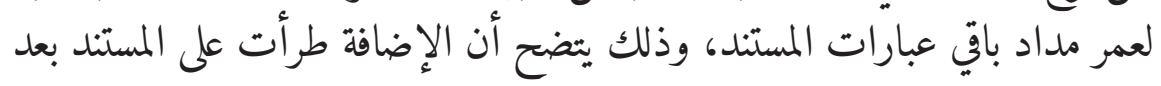

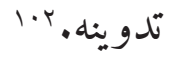

وبعد هذا التطور الكبير في علم الكشف عن الكما التزوير أصبح علما قائما بذاته

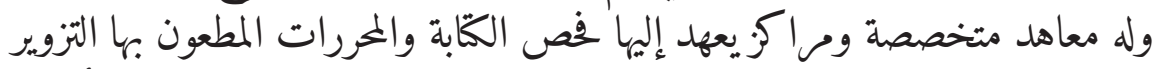

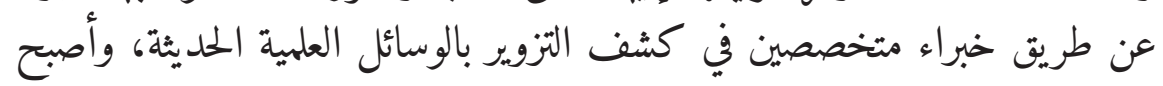

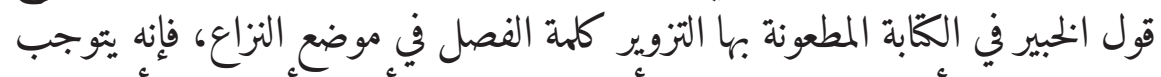

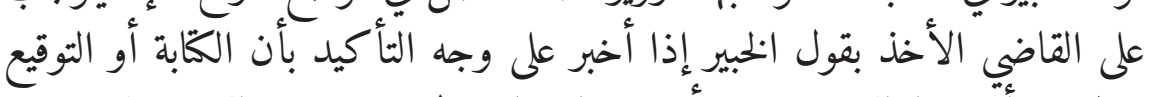

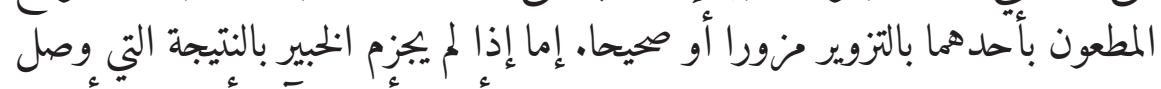

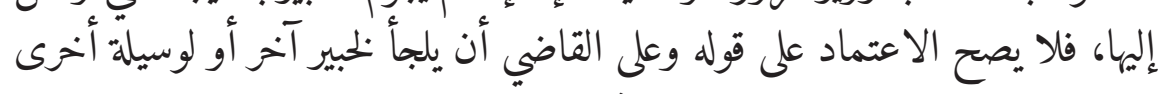

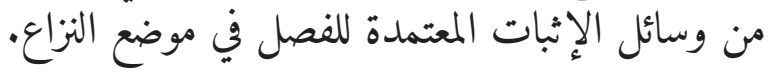

\section{ح. العمل بخبرة خبير الخطوط في كشف التزوير.}

$$
\text { 1. طرق كشف التزوير عند خبراء الخطوط. }
$$

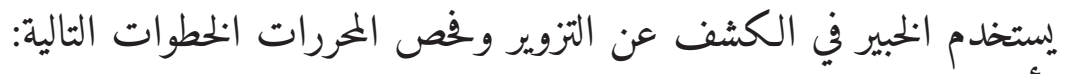

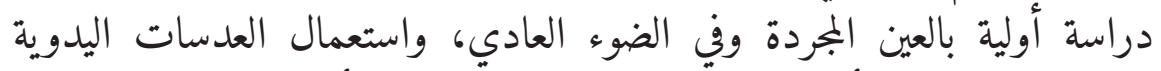

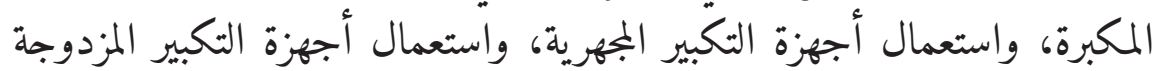

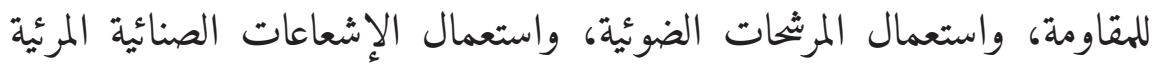

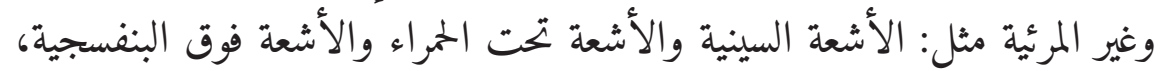

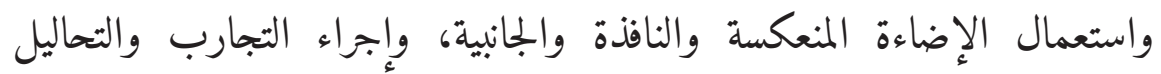

102 Lukman Abdul Mutalib et al., "Scientific Exegesis of al-Quran and Its Relevance in Dealing with Contemporary Issues: An Appraisal on the Book of 'alJawahir fi Tafsir al-Quran al-Karim”, International Journal of Recent Technology \& Engineering, vol. 8, no. 2S11 (2019), pp. 575-81. 


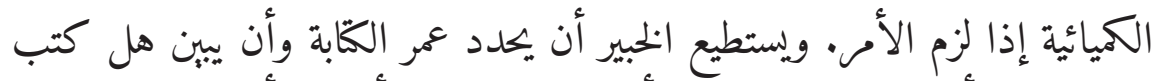

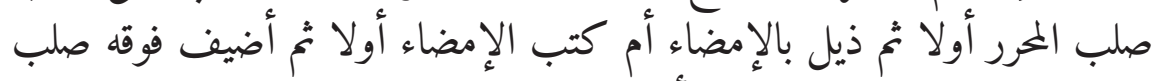

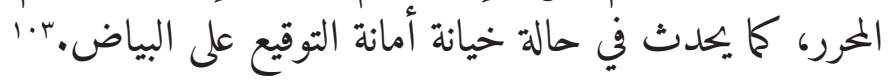

\section{r. طرق تحقيق الخط ومضاهاته عند خبراء الخطوط.}

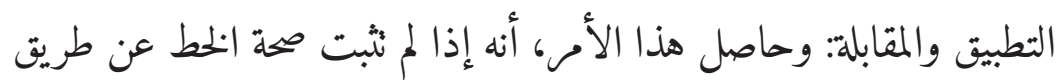

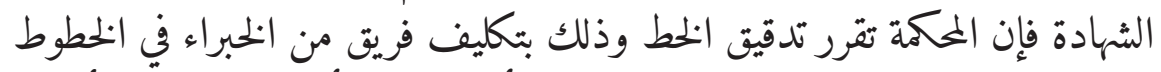

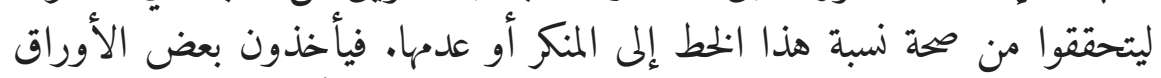

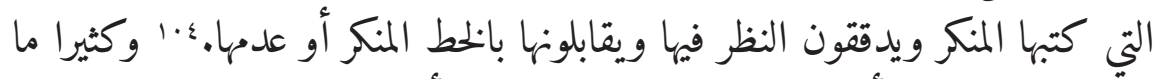

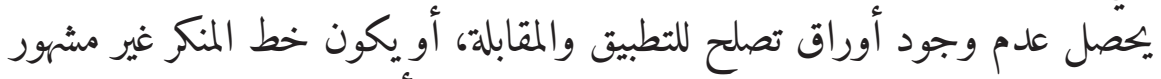

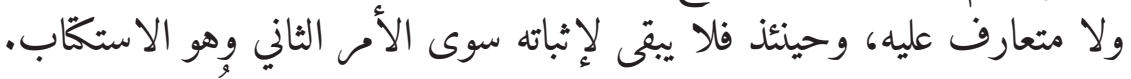

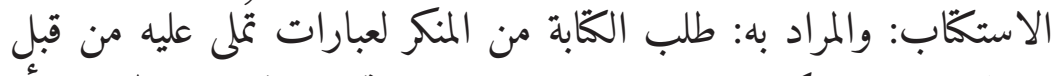

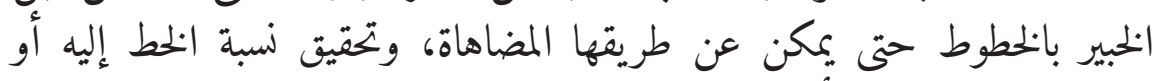

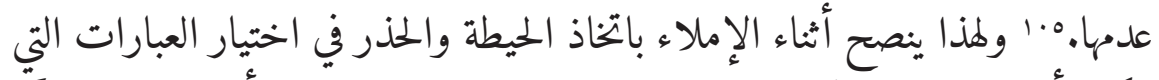

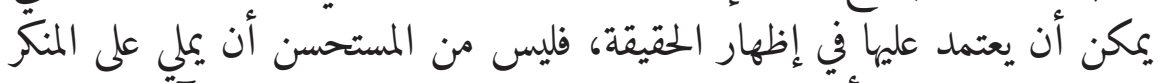

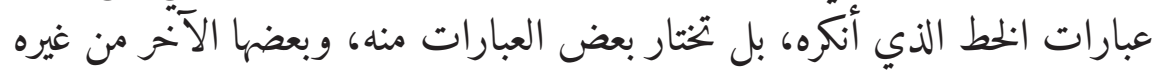

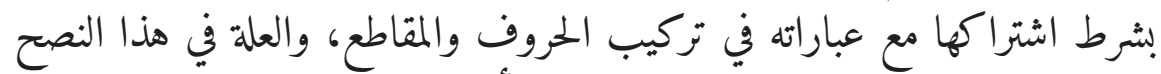

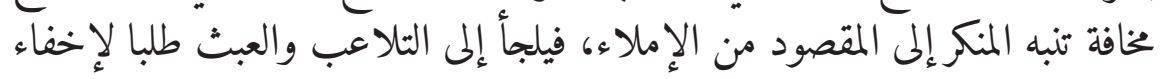
هذا ولا يفوت - في هذا لمقام - التنبيه على أن أصحاب الشأن قد صرحوا

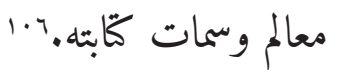

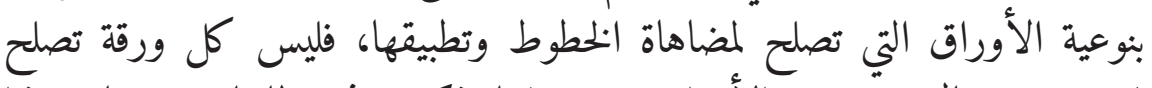

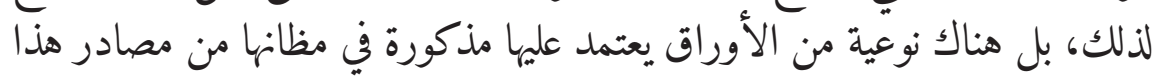

محمد, الإثبات بالخبرة بين القضاء الإسلامي والقانون الدولي وتطبيقاتها المعاصرة: دراسـة

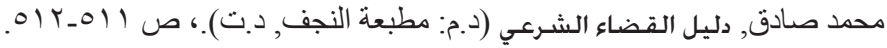

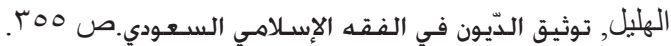

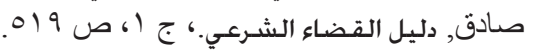




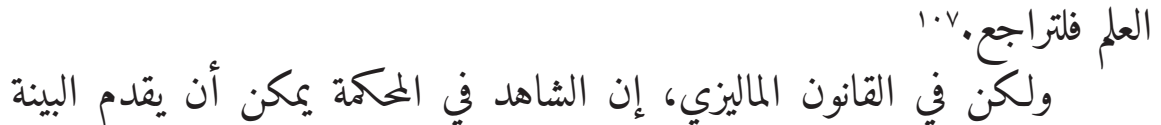

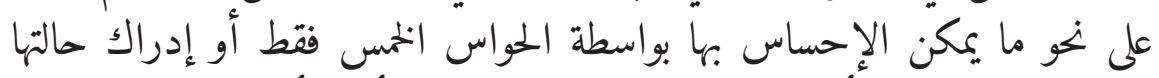

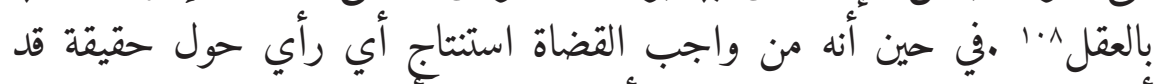

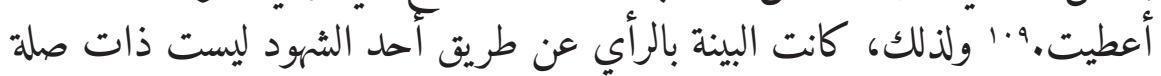

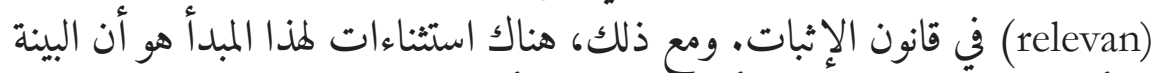

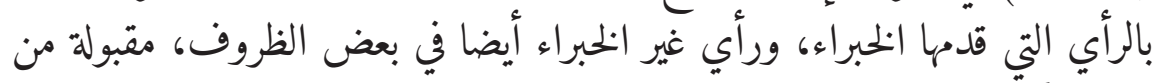

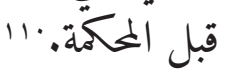

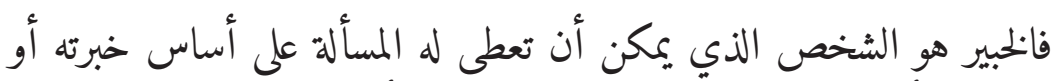
الخبرة.'"

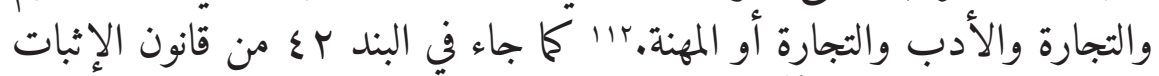

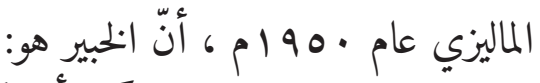

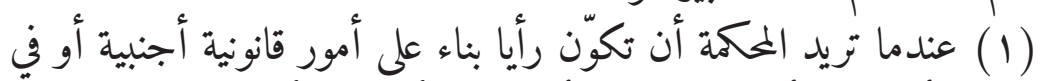

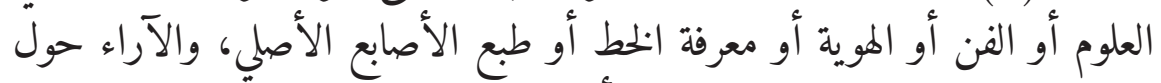

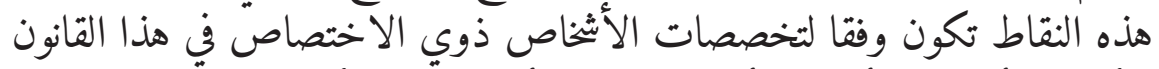

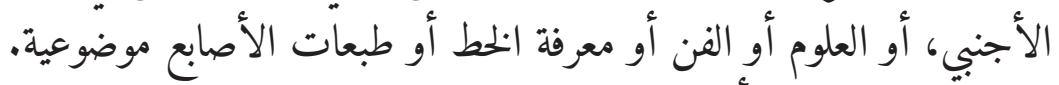

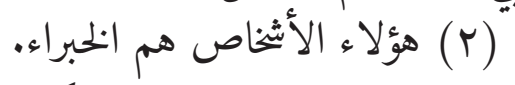

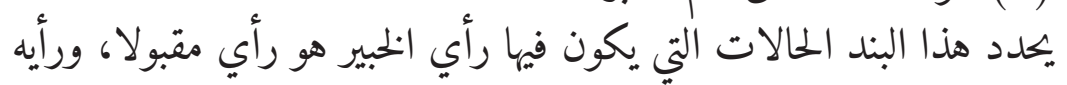

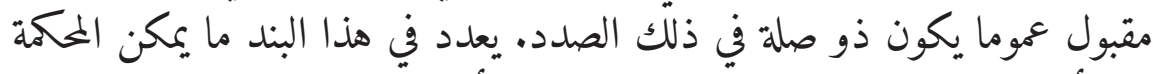

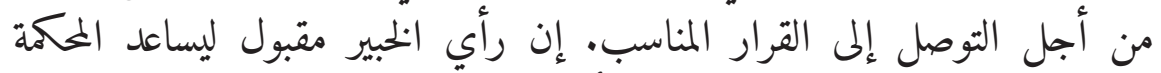

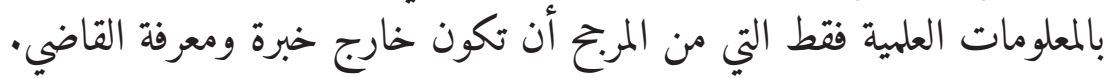

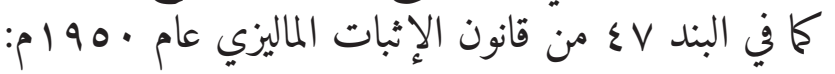

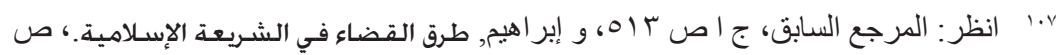

108 See Definition of 'Fact', Section 3 in Evidence Act 1950

109 M.C. Sarkar et al., Law of Evidence (New Delhi: Wadhwa and Company Law Publishers, 1993), p. 769.

110 See Wong Swee Chin v Public Prosecutor (1981) 1 MLJ 212

111 See Chandra sekaran \& Ors. v Public Prosecutor. (1971) 1 MLJ 153.

112 Sarkar et al., Law of Evidence, p. 770. 
عندما اقتضت لاتخاذ القرار في تحديد هوية الذي كتب أو وقّع على أية ألمائ

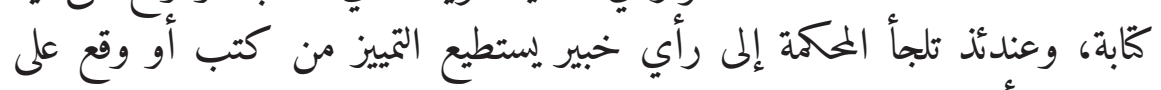
الكتابة، فرأيه مستلزم به عند الاقتضاء المثاء.

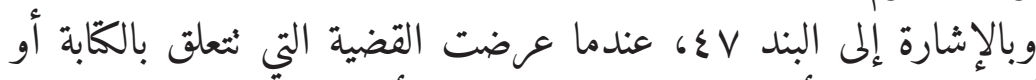

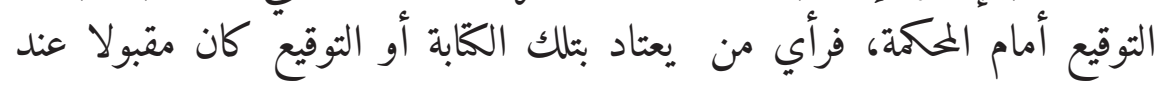

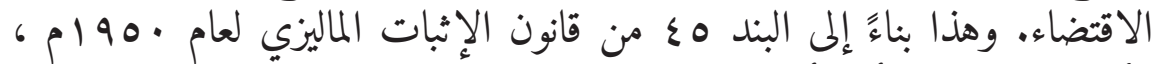

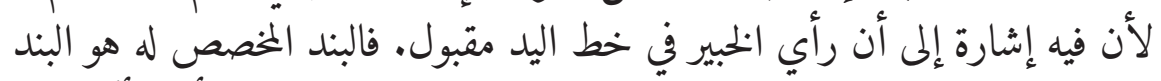

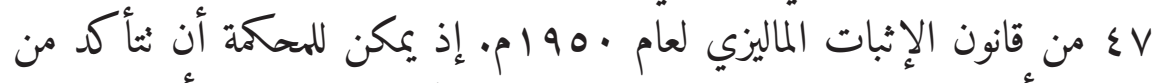

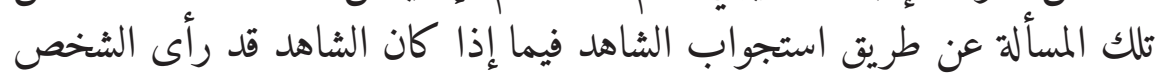

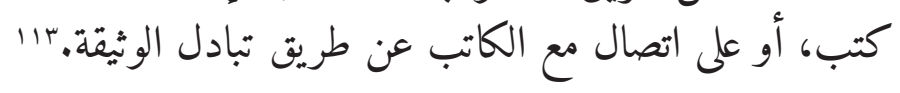

\section{ط. الخلاصة}

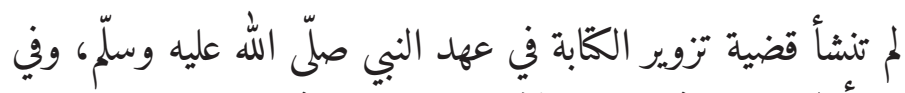

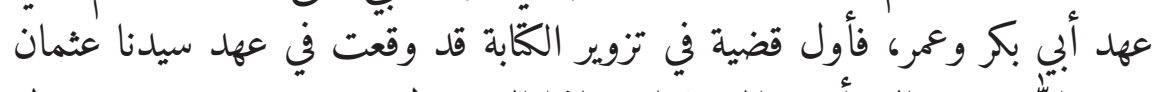

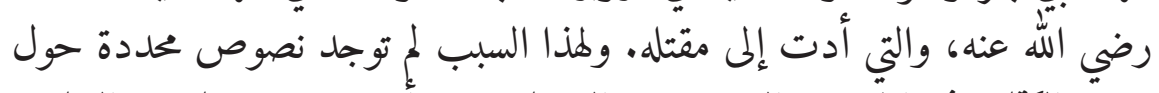

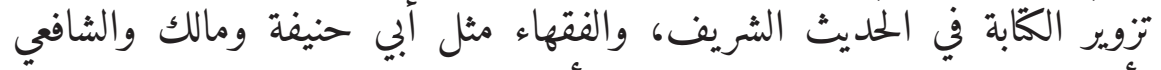

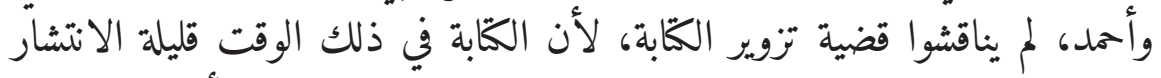

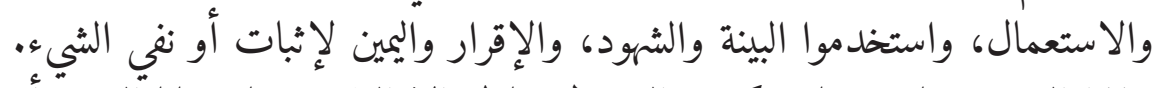

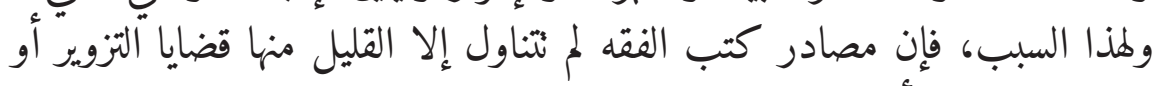

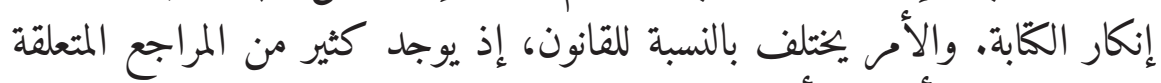

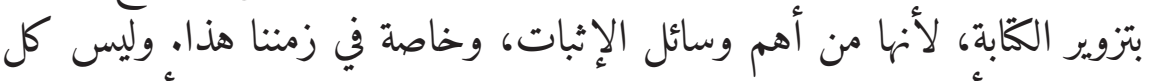

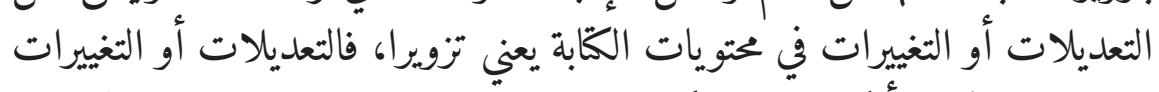

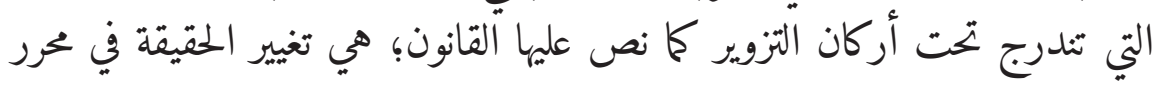

113 Yusoff, Pengenalan Undang-Undang Keterangan di Malaysia., p. 122; Wan Abdul Fattah Wan Ismail et al., "Understanding of Syariah Practitioners in Malaysia on Document Forgery”, Humanities \& Social Sciences Reviews, vol. 7, no. 6 (2019), pp. 349-55; Wan Abdul Fattah Wan Ismail et al., "The Reality on Application and Challenges of Closed-Circuit Television (CCTV) Images as Evidence in Shariah Criminal Cases in Malaysia”, Humanities \& Social Sciences Reviews, vol. 7, no. 6 (2019), pp. 356-61. 
بقصد الغش بطريقة من الطرق التي نص عليها القانون، بقصد جنائي، أو وقوع الضرر أو احتمال وقوعه.

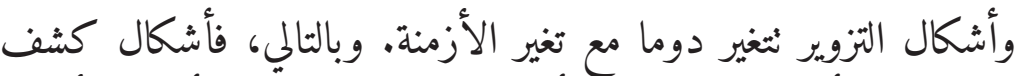

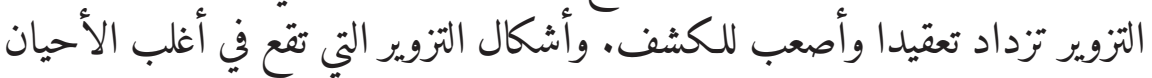

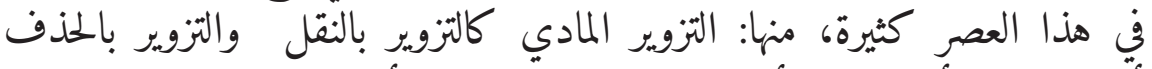

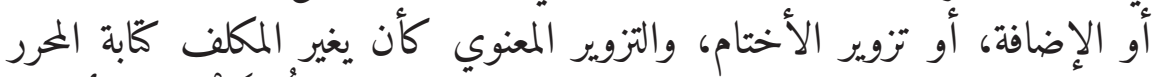

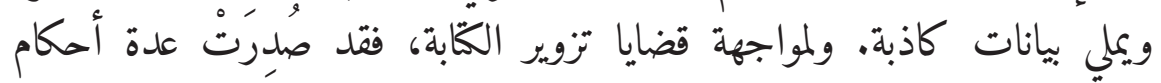

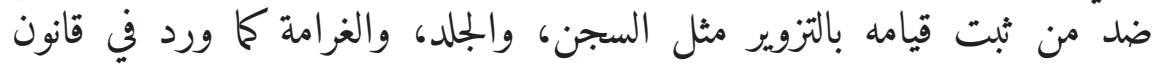

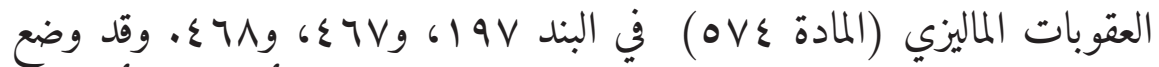

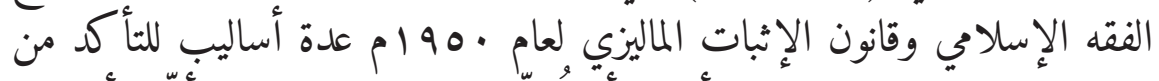

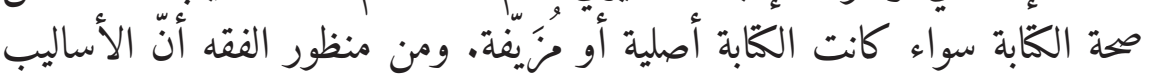

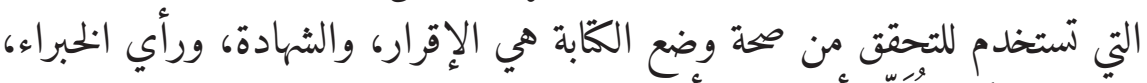

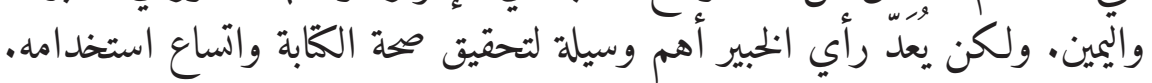

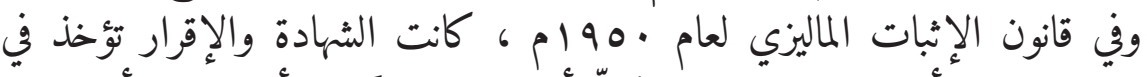

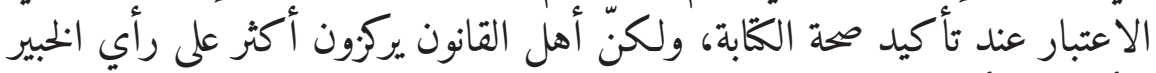

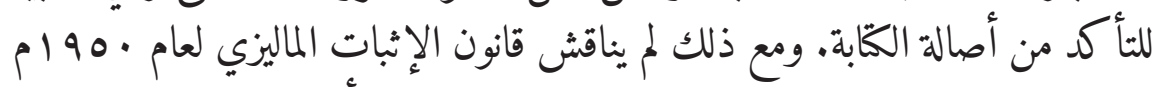

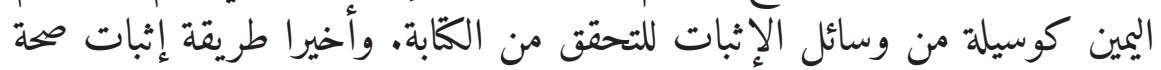

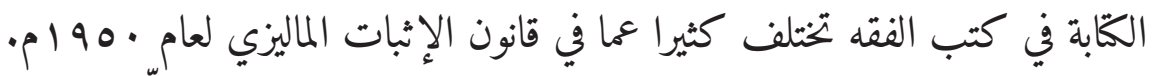

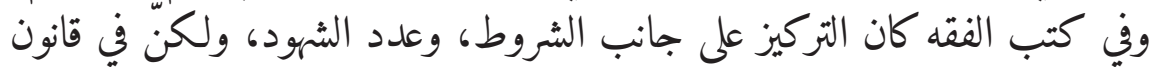

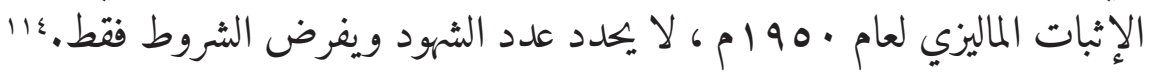

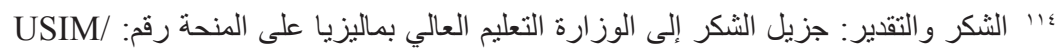

$0 . \mathrm{r} 19 / .00 \ldots \mathrm{r} / \mathrm{FRGS} / \mathrm{FSU}$ 


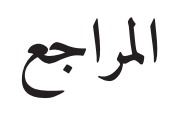

Baharuddin AS, Ahmad MH, Wan Ismail WAF, Mutalib LA, Wan Harun MA. "Catalysing Global Peace through the Strengthening of Forensic Science Application in Shari'ah Law”, Al-Shajarah, Special Issue Shariah and Law, (2019), pp. 77-103.

Baharuddin, A. S., "The Integration of Forensic Science Fundamentals and Al-Qarinah Towards Achieving Maqasid Al-Shari'ah", PhD. Dissertation, Johor: Universiti Teknologi Malaysia, 2017.

Ismail, Wan Abdul Fattah Wan et al., "Understanding of Syariah Practitioners in Malaysia on Document Forgery", Humanities \& Social Sciences Reviews, vol. 7, no. 6, 2019, pp. 349-55 [https://doi. org/10.18510/hssr.2019.7660].

----, "The Reality on Application and Challenges of Closed-Circuit Television (CCTV) Images as Evidence in Shariah Criminal Cases in Malaysia", Humanities \& Social Sciences Reviews, vol. 7, no. 6, 2019, pp. 356-61 [https://doi.org/10.18510/hssr.2019.7661].

Mohamed, Mohd Faisal et al., "Islamic Epistemology and Its Relations to Scientific Method in Islamic Law of Evidence", International Journal of Recent Technology \& Engineering, vol. 8, no. 3, 2019, pp. 4350-2.

Mutalib, Lukman Abdul et al., "Scientific Exegesis of al-Quran and Its Relevance in Dealing with Contemporary Issues: An Appraisal on the Book of 'al-Jawahir fi Tafsir al-Quran al-Karim", International Journal of Recent Technology \& Engineering, vol. 8, no. 2S11, 2019, pp. 575-81. [https://doi.org/10.35940/ijrte.B1089.0982S1119]

Osborn, Albert, Question Documents, 2nd edition, New York: Boyd Printing Company, 1943.

Paul, Augustine, Evidence: Practie and Procedure, Selangor: LexisNexis Malaysia, 2010.

Sarkar, M.C. et al., Law of Evidence, New Delhi: Wadhwa and Company Law Publishers, 1993.

Yusoff, Jal Zabdi Mohd., Pengenalan Undang-Undang Keterangan di Malaysia, Kuala Lumpur: Penerbit Universiti Malaya, 2008. 
آبادي, الشيرازي، أبو إسحاق إبراهيم بن علي بن يوسف الفيروز. المهذب في الفقه

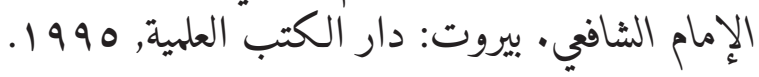

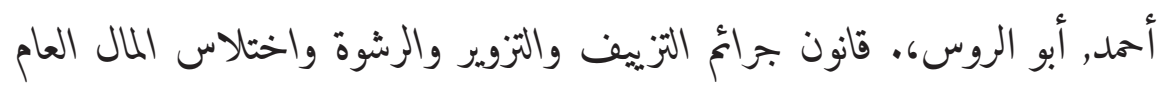

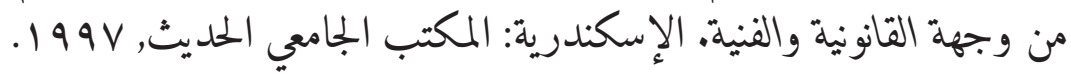
أفند, محمد علاء الدين. حاشية قرة عيون الأخيار تكملة رد المختار على الدر المختار

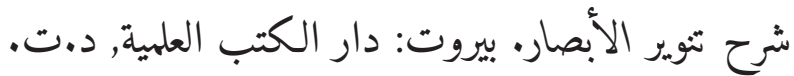

أمنو, البويطي، د. محمد بن بلعيد. الأوراق التجارية المعاصرة طبيعتها القانونية

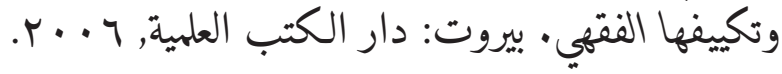

أمين, أحمد. شرح قانون العقوبات الأهلي. الإسكندرية: مطبعة دالر الكتب لمعبد

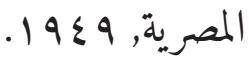

أنس, مالك بن. الموطأ. القاهرة : فيصل عيسى البابي الحلبي, د.ت.

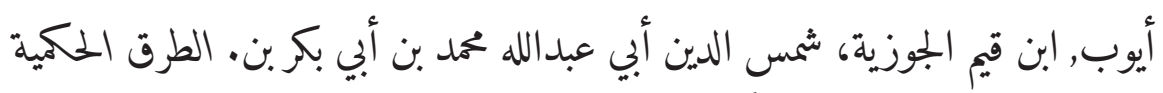

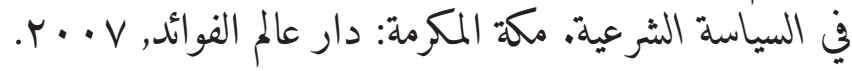

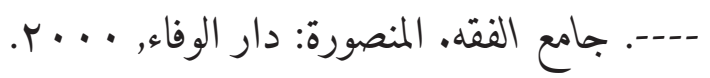

إبراهيم, أحمد إبراهيم. طرق القضاء في الشريعة الإسلامية. القاهرة: مطبعة السلفية, $.1 \mathrm{~T} \leqslant \mathrm{~V}$

إسماعيل, البخاري، أبو عبد الله محمد بن. صحيح البخاري. استنبول: دار سحنون, .1994

الأنصاري, ابن منظور، جمال الدين محمد بن مكرمّ. لسان العرب. بيروت: دار

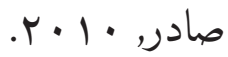

الأنصاري, القرطبي، أبو عبد الله محمد بن أحمد. الجامع لأحكام القرآن. بيروت: 
Wan Abdul Fattah Wan Ismail et al

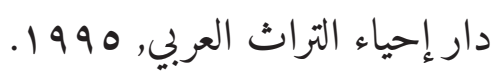

الإسلامية, وزارة الأوقاف والشؤون. الموسوعة الفقهية. ـ ط. الكويت: وزارة

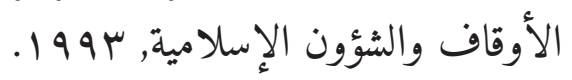

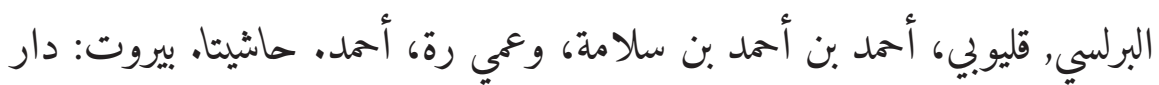

$$
\text { ألكتب العلمية, لو 1997. }
$$

البجاج, مسلم، أبو الحسين مسلم بن. صحيح مسلم: كتاب الحدود. استنبول: دار

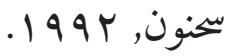

$$
\text { ---.- مختصر صيح مسلم. بيروت: مكتب الإسلامي, 191V. }
$$

الحكم, فوده، د.عبد. جرائم التزوير في المحرر الرسمية والعرفية في ضوء الفقه والقانون.

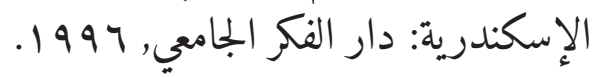

الحميد, الشواربي، الدكتور عبد. التزوير والتزييف مدنيا وجنائيا في ضوء الفقه والقضاء. الاسكندرية: منشاه المعارف, د.ت.

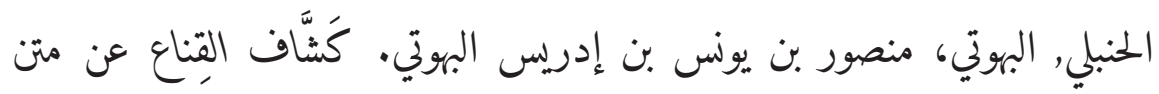

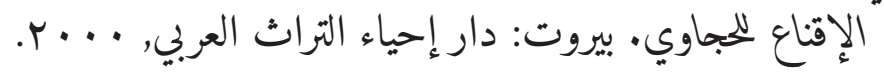

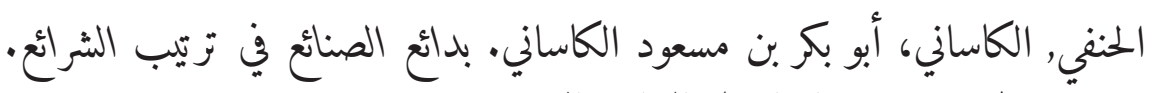

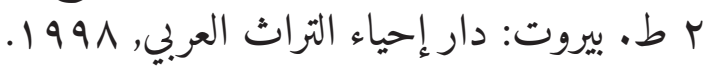

الخطيب, الشربيني، محمد بن محمد. الإقناع في حل ألفاظ أبي شجاع. بيروت: دار

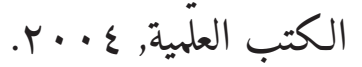

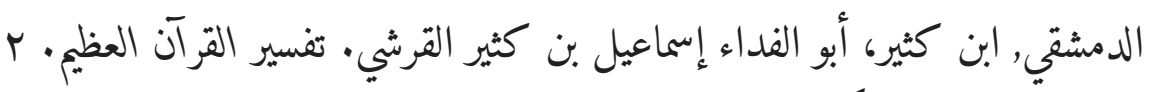
ط. دمشق: مكتبة دار الفيحاء, 199V.

الدمشقي, النووي، أبو زكريا يحيى بن شرف النووي. صحيح مسلم بشرح الإمام 


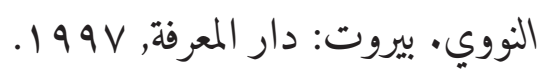

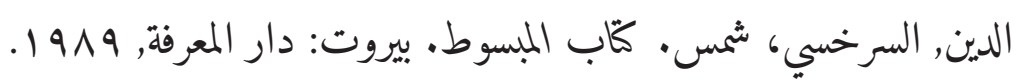
الرازي, الجصاص، الإمام أبو بكر أحمد. أحكام القرآن. بيروت: دار الفكر, به9 1. الزحيلي، وهبة. أصول الفقه الإسلامي. بيروت: دار الفكر المعاصر, 1919. الستار, فوزية عبد. شرح قانون العقوبات. القاهرة: دار الهضة العربية, 9^^1 1. السعيد, السعيد مصطفى. الأحكام العامة في قانون العقوبات: جرائ التزوير في

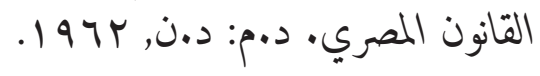

السيراسي, ابن الهمام الحنفي، محمد بن عبد الواحد. شرح فتح القّير. يروت: دار

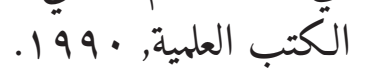

الصنهاجي, القرافي، أحمد بن إدريس بن عبد الرحم. الفروق. القاهرة: دار السلام, . . . I

العجيلي, الجمل، سليمان بن عمر بن منصور. حاشية الجمل على شرح المنهاج· يروت:

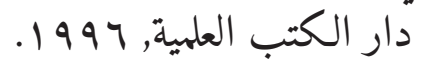

القادر, الرازي، الإمام بن أبي بكر بن عبد. مختار الصِّحاح. لبنان: مكتبة لبنان, .1917

القزويني, ابن ماجة، أبو عبد الله محد بن يزيد. سنن ابن ماجه. بيروت: دار الكتب

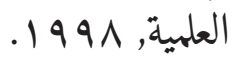

الله, ابن العربي، أبو بكر محد بن عبد. أحكام القرآن. عيسى البابي الحلبي وشركاه. $.197 \mathrm{~V}$

--... أحكام القرآن. عيسى البابي الحلبي وشركاه, 1997. 


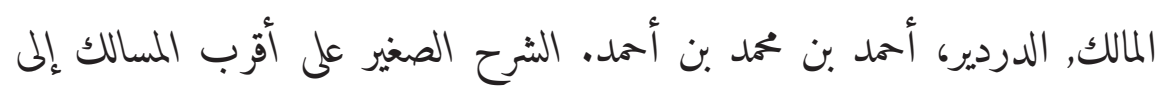

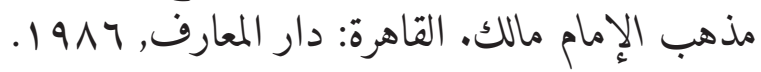

المقدسي, ابن مفلح، محمد بن مفلح. كتاب الفروع. بيروت: مؤسسة الرسالة, ب ـ . r.

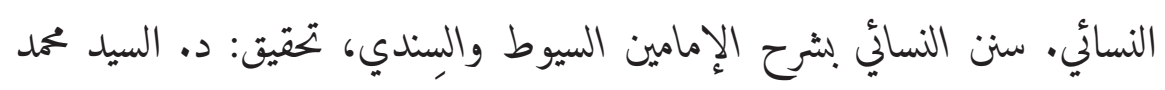

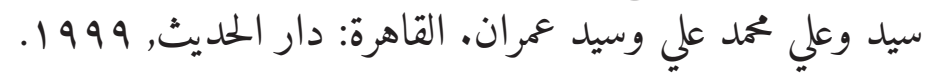

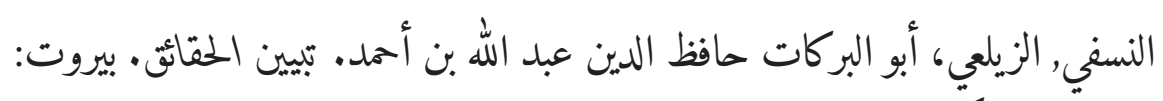

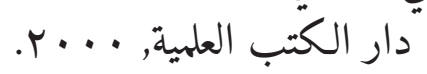

الهليل, صالح بن عثمان. توثيق الديوّن في الفقه الإسلاي السعودي. رياض:

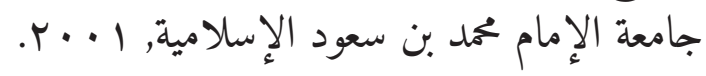

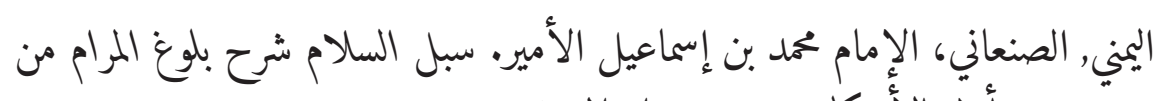

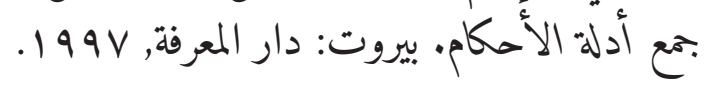

بيومى, ججازي، د. عبد الفتاح. الجريمة في عصر العولمة. الاسكندرية: دار الفكر

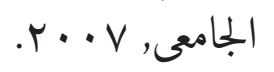

حبيب, الماوردي، أبو الحسن علي بن محمد بن. الحاوي الكبير في الفقه مذهب الفهب

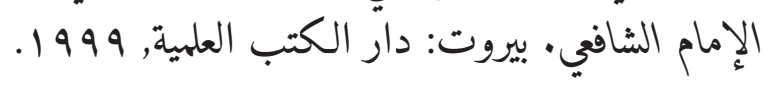

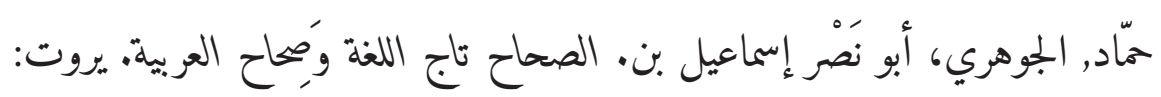

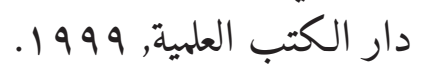

حمدان, عبد المطلب عبد الرزاق. الدعوى وإثباتها في الفقه الجنائي الإسلاي. الاسكندارية: دار الفكر الجامعي, V •..r.

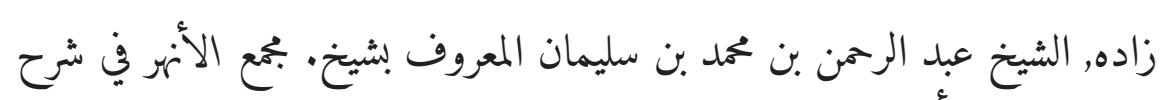

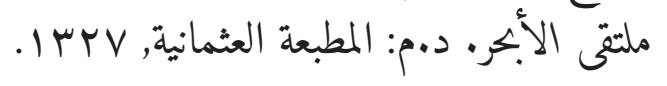


سالم, عبد المهيمن بكر. الوسيط في شرح قانون الجزاء الكويتي. ب ط. الكويت:

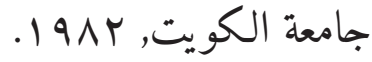

سهل, السرخسي، محمد بن أحمد بن أبي. أصول السرخسي. يروت: دار المعرفة,

سورة, الترهذي، محمد بن عيسى بن. سنن الترميذي. إستنبول: دار سحنون, ب99 ا. صادق, محمد. دليل القضاء الشرعي. د.م: مطبعة النجف, د.ت. عبّاس, العبودي، د. شرح أحكام الإثبات المدني. عمان: مكتبة دار الثقافة, .1999

عليّ, الشعراني، عبد الوهاب بن أحمد بن. كشف الغُمة عن جميع الأمة. بيروت:

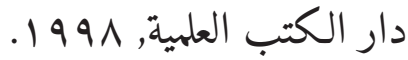

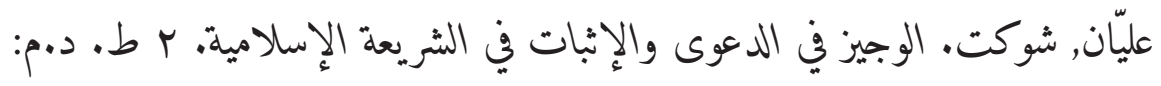

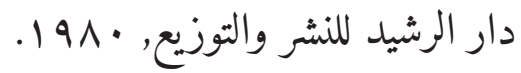

قدامة, ابن. الكافي في الفقه الإمام أحمد ابن حنبل. بيروت: دار الكتب العلمية, .$r \cdot .1$

- --_. المغني. القاهرة: دار الحديث, 1999. كامل, مأمون. تزوير الخطوط طرق ارتكابها ووسائل كشفه. r ط. ط. . القاهرة:

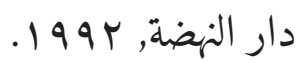

مبارك, الذيبيات، الدكتور غازي. الخبرة الفنية في إثبات التزوير في المستندات

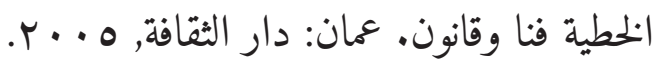

محمد, الشوكاني، محمد بن علي بن. نيل الأوطار شرح منتقى الأخبار من أحاديث

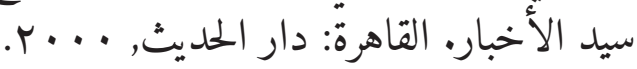


Wan Abdul Fattah Wan Ismail et al

محمد, الغزالي، أبو حامد محمد بن. المستصفى من علم الأصول. بيروت: مؤسسة

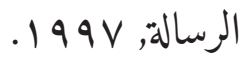

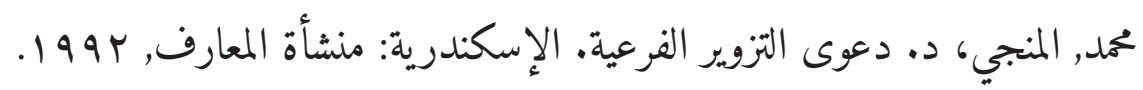
محمد, شنيور، عبد الناصر. الإثبات بالخبرة بين القضاء الإسلامي والقانون الدولي

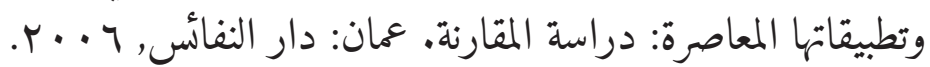

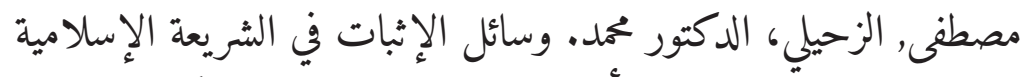

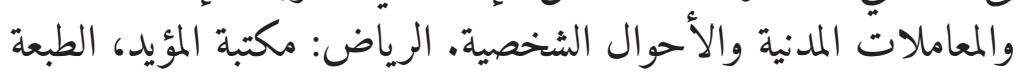

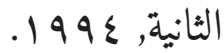

نظام, الشيخ. الفتاوى الهندية المعروفة بالفتاوى العالمكرية في مذهب أبي حنفية

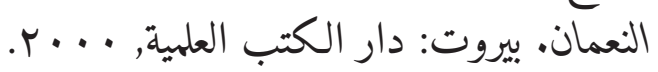

هاشم, محمود محمد. القضاء ونظام الإثبات في الفقه الإسلاي والأنظمة الوضعية.

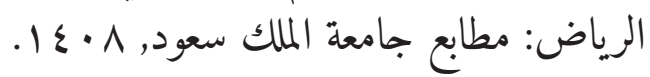

يعقب, الفيروز آبادي، مجد الدين محمد بن. القاموس الخيط. بيروت: دار الجيل, د.ت.

يوسف, عبد الحسيب عبد السلام. القاضي و البينة. كويت: مكتبة المعلاة, $.19 \wedge \mathrm{V}$ 